\title{
PESQUISA DE OPINIÃO PARA AVALIAR A VIABILIDADE DE IMPLANTAÇÃO DE UMA EMPRESA DE CONSULTORIA EM COMÉRCIO EXTERIOR NO RIO GRANDE DO NORTE
}

\author{
Cássia Mirella Muniz Cavalcante \\ Tecnóloga em Comércio Exterior, pelo Instituto Federal de Educação, Ciência e \\ Tecnologia do Rio Grande do Norte. E-mail: cassiamirella@gmail.com \\ João Maria Filgueira \\ Mestre em Engenharia de Produção; Especialista em Informática; Especialista em \\ Docência do Ensino Superior; Bacharel em Estatística. \\ E-mail: jmfilgueira@yahoo.com.br.
}

\section{RESUMO}

O presente trabalho monofigura tem por objetivo definir o perfil das empresas exportadoras do Estado do Rio Grande do Norte, a fim de analisar a necessidade de consultoria por essas empresas, como também analisar a inserção dos alunos de Comércio Exterior do Instituto Federal de Educação, Ciência e Tecnologia do Rio Grande do Norte, no mercado das empresas exportadoras. A análise foi realizada com a utilização de dados secundários, através de uma pesquisa de opinião, com aplicações de questionários junto a essas empresas, como também de pesquisa bibliográficas e em meio eletrônico. A população a ser estudada era composta 122 empresas exportadoras. Porém, com o escopo de obter melhores resultados, foi delineada uma amostra dessa população, que consistia, à priori, 59 empresas. Mas com o decorrer da pesquisa, esse número foi reduzido para 51 empresas, visto que, 5 dessas empresas haviam fechado, e outras 3 empresas exportavam por outros Estados. Logo, apenas 51 empresas passaram a compor a amostra da pesquisa. Das 51 empresas previstas para serem entrevistadas, 31 não responderam. Com isso, 20 empresas responderam ao questionário, o que somou uma taxa de retorno de 39,22\%, que é considerado excelente para uma pesquisa de opinião. Os resultados obtidos foram satisfatórios, uma vez que, permitiu atingir os objetivos iniciais da pesquisa. Foi permitido estudar o perfil das empresas, e analisar que as empresas do Estado conseguem manter-se economicamente equilibradas mesmo diante da crise mundial que afeta o mundo. Foi possível observar também a baixa colocação dos alunos de Comércio Exterior nessas empresas.

PALAVRAS-CHAVE: Empresas Exportadoras, Rio Grande do Norte, Consultoria, Alunos de Comércio Exterior, Pesquisa de Opinião.

\section{POLL TO ASSESS THE FEASIBILITY OF SETTING UP A BUSINESS IN CONSULTING INTERNATIONAL TRADE IN RIO GRANDE DO NORTE}

\begin{abstract}
This monographic study aims to define the profile of exporting companies in the state of Rio Grande do Norte, to examine the need for advice by these companies, but also examine the integration of students of Instituto Federal de Educação, Ciência e Tecnologia of the Rio Grande do Norte, in the market for exporting companies. The analysis was performed with the use of secondary data, through an opinion poll, together with applications of
\end{abstract}


questionnaires to these companies, as well as research literature and electronic media. The population being studied was composed 122 exporting companies. However, with the aim of obtaining better results, was presented a sample of the population, which was, in the begin, 59 companies. But over the course of search, this number was reduced to 51 companies, since 5 of these companies had closed, and other 3 companies exported by other States. Therefore, only 51 companies came to constitute the sample of the research. Of the 51 companies set to be interviewed, 31 did not respond. With this, 20 companies responded to the questionnaire, which a return rate of $39.22 \%$ which is considered excellent for an opinion poll. The results were satisfactory since, has achieved the initial objectives of the research. Was allowed to study the profile of companies, and examine the rule that companies can continue to be economically balanced despite the global crisis affecting the world. It was also possible to observe the low placement of students of Foreign Trade in those companies.

KEYWORDS: Exporting Companies, Rio Grande do Norte, Consulting, Students of Foreign Trade, Search Feedback.

\section{PESQUISA DE OPINIÃO PARA AVALIAR A VIABILIDADE DE IMPLANTAÇÃO DE UMA EMPRESA DE CONSULTORIA EM COMÉRCIO EXTERIOR NO RIO GRANDE DO NORTE}

\section{INTRODUÇÃO}

Para que uma empresa possa se inserir no mercado internacional, na maioria das vezes é preciso adaptar seus produtos ao mercado externo, tendo em vista as adequações obrigatórias dos países de destino, o que conseqüentemente gera um custo para a empresa, como modificações dos produtos, contratação de profissionais especializados e abertura de um setor de relações internacionais na empresa ou contratar empresas terceirizadas para consultoria em comércio internacional.

Para as grandes corporações abrir um departamento de relações internacionais pode parecer um pouco mais aceitável financeiramente, uma vez que, essas empresas podem manter um setor exclusivo para facilitar o processo. Já para as micro e pequenas empresas pode ser mais acessível contratar uma empresa de consultoria em comércio exterior para atender as expectativas da organização e baratear o procedimento. Porém todas as empresas, independentes do tamanho, estão sujeitas a necessitarem de suporte, visto as constantes modificações do mercado externo.

Segundo o Ministério de Desenvolvimento, Indústria e Comércio (MDIC) e a Secretaria de Comércio Exterior (SECEX), em 2008 o total de empresas exportadoras do Rio Grande do Norte somavam 122 empresas, e os valores de exportações variavam de empresas que exportavam até um milhão, à empresas que exportavam entre dez milhões e cinqüenta milhões.

A implantação de uma consultoria de comércio exterior no estado poderá incentivar as empresas que ainda não trabalham com o comércio exterior a se inserirem no mercado internacional, e às empresas que já exportam a aumentarem suas exportações, e conseqüentemente colaborar para o PIB (Produto Interno Bruto) da região. 
Com o objetivo de aumentar a participação do mercado potiguar no exterior, vários suportes de consultoria estão sendo prestados. Um grande diferencial é o Projeto Primeira Exportação, que está contando com a participação dos alunos do Instituto Federal De Educação, Ciência e Tecnologia Do Rio Grande Do Norte (IFRN), em parceria com instituições locais, como o Serviço de Apoio à Micro e Pequenas Empresas (SEBRAE/RN). E conta com empresas da região que nunca exportaram, ou que o fizeram pela última vez a mais de três anos atrás.

À fim de analisar as Empresas Exportadoras do Estados, e também para estudar o mercado profissional, principalmente dos alunos egressos do Curso Superior de Comércio Exterior, essa pesquisa mostrou a viabilidade de uma implantação de consultoria em comércio exterior para as empresas norte rio-grandenses, através de um estudo de mercado, onde foi realizada uma pesquisa de opinião junto às empresas exportadoras de Natal e região metropolitana.

Para isso, foi articulado o conceito de pesquisa de opinião com o conceito de técnicas estatísticas, para definir os entrevistados e analisar os dados da amostra. Foi também estudado o mercado norte rio-grandense a fim de descobrir a necessidade desses exportadores por consultoria e suporte técnico.

Tendo em vista essas empresas, que constitui um número reduzido de empresas que trabalham com o comércio internacional, e a excelente qualificação dos alunos egressos do Curso Superior de Tecnologia em Comércio Exterior do IFRN, não é comum observar a rápida colocação desses alunos no mercado.

Diante dessa conjuntura, surgem duas questões importantes: é viável a implantação de uma empresa de consultoria em Comércio Exterior no Estado do Rio Grande do Norte? E como os alunos de Comércio Exterior do IFRN estão inseridos no mercado?

Dessas forma, o objetivo geral da pesquisa é fazer um estudo de mercado para avaliar a viabilidade de implantação de uma empresa de consultoria em Comércio Exterior no Estado do Rio Grande do Norte e observar a colocação dos alunos de Comércio Exterior no mercado do RN.

E como objetivos específicos: Fazer uma pesquisa de opinião para definir o perfil das empresas exportadoras do Rio Grande do Norte; Estudar o mercado do Rio Grande do Norte em relação ao Comércio Exterior; Analisar a necessidade de suporte em consultoria para empresas exportadoras; Observar a colocação dos alunos de Comércio Exterior nas empresas exportadoras norte rio-grandenses.

A justificativa para a escolha do tema surgiu da necessidade de aplicar os conhecimentos adquiridos com o curso, através de um estudo de mercado, com o objetivo de desenvolver estratégias pertinentes para dar suporte às empresas exportadoras do Estado.

As exportações estão entre as principais propulsoras do crescimento de um país, pois são um instrumento de geração de divisas, empregos e renda. A preocupação em melhorar a participação do Estado na Balança Comercial Brasileira, descobrindo a principal dificuldade das empresas ao exportar, foi outro fator relevante para a escolha do tema, pois o número reduzido de empresas exportadoras no Estado, não é suficiente para destacar a economia da região, seja por baixo volume de produção para a exportação, e/ou pouco incentivos do governo às exportações da região. 
Dessa forma, esse trabalho surgiu da necessidade de contribuir para a expansão da base exportadora do Rio Grande do norte, uma vez que mostrará a real necessidade dessas empresas, buscando principalmente uma maior participação das micro e pequenas empresas que tem vocação exportadora, procurando entender os principais impasses encontrados por essas empresas e quais as necessidades de suporte que elas desejam.

Surgiu também da curiosidade de estudar a colocação dos alunos de Comércio Exterior no mercado de empresas exportadores do Rio Grande do Norte.

\section{PESQUISA DE OPINIÃO}

A pesquisa de opinião é um levantamento estatístico de uma amostra da opinião pública, ou seja, um conjunto de indivíduos que possam representar a população estudada, extrapolando as respostas para um grupo maior dentro de um intervalo de confiança. $\mathrm{Ou}$ seja, as pesquisas de opinião servem para fazer um estudo ou um levantamento, usando uma parte da população que se quer estudar (amostra) e a tornando como verdade para o restante da população de análise, por meio de questionários, com o objetivo de saber a opinião dessa população a cerca do assunto pesquisado.

A pesquisa de opinião tem como principais etapas a elaboração da amostra, a preparação do questionário, o planejamento e a realização do trabalho de campo, e a análise dos resultados.

Para iniciar uma pesquisa de opinião, é necessário definir a amostra que será objeto de estudo. Segundo (ALMEIDA, 2003, p.46), "a amostra deve ser uma réplica em pequena escala de toda a população." Ainda para Almeida (2003) a população pode constituir em pessoas, animais, células, ou coisas, onde se deseja obter as informações. Para Milone (2004), a população pode ser finita ou infinita, enquanto as amostras são sempre finitas.

É necessário definir muito bem a amostra da população que será estudada, para que a pesquisa obtenha os resultados esperados. Para isso, a estatística usa de dois conceitos importantes para aproximar os dados da amostra com a realidade da população: viés e precisão ou eficiência.

Viés é "um desvio consistente, repetido, e na mesma direção, da estatística amostral em relação ao parâmetro da população" (ALMEIDA, 2003, p. 49). Ou seja, é quando a pesquisa produz estimativas sistematicamente desviadas do valor verdadeiro - quanto mais viés, mais longe estão os dados da realidade.

De acordo com Mattar (1996), os erros que podem ocorrer nas pesquisas são de dois tipos: os erros amostrais e os erros não amostrais. Os erros amostrais ocorrem única e exclusivamente em função do número de elementos da amostra e do processo de seleção desses elementos. Já os erros não amostrais, são cometidos durante o processo de pesquisa que não sejam oriundos do tamanho e do processo de seleção da amostra.

A precisão ou eficiência ocorre quando os valores das amostras estão muito próximos do parâmetro da população. Isto é, quanto mais discrepantes entre si forem os resultados menos a precisão da pesquisa, e quanto mais próximos entre si, maior a precisão. Para 
Almeida (2003) quanto maior a amostra, maior será a precisão. Porém chega-se a um ponto em que aumentar a amostra a partir do aumento do número de entrevistas, não será satisfatório para a obtenção de ganhos substanciais adicionais na precisão.

As amostras podem ser de dois tipos: as probabilísticas e as não-probabilísticas. As amostras probabilísticas são aquelas em que todas as unidades de uma população (coisas, pessoas, animais.) têm chances iguais de participar da amostra. Já na não-probabilística não há essa chance, pois nesta os entrevistados serão escolhidos de acordo com algum critério que dependerá do objetivo da pesquisa (idade, sexo, renda salarial, profissão.).

Dentro das amostras probabilísticas, há algumas classes de amostras que serão ligeiramente descritas a seguir. Há a amostra probabilística simples, que é selecionada por sorteio, onde cada unidade tem a mesma chance de ser sorteada. Outra variante da amostra probabilística é a amostra sistemática, que, por meio do sorteio, deverão ser consideradas todas as unidades, do início ao fim da lista, onde o primeiro passo é embaralhar a lista de unidades da população a ser estudada, para que todos tenham a mesma probabilidade de serem escolhidos. A amostra estratificada é outra modalidade, e deve-se dividir a população em subconjuntos ou estratos, e dentro de cada estrato, se sorteia uma amostra aleatória, sistemática ou simples. E por último há a amostra por conglomerado, que permite fazer várias entrevistas em uma mesma unidade geográfica.

Existem alguns tipos de amostras também que derivam da amostra não-probabilística. A mais conhecida é a amostra por cotas, e também é muito utilizada no Brasil. Nesse tipo é necessário dividir a população a ser estudada em vários subgrupos - como homens e mulheres, jovens, adultos e idosos - e calcular o tamanho proporcional de cada subgrupo. Em seguida, define o número total de entrevista que deverão ser feitas para cada subgrupo. Depois de decidir qual tipo de amostra será utilizada na pesquisa de opinião, é preciso definir o tamanho dessa amostra, pois como dito anteriormente, ela sempre deve ser finita. Quando for delimitada, é necessário chamar a atenção para dois conceitos muito importantes neste tipo de pesquisa: a margem de erro e o intervalo de confiança.

A margem de erro, "diz o quão perto a estatística da amostra cai ou está em relação ao parâmetro da população" (ALMEIDA, 2003, p.58). E o intervalo de confiança "diz que percentual de todas as amostras possíveis satisfaz a margem de erro" (Almeida, 2003, p.58). A margem de erro e o intervalo de confiança estarão sempre conectados, pois em conjunto permitem fazer uma estimativa da pesquisa. Para definir o tamanho de uma amostra o coordenador terá que definir a margem de erro e que intervalo de confiança deseja.

O tamanho da amostra é definido antes de iniciar o trabalho de campo, e o coordenador da pesquisa é o responsável por isso. Quando se define o tamanho da amostra é preciso levar em consideração fatores como: custo, intervalo de confiança e margem de erro da pesquisa, além do tipo de análise que e deseja realizar.

A amostra probabilística é muito útil em pesquisa de mercado e acadêmicas. Acima de tudo, é a teoria da amostra probabilística que serve de base para avaliar os demais tipos de amostras.

Após definido a amostra, a segunda fase da pesquisa é na elaboração do questionário. É de suma importância a formulação do questionário, visto que a clareza das perguntas pode 
influenciar sobre o resultado da pesquisa. Formulações distintas de uma pergunta podem dar resultados diferentes.

Toda pesquisa é realizada para obter informações sobre algum tema ou questão. E quando se fala em questionário é necessário assumir uma função realista. Segundo (Milone, 2004, p. 7):

Não só há o fato dos questionários recolherem essencialmente o que os entrevistados acham conveniente declarar sobre seus comportamentos, práticas, situações e opiniões, como nada assegura ninguém que as questões foram interpretadas do mesmo modo por todos eles.

Ou seja, é mais fácil desviar as informações da realidade no questionário, onde os entrevistadores podem assumir uma função não parcial, na hora da entrevista, ou os entrevistados podem mentir sobre suas opiniões, se o questionário não for bem elaborado.

As perguntas de um questionário podem ser abertas ou fechadas. Perguntas abertas são aquelas em que os entrevistados podem expressar livremente sua opinião. As perguntas fechadas são aquelas que contêm questões com múltiplas escolhas. De acordo com Almeida (2003) a intenção é espontânea quando é obtida por meio de perguntas abertas, e é estimulada quando é através de perguntas fechadas, ou seja, com opções para resposta.

Nas perguntas abertas, a maior vantagem é que o entrevistado poderá dar sua própria opinião, e a desvantagem é o custo da codificação da pesquisa, visto que analisar cada resposta e sistematizá-las em pequenos subgrupos levará muito tempo e vai ser preciso de codificadores bem treinados e experientes. As principais vantagens das perguntas fechadas são a uniformização das respostas e a facilidade de análise dos dados, e a principal desvantagem é a estruturação das respostas.

Na hora da elaboração do questionário, para Almeida (2003) é fundamental levar em consideração alguns fatores como: elaborar perguntas claras, utilizar uma redação balanceada, evitar coloquialismo, jargões ou lugares-comum, levar em consideração o nível de instrução formal dos entrevistados, elaborar perguntas e estruturar o questionário de modo a evitar as respostas socialmente aceitáveis, testar as opções de respostas das perguntas fechadas e avaliar que perguntas inserir no início e no fim do questionário.

Após definir a amostra da população, e elaborar o questionário, parte-se para o trabalho de campo, que exige muita qualificação e treinamento para que realizem trabalho de boa qualidade. Pois como afirma Almeida (2003, p. 101) "pouco adianta ter uma amostra tecnicamente perfeita, um questionário bem elaborado e adequadamente pré-testado, se o trabalho de campo é de má qualidade".

As equipes de campo são compostas por dois tipos de profissionais: supervisores e entrevistadores. Os supervisores fiscalizam o trabalho, enquanto os entrevistadores realizam as entrevistas. Os dois tipos de profissionais recebem treinamento qualificado de acordo com a pesquisa que será realizada.

No trabalho de campo os entrevistadores e os supervisores podem trabalhar juntos ou separadamente. Eles trabalham juntos quando enquanto os entrevistadores realizam a entrevista, o supervisor acompanha e confere os aspectos do entrevistador. E trabalham separados quando os entrevistadores são designados a realizar certo número de entrevistas, com local e data definidos, e o supervisor monitora diariamente ou a cada dois dias.

Um passo fundamental na realização da pesquisa de campo é o treinamento dos profissionais que executarão o trabalho de campo. Entrevistadores e supervisores devem 
ser submetidos ao mesmo treinamento, com apenas uma diferença: os supervisores precisam receber treinamento específico de supervisão.

Uma das preocupações na hora da pesquisa de campo é a fraude. Para Almeida (2003) "a fraude é uma ação voluntária, eventualmente premeditada, que os entrevistadores empreendem a fim de trabalhar menos, mas receber o mesmo pagamento ao final do trabalho". As fraudes são comuns em situações em que o entrevistador não tenha estímulo para realizar o trabalho. E existe uma única maneira de combater a fraude em pesquisa: controlar e fiscalizar permanentemente entrevistadores e supervisores.

A qualidade do trabalho de campo vai depender exclusivamente da realização correta das entrevistas. $\mathrm{O}$ entrevistado precisa estar à vontade para responder as perguntas e jamais se sentir forçado a dar determinada resposta. $\mathrm{O}$ objetivo do entrevistador é apenas um: extrair do entrevistado a resposta mais fiel possível e registrar seu modo de pensar acerca do assunto pesquisado.

Concluindo a coleta dos dados, a próxima fase é a análise dos resultados colhidos. É importante saber que antes de elaborar a amostra e o questionário, o pesquisador precisa saber exatamente as respostas que se quer atingir com a pesquisa, para que na análise o pesquisador não tenha dificuldade em extrair os dados necessários.

Toda pesquisa deve ter uma delimitação do que será pesquisado e dos resultados que se deseja obter, é o que Almeida (2003) chama de "a delimitação do escopo da análise". Uma afirmação óbvia, mas que segundo ele muitas vezes esquecida por usuário de pesquisa e seus críticos.

Para dar continuidade a este assunto, é preciso compreender o que Almeida (2003) considera de vocabulário básico sobre alguns conceitos que fazem parte da análise dos dados:

- Variável: cada característica das unidades sobre as quais se quer obter informações. (Por exemplo: a variável gênero pode assumir os valores masculino ou feminino).

- $\quad$ Frequiência simples: é a contagem bruta de quantas vezes um determinado fenômeno ocorre.

- $\quad$ Freqüência relativa ou proporção: é a ocorrência relativa de um determinado fenômeno, ou seja, sua ocorrência em relação ao total de casos.

- Relação entre duas variáveis: toda análise visa explicar. Assim, há a variável denominada "variável independente" ou "explicativa", que é a causa de um fenômeno, e a variável dependente, que é a variável explicada ou a conseqüência.

Toda análise deve ser idealizada antes da elaboração do questionário e da amostra, para atingir o objetivo que se deseja. Pois quanto mais o pesquisador souber das variáveis relevantes para a pesquisa, melhor será a análise e os resultados.

Os índices também são ferramentas importantes na análise dos dados, pois com eles é possível descrever e explicar o comportamento dos indivíduos. Segundo (Almeida 2003, p. 132) "um índice é um indicador, em geral composto por mais de uma variável, que serve para mensurar algum conceito". Para (Milone, 2004, p. 453) "entende-se por índice a variação relativa na variável de interesse". 
$\mathrm{Na}$ elaboração de um índice o primeiro passo é definir o que se deseja mensurar. Em seguida é escolher as variáveis que formarão o índice. Seja qual for a variável, ela deve fornecer uma medição válida, ou seja, estar de acordo com o que se deseja medir. Os índices podem e devem ser formados por mais de duas perguntas.

$\mathrm{Na}$ análise dos resultados pode ocorrer a variância de resultados entre as pesquisas, como o próprio nome já diz, é diferença de resultados que pode dar entre uma e outra pesquisa. Com isto, a tendência - definição importante para a estatística, é algo que pode ser captado comparando-se as respostas a uma determinada pergunta, repetida em várias perguntas ao longo do tempo. Algo só pode ser considerado como tendência a partir da terceira pesquisa realizada. E por último, e não menos importante, a definição de margem de erro, que mede o quanto para mais ou para menos os resultados obtidos podem variar. Quanto menor for a margem de erro, mais confiável se torna a pesquisa.

Dessa forma, as pesquisas de opinião são muito utilizadas quando se quer saber o ponto de vista da população a cerca de determinado assunto. Se todas as fases da pesquisa forem realizadas por profissionais responsáveis e treinados, pode-se fazer um bom trabalho e atingir um resultado de plena satisfação.

\section{ESTATÍSTICA}

Esta seção trata da importância da estatística, bem como procura explicar as principais definições de alguns elementos importantes utilizados no presente trabalho, e algumas técnicas utilizadas.

\section{IMPORTÂNCIA DA ESTATÍSTICA}

O termo estatística surge da expressão em latim statisticum collegium palestra sobre os assuntos do Estado, de onde surgiu a palavra em língua italiana statista, que significa "homem de estado", ou político, e a palavra alemã Statistik, designando a análise de dados sobre o Estado. Aparece como vocabulário na Enciclopédia Britânica em 1797, e adquiriu um significado de coleta e classificação de dados, no início do século 19.

Para Triola (1998, p. 2) estatística "é uma coleção de métodos para planejar experimentos, obter dados e organizá-los, resumí-los, analisálos, interpretá-los e deles extrair conclusões". Já para Milone (2004, p. 3) "as múltiplas facetas da estatística dificultam conceituá-la de modo satisfatoriamente preciso".

Segundo (FONSECA; MARTINS, 1996, p. 15) "todas as vezes em que se estudam fenômenos de observação, cumpre-se distinguir o próprio fenômeno e o modelo matemático (determinístico ou probabilístico) que melhor o explique".

Para entender estatística, vale relembrar dois conceitos básicos, que já foram citados anteriormente: população, amostra e parâmetro. A população é uma coleção completa de todos os elementos a serem analisados. A amostra é uma pequena parte da população que 
será estudada, tornando-se uma réplica da população geral. E por último parâmetro é uma medida numérica que pode descrever uma característica da população.

Para Milone (2004), a estatística dividi-se em três grandes áreas: a estatística descritiva, a probabilística e a inferência. A primeira - estatística descritiva, refere-se à coleta e distribuição dos dados relativos aos eventos ou fenômenos estudados. A estatística probabilística refere-se a resultados possíveis, mas incertos; e por último a inferência, que consiste nos modos de concluir ou predizer algo que seja possível com base em fatos concretos.

Sabe-se que na estatística, o princípio básico são os dados, pois deles que serão extraídas todas as informações possíveis sobre qualquer evento ou pesquisa que seja realizada. Para Milone (2004), a estatística segue o princípio de Lorde Kelvin (Milone, 2004, p. 4):

quando se pode medir aquilo sobre o qual se está falando e expressá-lo em números, sabe-se algo sobre ele; quando não se pode expressá-lo em números, o conhecimento é escasso e de natureza insatisfatória

Dessa forma, a natureza dos dados podem ser qualitativas ou quantitativas. São quantitativas quando os dados representam contagens ou medidas, e qualitativas quando esses dados representam características não-numéricas.

\section{TÉCNICAS DE ESTATÍSTICA DESCRITIVA}

A estatística descritiva, como o póprio nome sugere, constitui-se em um conjunto de técninas que tem por função analisar, descrever e interpretar os dados númericos de uma população ou amostra. Para (FONSECA; MARTINS, 1996), a estatística tem como objetivo encontrar leis de comportamento para todo o conjunto, por meio da sintetização dos dados númericos, por meio de figuras, tabelas e medidas.

Para estudar grandes conjuntos de dados, é mais conveniente organizá-los, de modo que reúnam valores parecidos, construindo uma tabela de freqüências. Para Triola (1998), a tabela de freqüência relaciona valores, juntamente com contagem do número de valores que se enquadram em cada categoria. A (tabela 1) é um exemplo de frequiência com 10 classes. Com a tabela, serão explicadas algumas definições de estatística como: limites inferiores de classes, limites superiores de classes, marcas de classe e amplitude de classe.

Tabela 1: Cargas Axiais de latas de alumínio

\begin{tabular}{cc}
\hline Carga Axial & Freqüência \\
\hline $200-209$ & 9 \\
\hline $210-219$ & 3 \\
\hline $220-229$ & 5 \\
\hline $230-239$ & 4 \\
\hline $240-249$ & 4 \\
\hline $250-259$ & 14 \\
\hline $260-269$ & 32 \\
\hline $270-279$ & 52 \\
\hline $280-289$ & 38 \\
\hline $290-299$ & 14 \\
\hline \multicolumn{2}{c}{ Fonte: TRIOLA (1998, p.20) }
\end{tabular}


Na tabela 1 a frequiência significa que na primeira classe, por exemplo, há 9 valores entre 200 e 209, assim como nos entre 210 e 219 há 3 valores. Os limites inferiores de classes são os menores números que pertencem à classe (por exemplo: na primeira classe, o limite inferior é 200). Limite superior de classe é o maior número da classe. As marcas de classe são os pontos médios das classes. E amplitude de classe é a diferença entre dois limites de classes inferiores consecutivos ou entre duas fronteiras inferiores de classes consecutivas.

Entendido isso, é preciso conhecer as medidas de tendência central, que é onde há mais informações da distribuição de freqüência. Para Triola (1998, p. 31) "uma medida de tendência central é um valor no centro ou no meio do conjunto de dados". Há diferentes definições para a tendência de medida central, inclusive a média, moda, mediana e ponto médio.

A média (aritmética) é o centro do conjunto dos dados. Para Milone (2004), "a média é o ponto de equilíbrio do conjunto". A média de um conjunto de valores, é a soma de todos e dividido pelo número de valores.

A mediana de acordo com Triola (1998, p. 32) "é o valor do meio desse conjunto, quando os valores estão dispostos em ordem crescente (ou decrescente)". Para descobrir a mediana, primeiro deve-se obter $50 \%$ dos dados.

A moda de um conjunto de dados é o valor que ocorre com maior frequiência. Ou seja, nessa medida é preciso achar a classe com maior frequiência. Quando dois valores ocorrem com a mesma freqüência, o conjunto se diz bimodal.

Outro ponto de grande importância para a estatística é a medida de variabilidade, também conhecida como medida de dispersão, que se refere a quanto os valores podem diferir entre si. Esses valores vão estar sempre em torno da média. Para isso, usa-se a de alguns conceitos como amplitude total, desvio médio, variância, o desvio padrão e o coeficiente de variação.

Entende-se por amplitude total, a diferença entre o maior e o menor dos valores da série. Segundo (FONSECA; MARTINS, 1996, p 141), "a utilização da amplitude total como medida de dispersão é muito limitada, pois sendo uma medida que depende apenas doas valores externos, é instável, não sendo afetada pelos valores internos".

O desvio médio é a medição da dispersão dos dados em relação à média, ou seja, analisar os desvios, procurando entender e a fim de descobrir suas possíveis causas. Já a variância, trata-se da média aritmética dos quadrados dos desvios, ou seja, o desvio médio elevado ao quadrado.

O desvio padrão é a mais importante medida de variação. Para Triola (1998) o desvio padrão de um conjunto de valores amostrais é uma medida da variação dos valores em relação à média. O desvio padrão tem vários usos. Segundo Milone (2004), serve para padronizar algumas medidas e distribuições, como as assimetrias e a distribuição normal. A variância é o quadrado do desvio padrão.

O coeficiente de variação é o mesmo que o desvio padrão, só que em porcentagem. De acordo com Fonseca e Martins (1996, p. 147), o coeficiente de variação "trata-se de uma 
medida relativa de dispersão útil para a comparação em termos relativos do grau de concentração em torno da média de séries distintas".

$\mathrm{Na}$ estatística, quando os dados são organizados e analisados, podem e geralmente são, colocados em figuras para melhorar a compreensão do fenômeno. O mais importante nos figuras é o comportamento, a tendência. As modalidades dos figuras são de acordo com as variáveis usadas na análise. Podem ser: de uma variável (gráfico pizza, por exemplo); várias variáveis (figura de barras); ou ainda os de marketing, que são figuras com desenhos. Esses figuras permitirão uma melhor explanação dos dados e a compreensão destes de forma a facilitar a sua análise.

\section{TÉCNICAS DE CORRELAÇÃo E REGRESSÃO}

A correlação como afima (TRIOLA, 1998), é a relação entre duas variáves com auxílio de uma figura (chamado diagrama de dispersão) e de uma medida (chamada coeficiente de regressão linear). Ou seja, tenta determinar como o relacionamento de uma variável pode influenciar diretamente em outra variável.

Segundo Triola (1998), essa correlação consiste em utilizar dados emparelhados (às vezes chamados de dados bivariados. Para isso, são determinadas duas viariáveis: a variável $X$ e a variável $Y$. Para um menlhor entendimento de como fuciona a correlação, será utilizado um exemplo hipotético: o quanto o número de funcionários $(Y)$ pode influenciar no índice de produção da empresa $(X)$. Observe a tabela 2:

Tabela 2: Influência do Funcionários na Produção de uma Empresa

\begin{tabular}{cc}
\hline FUNCIONÁRIOS & PRODUÇÃO (Unid/dia) \\
\hline 30 & 320 \\
\hline 50 & 530 \\
\hline 70 & 750 \\
\hline 85 & 850 \\
\hline \multicolumn{2}{c}{ Dados Hipotéticos. Fonte: a autora. }
\end{tabular}

Como pode-se observar na tabela 2 , o número de funcionário influencia diretamente no número de unidades produzidas na empresa. Isso quer dizer que há correlação entre a variável $X$ e a variável $Y$, ou seja, quanto maior o número de funcionários, maior será a produção. $\mathrm{O}$ inverso também é verdadeiro: quanto menor o número de funcionários, menos será a produção da empresa.

O índice de correlações e não-correlações, segundo (MILONE, 2004), se assemelham em muitos aspectos. Ainda segundo ele, ambos variam entre -1 e +1 . Esses sinais são dados pelas correlações entre as variantes, ou seja, quanto mais próximo de +1 , mais correlação haverá entre as variáveis.

Após analisar os dados, com o objetivo de analisar se há correlação, descreve-se essa relação em um figura, a fim de determinar uma reta, essa reta é chamada de reta de regressão. Segundo Triola (1998), o figura da equação de regressão é chamado de reta de regressão (ou reta de melhor ajuste, ou reta de mínimos quadrados).

De cordo com Triola (1998, p. 234), "descrevem-se as relações lineares entre duas variáveis com o auxílio da equação e do figura de uma linha reta, chamada reta de regressão". 
Um aspecto importante da amostra ou da população de valores é o quanto dispersas elas são. Ou seja, quanta variação exixte entre a população e a amostra. De acordo com (DANCEY, 2006, p.91), "uma maneira simples de se ter uma indicação da dispersão dos valores de uma amostra ou população é comparar o valor máximo com o mínimo". Esse valor máximo é conhecido como amplitude. Ainda segundo ele, a amplitude é simplesmente a diferença entre os valores máximo e mínimo. Por exemplo, na presente pesquisa é 50, isto é, 51 Empresas (valor máximo) menos 1 Empresa (valor mínimo).

\section{TÉCNICAS DE TABULAÇÃO E ANÁLISE NO SPSS}

O Statistical Package for Social Sciences (SPSS) é uma aplicação que proporciona um poderoso tratamento estatístico de dados, combinando as potencialidades gráficas com uma gestão desses dados (DANCEY, 2006).

Teve a sua primeira versão em 1968 e é um dos programas de análise estatística mais usados nas ciências sociais; é também usado por pesquisadores de mercado, pesquisas de opinião, entre outros. Em 1984 saiu a primeira versão para computadores pessoais.

O software é em inglês. A figura 1 mostra a página inicial do software.

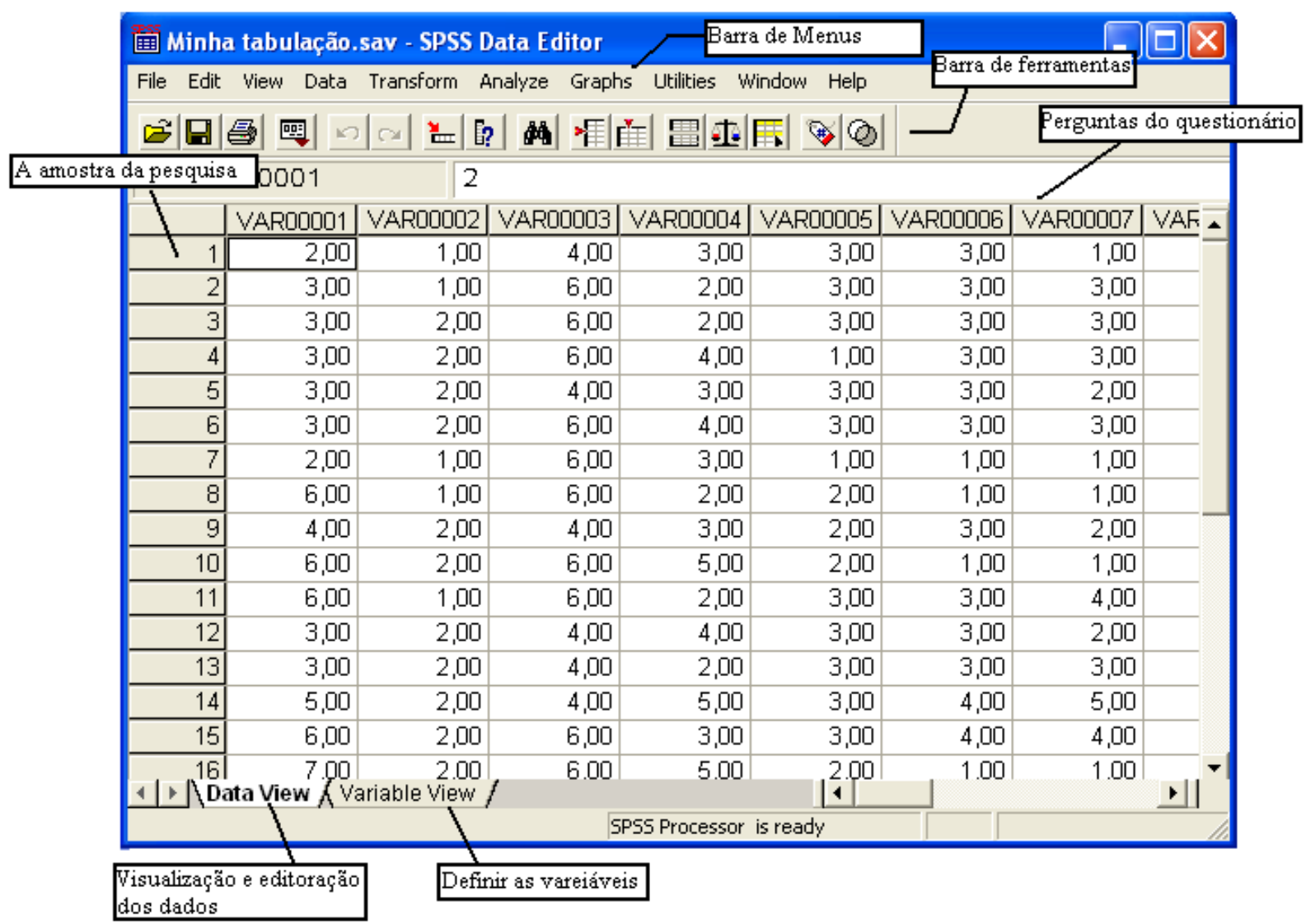

Figura 1 - Página Inicial do Software.

Fonte: Pesquisa de Opinião, 2009. Elaboração: a autora.

A figura 1 contém a pagina inicial do software. A barra de menus e a barra de ferramentas são responsáveis pelos comandos do software. Na coluna que está marcada como amostra 
da pesquisa, essa coluna irá conter a amostra que está sendo pesquisada, no caso do presente trabalho são as empresas exportadoras de Natal e alguns municípios da região metropolitana.

Na linha que está marcada como perguntas do questionário, (VAR00001, VAR00002...), ficam as variáveis da pesquisa, ou seja, cada questão que será estudada e analisada.

A Data View, serve para a visualização e editoração dos dados, que são os dados que foram coletados na pesquisa, esses dados são representados por números que correspondem a cada reposta de cada pergunta feita. A Variable View, serve para definir as variáveis, ou seja, detalhar cada questão, colocando nomes e os intervalos das respostas para possível análise na estatística descritiva.

Para inserir os dados no software, primeiro é preciso que a tabulação seja organizada no Excel, e só depois, copiada para o SPSS. A figura 2 mostra a página da Variable View.

\begin{tabular}{|c|c|c|c|c|c|c|c|c|}
\hline \multicolumn{7}{|c|}{ 箅 Minha tabulação.sav - SPSS Data Editor } & \multicolumn{2}{|c|}{$=\square \times$} \\
\hline File Edit View Data & Transform A & yze Grap & ר Utilities W & Idow Help & & & & \\
\hline \multicolumn{9}{|c|}{ 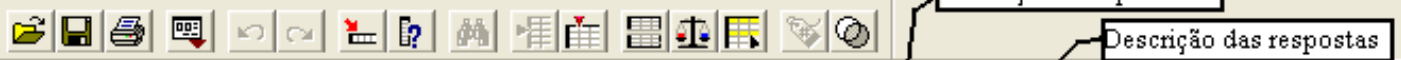 } \\
\hline Name & Type & Width & Decimals & Label & Valu & Missing & \multicolumn{2}{|c|}{$\mathrm{Cc}-1$} \\
\hline 1 VAR00001 & Numeric & 8 & 2 & Região admini & $\{1,00$, Nore & Oone & \multicolumn{2}{|c|}{8} \\
\hline 2 VAR00002 & Numeric & 8 & 2 & Sexo & $\{1,00$, Femtnim & None & \multicolumn{2}{|l|}{8} \\
\hline VAROOOOO3 & Numeric & 8 & 2 & Grau de Instru & $\{1,00$, Primeiro & None & \multicolumn{2}{|l|}{8} \\
\hline VAR00004 & Numeric & 8 & 2 & Faixa etária & $\{1,00$, até 20 a & None & \multicolumn{2}{|l|}{8} \\
\hline alue Labels & \multirow{2}{*}{\multicolumn{3}{|c|}{ Iodelo de Values }} & $?$ & $\{1,00$, Preside & None & 8 & \\
\hline & & & & a Empr. & $\{1,00$, Micro $\} \ldots$ & None & 8 & \\
\hline Value Labels - & & & & de Fu & $\{1,00$, Até 15$\}$. & None & 8 & \\
\hline \multirow{2}{*}{$\begin{array}{l}\text { Value: } \\
\text { Value Label: }\end{array}$} & & & & esa ven. & $\{1,00$, Mercado & None & 8 & \\
\hline & & & & enjuntur & $\{1,00$, Ótima $\}$. & None & 8 & \\
\hline & \multirow{5}{*}{$\begin{array}{l}1,00=\text { "Norte" } \\
2,00=\text { "Sull" } \\
3,00=\text { "Leste" } \\
4,00=\text { "Deste" } \\
5,00=\text { "Macaíba" }\end{array}$} & & & Help & $\{1,00$, Ótima $\}$. & None & 8 & \\
\hline & & & 스 & de inse & $\{1,00$, Até 2 an & None & 8 & \\
\hline Change & & & 브 & de inse & $\{1,00$, Até 2 an & None & 8 & \\
\hline Remove $\mid \begin{array}{l}4,0 \\
5,0\end{array}$ & & & $\underline{v}$ & program & $\{1,00, \operatorname{Sim}\} \ldots$ & None & 8 & \\
\hline & & & & de inser & $\{1,00$, Por inici & None & 8 & \\
\hline 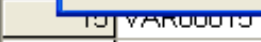 & TvणmाETाL & U & $z$ & 1 a्राणप & $\{1,00$, Preço d & None & 8 & \\
\hline 16 VAR00016 & Numeric & 8 & 2 & A situação eco & $\{1,00$, Boa ten & None & 8 & \\
\hline 17 VAR00017 & Numeric & 8 & 2 & A empresa pa & $\{1,00$, Ocorre e & None & 8 & \\
\hline 18 VAR00018 & Numeric & 8 & 2 & A participação & $\{1,00$, Pequen & None & 8 & \\
\hline 19 VAR00019 & Numeric & 8 & 2 & Dificuldade en & $\{1,00$, Por que & None & 8 & \\
\hline 20) VAR00020 & Numeric & 8 & 2 & Dificuldade en & $\{1,00$, Altas ca & None & 8 & \\
\hline 21 VAR00021 & 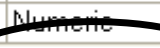 & & 2 & Como a empre & $\{1,00, A$ empre & None & 8 & $\nabla$ \\
\hline 4 Data View & iable Vie & & & -1 & & & $\perp$ & 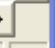 \\
\hline & & & & ready & & & & \\
\hline
\end{tabular}

Figura 2 - Página da Variable View.

Fonte: Pesquisa de Opinião, 2009. Elaboração: a autora.

Como se pode ver na figura 2 , há duas colunas marcadas que são de extrema importância na tabulação dos dados. A primeira chama-se label,nela são escritas todas as questões de acordo com que estão organizadas no questionário, e que já foram escritas na primeira tabela (name - onde contém todas as variáveis), para que uma vez colocadas no figura possam ser analisadas quantitativamente, e identificadas por nomes.

A segunda coluna que é importante citar, é a cujo nome chama-se values, esta coluna contém todas as respostas de cada questão do questionário. Nela, nós usamos número a fim 
de identificar cada reposta, como mostra a caixa de texto da figura (Value labels). Para poder modificá-la, clicamos nos três pontos (...) que aparecem na célula, e abre a caixa de texto que aparece na figura 2.

Essa caixa de texto permitirá dar nomes as respostas, ou seja, você adiciona um número para representar a resposta (por exemplo, na questão que diz respeito a região entrevistada: $1=$ Norte, 2 = Sul, $3=$ Leste, e assim por diante, procurando sempre seguir a ordem de respostas do questionário, depois clica em $a d d$, e depois em $o k$.

Concluída essa parte, é preciso construir as tabelas para melhor analisar as respostas, e conseqüentemente chegar aos objetivos esperados da pesquisa. Com a figura 3 será possível analisar melhor.

\begin{tabular}{|c|c|c|c|c|c|c|c|c|}
\hline 䧃 Minha & tabulação.: & sav - SPSS & Data Editor & & & & $\square$ & \\
\hline File Edit & View Data & Transform & Analyze Graphs Utilities & Window Help & & & & \\
\hline & 冝| 回 & & Reports & - -1 solal & & & & \\
\hline 汪四 & 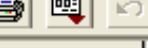 & $|\mathrm{C}| \mathrm{I}$ & Descriptive Statistics & Frequencies... & & & & \\
\hline & Name & Type & Tables & Descriptives... & Values & Missing & $\mathrm{Cc}-$ & \\
\hline 1 & VAR00001 & Numeric & Compare Means & Explore... &, 00, Norte \}... & None & $\overline{8}$ & \\
\hline 2 & VAR00002 & Numeric & General Linear Model & Crosstabs... & 00, Feminin & None & 8 & \\
\hline 3 & VAR00003 & Numeric & Mixed Models & Ratio... &, 00 , Primeiro & None & 8 & \\
\hline 4 & VAR00004 & Numeric & Correlate & Faixa etária & $\{1,00$, até 20 a & None & 8 & \\
\hline 5 & VAR00005 & Numeric & $\begin{array}{l}\text { Regression } \\
\text { Loglinear }\end{array}$ & Cargo que exe & $\{1,00$, Preside & None & 8 & \\
\hline 6 & VAR00006 & Numeric & $\begin{array}{l}\text { Loginiear } \\
\text { Classify }\end{array}$ & Porte da Empr & $\{1,00$, Micro $\} \ldots$ & None & 8 & \\
\hline 7 & VAR00007 & Numeric & Data Reduction & Número de Fu & $\{1,00$, Até 15$\}$. & None & 8 & \\
\hline 8 & VAR00008 & Numeric & Scale & A empresa ven & $\{1,00$, Mercado & None & 8 & \\
\hline 9 & VAR00009 & Numeric & Nonparametric Tests & Atual conjuntur & $\{1,00$, Ótima $\}$. & None & 8 & \\
\hline 10 & VAR00010 & Numeric & Time Series & A.tual conjuntur & $\{1,00$, Ótima $\}$. & None & 8 & \\
\hline 11 & VAR00011 & Numeric & Survival & Tempo de inse & $\{1,00$, Até 2 an & None & 8 & \\
\hline 12 & VAR00012 & Numeric & Multiple Response & Tempo de inse & $\{1,00$, Até 2 an & None & 8 & \\
\hline 13 & VAR00013 & Numeric & $\begin{array}{l}\text { Missing Value Analysis... } \\
\text { Complex Samples }\end{array}$ & Utiliza program & $\{1,00, \operatorname{Sim}\} \ldots$ & None & 8 & \\
\hline 14 & VAR00014 & Numeric & $\begin{array}{l}\text { Complex Samples } \\
{ }^{2}\end{array}$ & Forma de inser & $\{1,00$, Por inici & None & 8 & \\
\hline 15 & VAR00015 & Numeric & 8 & Fator que interf & $\{1,00$, Preço d & None & 8 & \\
\hline 16 & VAR00016 & Numeric & 8 & A situaçẫo eco & $\{1,00$, Boa ten & None & 8 & \\
\hline 17 & VAR00017 & Numeric & 8 & A empresa pa & $\{1,00$, Ocorre e & None & 8 & \\
\hline 18 & VAR00018 & Numeric & 8 & A participação & $\{1,00$, Pequen & None & 8 & \\
\hline 19 & VAR00019 & Numeric & 8 & Dificuldade en & $\{1,00$, Por que & None & 8 & \\
\hline 20 & VAR00020 & Numeric & 2 & Dificuldade en & $\{1,00$, Altas ca & None & 8 & \\
\hline 21 & VAR00021 & Numeric & 8 & Como a empre & $\{1,00$, A empre & None & 8 & $\nabla$ \\
\hline \begin{tabular}{l|l|l|l|}
1 & 1
\end{tabular} & ata view $\mathrm{AVa}$ & ariable View & & $|4|$ & & & 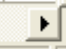 & \\
\hline Frequencie: & & & SPSS Process & or is ready & & & & \\
\hline
\end{tabular}

Figura 3 - Elaboração de Tabelas.

Fonte: Pesquisa de Opinião, 2009. Elaboração: a autora.

Como mostra a figura 3, para a construção de tabelas, clica-se em Analyze, em seguida clica em Descriptive Statistics, e depois em Frequencies. O software permite a construção de vários tipos de tabelas, porém as usadas no presente trabalho, visa estudar as frequiências ocorridas, ou seja, com que freqüência foram dadas determinadas respostas. A figura 4 apresenta melhor. 


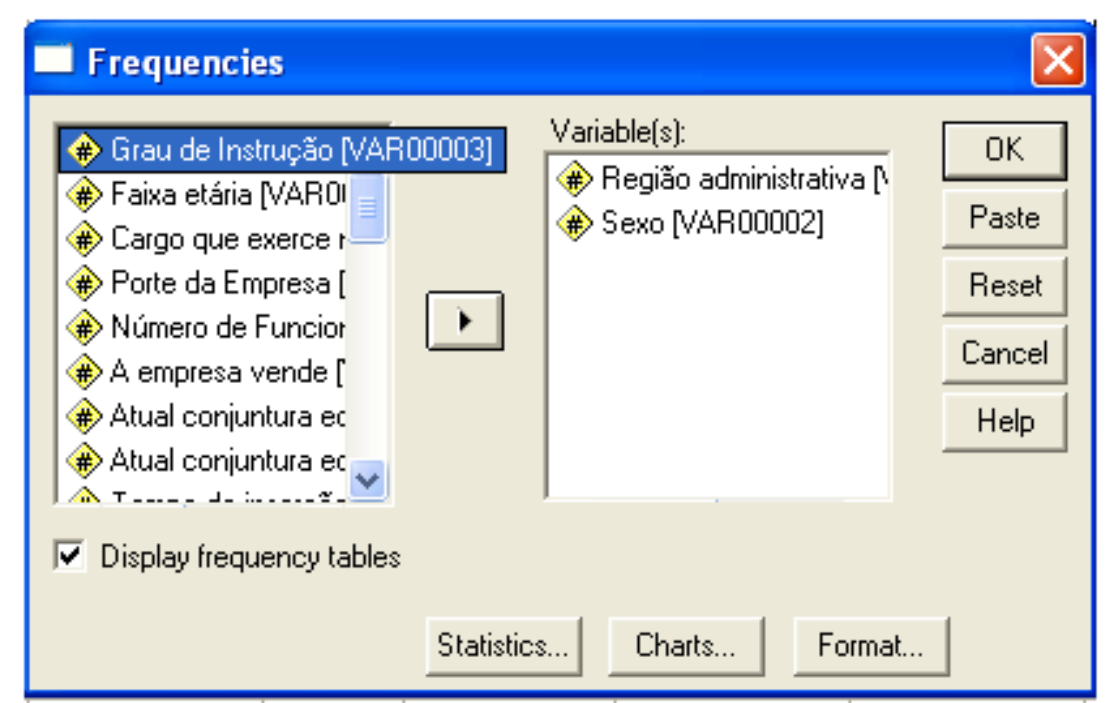

Figura 4 - Continuação Elaboração de Tabela.

Fonte: Pesquisa de Opinião, 2009. Elaboração: a autora.

Seguido os passos da figura 3, aparecerá uma caixa de texto que está representada pela figura 4. Para criar a tabela de cada variável, é preciso selecionar a variável e passá-la para o quadro ao lado, clicando na seta. Depois de definidas as variáveis é só clicar em $O k$, e as tabelas são mostradas em outra janela, onde pode-se selecionar e importar para o Microsoft Word, e editar da maneira desejada.

Para a construção de figuras, a figura 5, nos ajuda a entender como montar os figuras usando o software.

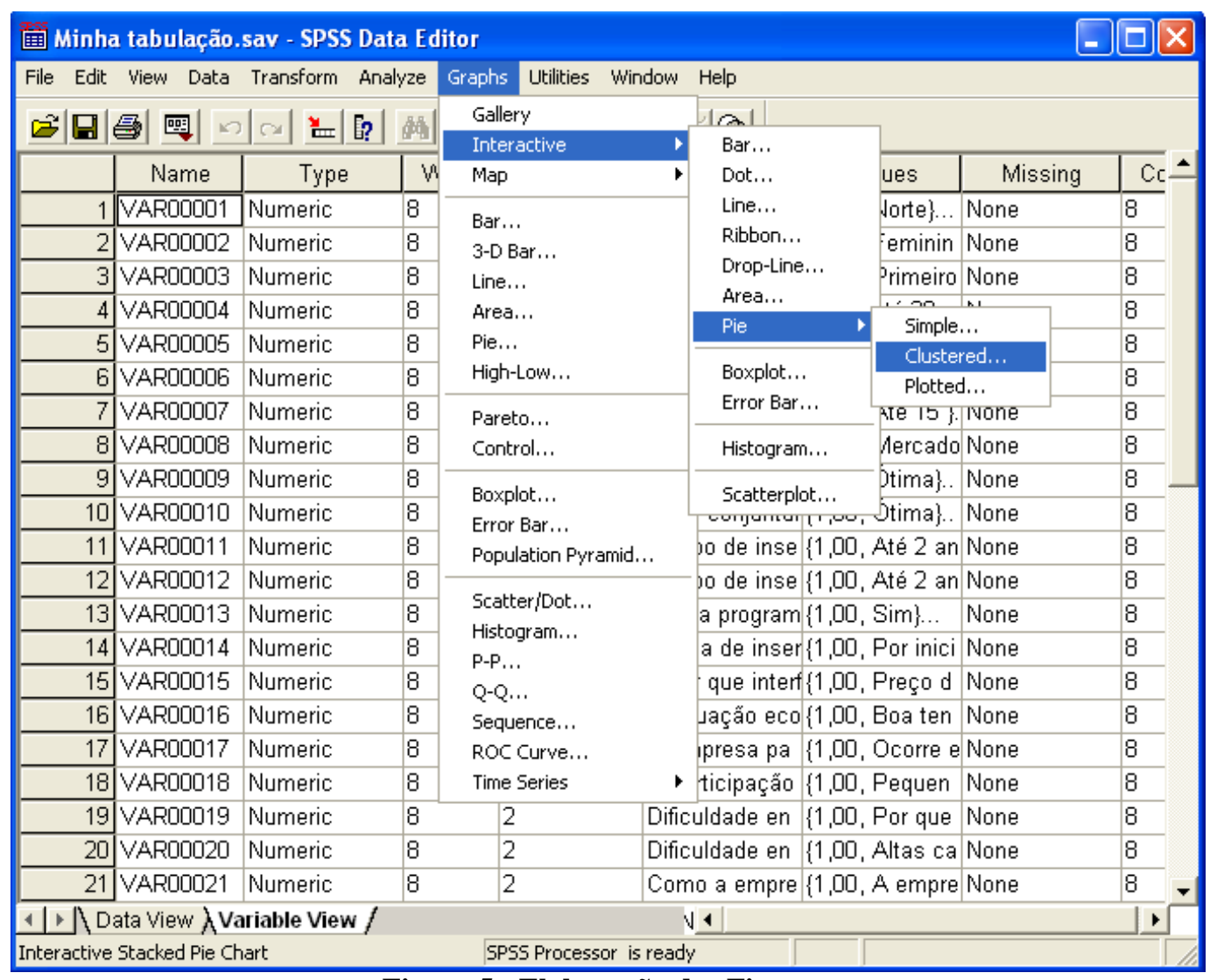

Figura 5 - Elaboração dos Figuras. 
Fonte: Pesquisa de Opinião, 2009. Elaboração: a autora.

Para a construção dos figuras, o passo a ser seguido é o da figura 5. Primeiro clica em Graphs, em seguida em interactive, pie, clustered. Essa sequência permite a construção de figuras do modelo conhecido como figura pizza. É um dos modelos mais usados na estatística para analisar os dados, e este tipo de figura será utilizado no trabalho.

Após feito isso, aparecerá uma janela para a construção dos figuras, a figura 6, servirá como base para o entendimento da elaboração dos figuras.

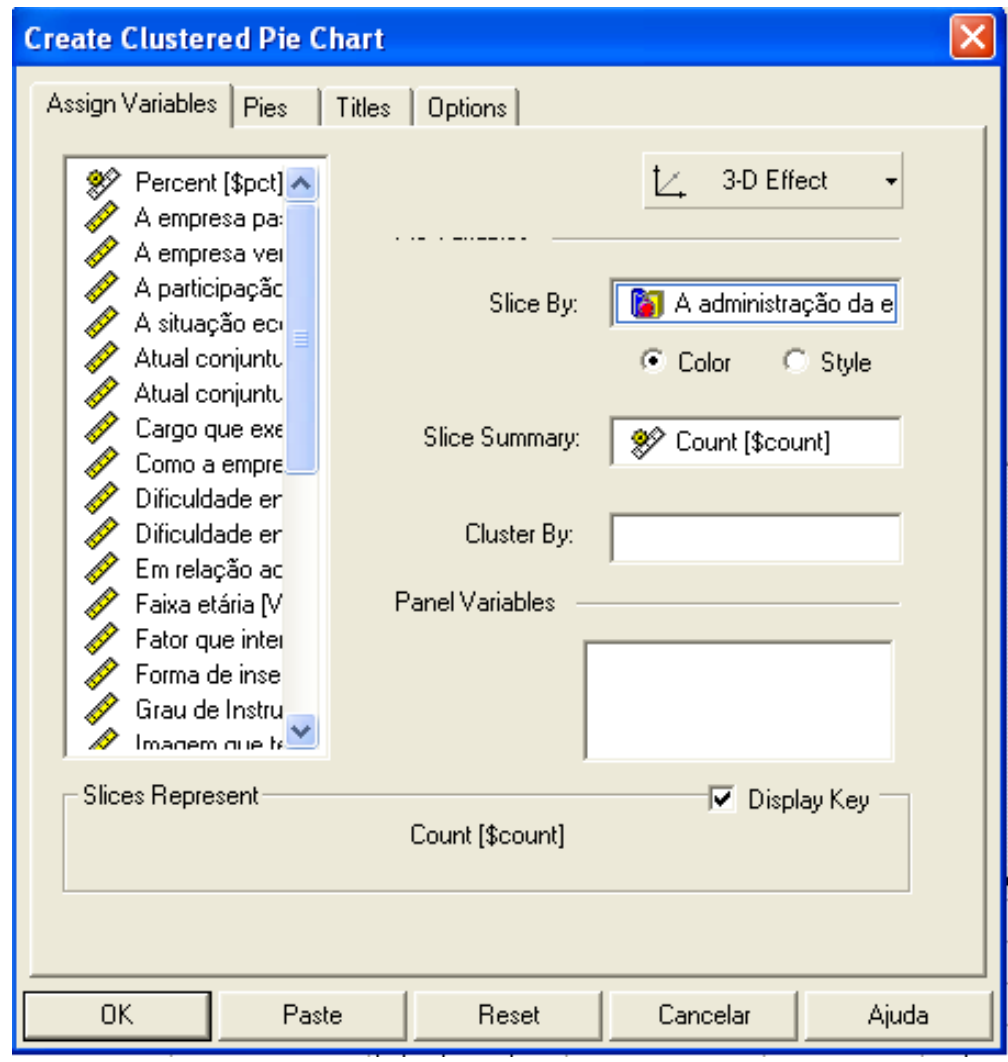

Figura 6: Continuação da Elaboração dos Figuras.

Fonte: Pesquisa de Opinião, 2009. Elaboração: a autora.

Na figura 6, para montar o figura é preciso selecionar a variável desejada, depois adicionála em Slice By, e clicar em ok. Aparecerá uma outra janela, com o figura, que poderá ser editado, podendo modificar cores, e posições. Para usá-lo, é só importar para o Microsoft Word ou outro programa desejado.

Com isso, os figuras poderão ser analisados, e melhor explorados, para que se possa extrair os objetivos da pesquisa, e para melhor demonstrar os vários escopos aos leitores do trabalho que está sendo objetivado.

Portanto, como foi possível observar, o software foi de extrema importância na tabulação dos dados, uma vez que facilita a análise e apresenta através de figuras e tabelas o cenário que a pesquisa objetiva, bem como as ocorrências e as possíveis relações de uma variante com outra, por exemplo, para provar que a existência de um fator pode determinar um outro. 


\section{A IMPORTÂNCIA DAS EMPRESAS EXPORTADORAS}

O comércio internacional é de suma importância para o desenvolvimento de um país, e o seu reconhecimento no mercado externo. Assim, grandes exportadores trazem resultados significativos também para a economia de um estado, contribuindo para o Produto Interno Bruto da região.

Há alguns críticos que defendem teses como a de que não se pode exportar sem antes alimentar a 'fome do povo'. É o que afirma o jornalista e comentarista Sandenberg, em entrevista dada ao site Global 21. Para ele, o governo deveria criar uma ambiente favorável aos negócios, proporcionando uma infra-estrutura que permita o aumento das vendas externas e das importações.

O site Global 21, afirmou que nos últimos dez anos as exportações brasileiras cresceram em uma média anual de $11 \%$, enquanto o PIB teve um crescimento médio de $1,8 \%$ para o mesmo período. Então o site questionou a Sandenberg, "isso prova que as exportações não promove o crescimento?" Sandenberg em resposta, questiona: "Mas você também pode perguntar: se não tivesse havido as exportações, teria crescido quanto? Nada, não é mesmo? É fácil você medir o impacto das exportações no PIB: basta olhar os relatórios do IBGE". Sandeberg ainda argumenta que para provar isto basta olhar o exemplo de países que mais cresceram nas últimas décadas: Japão, Coréia do Sul e agora China. Onde todos têm um ponto em comum: "exportar, exportar, exportar".

Maia (2007), critica a política exportadora do Brasil, dizendo que no passado ela se apoio, em: moeda desvalorizada; manipulação de tarifas; mão-de-obra barata; e subsídios, que segundo ele, esse modelo prejudicou as exportações brasileiras por que o Brasil foi perdendo posição no mercado internacional.

O quadro 1 contém as exportações mundiais de mercadorias e exportações brasileiras de mercadorias para uma melhor análise da conjuntura econômica mundial a partir dos anos 80 .

\begin{tabular}{|l|l|l|l|}
\hline Anos & Exportações Mundiais & Exportações Brasileiras & \% Brasil/Mundo \\
\hline 1980 & 1.940 & 20,1 & 1,04 \\
\hline 1991 & 3.498 & 31,6 & 0,90 \\
\hline 2000 & 6.295 & 55,1 & 0,88 \\
\hline 2002 & 6.306 & 60,4 & 0,96 \\
\hline 2004 & 8.445 & 96,5 & 1,05 \\
\hline 2005 & 10.186 & 118,3 & 1,16 \\
\hline 2006 & 11.721 & 137,5 & 1,17 \\
\hline
\end{tabular}

Quadro 1 - Exportações Mundiais de Mercadorias e Exportações Brasileiras (US\$ Bilhões) Fonte: MDIC e OMC

Percebe-se que, segundo o quadro 1, a participação das exportações brasileiras no comércio mundial, até o ano de 2002, era inexpressiva, abaixo de $1 \%$. A partir de 2002, o Brasil começou a aumentar seu volume de exportação, embora ainda com uma participação muito pequena no mercado mundial. 
De acordo com (Maia, 2007), as exportações brasileiras sofreram com a crise argentina em 1997, quando o Brasil exportou para o Mercosul, US\$ 9.046 milhões; em 2002, apenas US\$ 3.310 milhões (MDIC). Ainda segundo ele, isso fez o Brasil procurar por novos mercados, principalmente da China, índia, África do Sul, Cingapura e Emirados Árabes. Diante desses números, as autoridades brasileiras modificaram a política de financiamentos às exportações para incentivar pequenas e médias empresas para exportar.

Segundo (MAIA, 2007), para aumentar as exportações o governo brasileiro tem lutado na Organização Mundial do Comércio (OMC), contra as restrições impostas pelos Estados Unidos da América ao aço brasileiro e ao suco de laranja. O Brasil tem questionado também os subsídios do governo americano à produção e à exportação do algodão, bem como o regime europeu de subsídios de açúcar.

Como a economia é instável e costuma passar por momentos de recessão e crescimento, a economia de um país sofre mutações ao longo dos tempos. Foi o que acontece com a crise de 2002, que englobou a crise cambial brasileira, onde resultou na depreciação do real em 53\% em relação ao dólar (CRISE...2003). A depreciação da moeda brasileira teve início em abril e atingiu o seu ponto máximo em setembro de 2002; véspera da eleição presidencial em que havia uma elevada probabilidade de vitória (concretizada) de um partido de esquerda. Essas crises afetam diretamente e indiretamente o mercado internacional e as exportações das empresas.

Com a crise de 2008, quando o mercado imobiliário dos Estados Unidos despencou, não foi diferente. Dezenas de empresas foram à falência, e grandes exportadores precisaram retrair o seu crédito para superar a crise. Sendo assim, o mercado internacional sofreu drasticamente, visto que os governos começaram a valorizar o produto nacional, a fim de manter as empresas locais funcionando (CRISE, 2009).

Segundo Maia (2007), há dois grandes problemas que prejudicam as exportações brasileiras. São eles:

- $\quad$ Cerca de $80 \%$ das rodovias brasileiras são classificadas como deficientes, ruins ou péssimas. Isso encarece o custo dos transportes, o que prejudica as exportações;

- A participação das ferrovias no transporte brasileiro é de $24 \%$. A dos caminhões, 63\%. Isso também encarece o custo dos transportes. Portanto, há necessidade de investimentos em nossas estradas de ferro para que haja expansão e modernização das vias já existentes, o que tornaria nossos produtos mais competitivos.

Outro fator importante nas exportações brasileiras são os portos, uma vez que a costa marítima brasileira oferece condições para a construção de superportos. Isso já não acontece nos Estados Unidos e a China, porque devido à natureza de suas plataformas continentais, tornam-se difíceis essas construções (Elieser Baptista da Silva e Roberto Y. Hukay em O Estado de São Paulo, de 25/11/1996).

\section{PROBLEMAS QUE PREJUDICAM AS EXPORTAÇÕES BRASILEIRAS}

Apesar de a costa brasileira ter ótimas condições, a situação dos portos brasileiros é bem delicada. Embora, com a Lei de Modernização dos Portos, $\mathrm{n}^{\circ}$ 8.630, de 25 de fevereiro de 1993, houve acentuada melhoria. 
Segundo Maia (2007), o Brasil tem uma quantidade muito grande de portos. Os mais importantes estão localizados nas cidades de Santos e Rio de Janeiro. Mas apesar da grande quantidade são considerados ineficientes. Como havia projeto de privatização, o governo não investia em equipamentos modernos, o que os tornava ainda mais obsoletos. Em 1995, a Confederação Nacional da Indústria (CNI) (apud Maia 2007, pg 44), realizou uma pesquisa sobre o sistema portuário brasileiro. As respostas foram:

- $\quad 75,3 \%$ dos entrevistados apontaram o monopólio dos sindicatos na condução dos contratos de trabalho nos portos;

- $\quad 68,3 \%$ apontaram ineficiência das Companhias de Docas na prestação dos serviços;

- $\quad 66,6 \%$ alegaram inadequação e complexidade do sistema aduaneiro;

- 60,1 salientaram custos elevados das operações nos portos devido ao obsoletismo das instalações portuárias;

- $\quad$ 51,5 citaram congestionamentos freqüentes e falta de instalações adequadas para a estocagem de mercadorias.

Em resumo, os grandes problemas portuários no Brasil são: ineficiência, insegurança e custos elevados.

\section{Ineficiência}

De acordo com Maia (2007), segundo levantamento feito pela Aliança Navegação, seis entre os dez piores portos do mundo eram brasileiros. Por esse motivo, contribuíram para elevar o chamado custo Brasil, dificultando as exportações. Esse trabalho levou em consideração: produtividade, custo de carregamento e descarregamento, despesas portuárias com atracação, utilização de rebocadores e outros e custo de estadia do navio no porto.

Segundo Vazquez (2001), a Intel, empresa americana fabricante de chips, desistiu de implantar uma filial no Brasil e transferiu o projeto para Costa Rica, isso porque as importações da empresa demorariam dois dias para sair do porto brasileiro. Na costa Rica, o desembaraço das importações levou apenas três horas.

Vazquez (2001), mostrou que o porto de Cingapura movimenta em um ano 17 milhões de contêineres. O de Santos, maior do Brasil, movimenta também em um ano 0,988 milhão.

Segundo cálculos feitos pela Associação Brasileira de Comércio Exterior, a ineficiência, dos portos brasileiros reduz as exportações em US\$ 5 bilhões. Lembrando que perda de exportações significa também perda de emprego.

\section{Insegurança}

De acordo com a Maia (2007), a costa brasileira era a terceira pior área do mundo. No primeiro semestre de 1997, ocorreram 136 assaltos, sendo:

- $\quad 73$ no Mar da China;

- 19 no Oeste da África

- 16 no Brasil;

- 28 em diversos países. 
Em abril de 1997, houve um episódio inédito; de acordo com a nova Lei dos Portos, a Cosipa contratou mão de obra própria, sem a interferência do sindicato. Em razão disto, houve greve e invasão do porto e de dois navios, o que provocou grande prejuízo para as empresas.

\section{Custo Elevados}

O presidente do Centro Nacional de Navegação Transatlântica (Centronave), Robert Higgin, ressalta as melhorias nos dois terminais do Rio de Janeiro e nos portos de Santos, Cubatão, Rio Grande do Sul e Salvador. Por exemplo, no Porto de Santos, era preciso esperar dois ou três dias para atracar. $\mathrm{Na}$ atualidade, quando há espera, essa leva algumas horas.

Porém, os custos não abaixaram muito; na média, continuam altos. Há denúncias de irregularidades nos contratos de arrendamento e as Companhias Docas, ainda estatais, são deficitárias. As tarifas baixaram em alguns portos, mas os custos com mão-de-obra ainda são considerados altos pelas empresas operadoras.

Segundo levantamento feito pela Associação Brasileira dos Terminais Portuários (apud Maia, 2007), os preços dos serviços nos portos caíram cerca de $60 \%$ nos últimos seis anos. Porém, essa redução não foi suficiente para tirar o Brasil da lista dos países que possuem os portos mais caros do mundo.

\section{LEVANTAMENTO HISTÓRICO DA BALANÇA COMERCIAL BRASILEIRA}

Para entender um pouco o que estruturou a economia do país, e entender a cultura exportadora nacional, é preciso voltar na história e observar a evolução das relações internacionais desde os tempos de colonização.

As relações internacionais do Brasil iniciaram-se com a economia do Pau-Brasil no período logo após o descobrimento e mais tarde, com a divisão do Brasil em Capitanias Hereditárias, que então passou a ser o açúcar a principal atividade, e que perdurou por quase todo o período de colônia, vindo a ser substituído como principal atividade pelo ouro da região de Minas Gerais em meados do Sec. XVII. Em seguida, um novo ciclo econômico surgiu, agora com o café. Esse momento foi fundamental para o desenvolvimento do Estado de São Paulo, que acabou por tornar-se o mais rico do país.

Para Prado Júnior (1998), o que motivou o processo de transformação da economia na época de colonização foi o aparecimento do capitalismo industrial em substituição ao antigo e decadente capitalismo comercial. De acordo com ele, até o século XVII o capital que domina de uma forma quase pura é o comercial, onde a indústria ainda não entrara na fase capitalista e se acha inteiramente nas mãos do artesanato.

Segundo Júnior (1998, p. 124),

a indústria capitalista tomou tamanho vulto que ofusca o capitalismo comercial e assume cada vez mais o domínio da economia européia.Resultará daí o declínio 
o antigo sistema colonial representado pelo pacto que é uma expressão perfeita do capitalismo comercial.

Ou seja, começa uma libertação econômica e seus efeitos sobre a liberdade comercial e demais medidas que irão refletir principalmente no comércio exterior da metrópole. Segundo Prado Júnior (1998), para uma breve noção da economia daquele período, segue a quadro 2 com possíveis valores do comércio exterior do Brasil.

\begin{tabular}{|l|l|l|}
\hline Ano & Exportação & Importação \\
\hline 1812 & 1.233 .000 & 770.000 \\
\hline 1816 & 2.330 .000 & 2.500 .000 \\
\hline 1822 & 4.030 .000 & 4.590 .000 \\
\hline
\end{tabular}

Quadro 2 - Exportações do Brasil no Início do Século XIX (Em libras esterlinas-ouro) Fonte: Prado Júnior, 1998

Esse progresso econômico se deu por fato após a grande transformação operada pela revogação da política de restrições que até 1808 pesara sobre a colônia. A partir daí, o Brasil começa a sentir o desdobramento das atividades econômicas e uma maior abertura para as relações com as outras colônias.

A partir daí as relações exteriores do Brasil se tornam mais fortificadas. Para uma melhor visualização, o quadro 3, contém os dados das exportações e importações brasileiras a partir de 1821 até o ano de 1940.

\begin{tabular}{|l|l|l|l|l|}
\hline & Exportação & Importação & Exportação & Importação \\
\hline Decênios & \multicolumn{1}{l|}{ Contos de Réis } & \multicolumn{1}{l|}{$\mathbf{1} 1.000$ Ouro } & \\
\hline $1821-1830$ & 243.263 & 265.164 & 39.097 & 42.504 \\
\hline $1831-1840$ & 348.258 & 385.742 & 45.205 & 54.291 \\
\hline $1841-1850$ & 487.540 & 540.944 & 54.680 & 60.999 \\
\hline $1851-1860$ & 900.534 & 1.016 .686 & 102.007 & 115.280 \\
\hline $1861-1870$ & 1.537 .175 & 1.347 .514 & 149.433 & 131.866 \\
\hline $1871-1880$ & 1.963 .718 & 1.621 .151 & 199.685 & 164.929 \\
\hline $1881-1890$ & 2.411 .006 & 2.102 .297 & 220.725 & 192.361 \\
\hline $1891-1900$ & 7.349 .258 & 6.397 .324 & 291.017 & 252.817 \\
\hline $1901-1910$ & 8.123 .578 & 5.391 .775 & 476.222 & 318.843 \\
\hline $1911-1920$ & 12.300 .768 & 9.960 .223 & 688.038 & 546.906 \\
\hline $1921-1930$ & 32.797 .144 & 27.321 .166 & 805.848 & 574.479 \\
\hline $1931-1940$ & 41.978 .656 & 36.650 .153 & 377.024 & 300.349 \\
\hline
\end{tabular}

Quadro 3 - Exportações Brasileiras na Metade do Século XIX Início do Século XX Fonte: Prado Júnior, 1998

Percebe-se que desde a liberação econômica que ocorreu em 1808, quando o Brasil começou significativamente a fortificar suas relações econômicas. Do ano de 1808 até o ano de 1850, o Brasil passa pela era do liberalismo econômico, onde a crise do Regime Servil e a Abolição do Tráfico foram fundamentais para fortalecer a economia do país. 
Em julho de 1944, com a convenção de Bretton Woods, que participaram 44 países, inclusive o Brasil, e instituíram o Fundo Monetário Internacional, os países foram obrigados a fixar a paridade de suas moedas. O Brasil, assim sendo, fixou a sua moeda: o cruzeiro (Cr\$), que valia 18,36 Cr\$ por dólar norte-americano.

Então a partir daí o Brasil começou a cotar suas exportações e importações com a nova moeda e com o dólar norte-americano (US\$). O quadro 4, contém as exportações e importações do país, em qüinqüênios a partir de 1941 até 1965.

\begin{tabular}{|c|c|c|c|c|}
\hline & Exportação & Importação & Exportação & Importação \\
\hline Qüinqüiênios & \multicolumn{2}{|l|}{ Cr\$ 1.000} & \multicolumn{2}{|c|}{ US\$ 1.000.000 } \\
\hline $1941-1945$ & 45.888 & 32.983 & 2.334 & 1.625 \\
\hline $1946-1950$ & 106.172 & 97.764 & 5.680 & 5.183 \\
\hline $1951-1955$ & 188.115 & 211.993 & 7.712 & 8.232 \\
\hline $1956-1960$ & 440.457 & 623.875 & 6.667 & 6.911 \\
\hline $1961-1965$ & 4.494 .123 & 4.765 .792 & 7.048 & 6.781 \\
\hline
\end{tabular}

Quadro 4 - Primeiras Exportações do Brasil com a Cotação em Dólar Americano Fonte: Prado Júnior, 1998.

O quadro 4 nos mostra o grande salto que as exportações e importações obtiveram ao longo dos anos, principalmente entre os anos de 1961 a 1965. Isso porque nesse período, segundo Prado Júnior (1998, p. 316), "são anos que apresentaram um saldo positivo global de 645 milhões de dólares que encheram de otimismo e doces ilusões os defensores do capital estrangeiro".

Esse aumento se deve ao fato também ao grande impulso industrial quando o Brasil foi um agente fundamental do pós-guerra, quando o volume físico da produção mais que triplicou entre 1947 e 1961.

Para uma melhor visualização das exportações e importações brasileiras, e para melhor análise do desenvolvimento do comércio internacional no Brasil nas últimas décadas, segue um quadro contendo a evolução da balança comercial brasileira nos últimos vinte anos.

\begin{tabular}{|l|l|l|l|l|}
\hline Período & Exportação & Importação & Saldo & Saldo (\%) \\
\hline $1990 / 1991$ & 33.204 .486 .436 & 20.671 .963 .540 & 12.532 .522 .896 & - \\
\hline $1991 / 1992$ & 31.310 .548 .448 & 21.225 .858 .036 & 10.084 .690 .412 & $-19,53$ \\
\hline $1992 / 1993$ & 37.506 .822 .152 & 21.774 .673 .889 & 15.732 .148 .263 & 56,00 \\
\hline $1993 / 1994$ & 38.826 .169 .669 & 26.100 .348 .970 & 12.725 .820 .699 & $-19,11$ \\
\hline $1994 / 1995$ & 44.158 .940 .139 & 40.760 .241 .993 & 3.398 .698 .146 & $-73,29$ \\
\hline $1995 / 1996$ & 47.938 .891 .514 & 48.915 .451 .491 & -976.559 .977 & - \\
\hline $1996 / 1997$ & 48.467 .759 .416 & 55.544 .508 .528 & -7.076 .749 .112 & - \\
\hline $1997 / 1998$ & 54.187 .936 .976 & 61.104 .347 .370 & -6.916 .410 .394 & - \\
\hline $1998 / 1999$ & 48.408 .694 .550 & 53.949 .188 .779 & -5.540 .494 .229 & - \\
\hline $1999 / 2000$ & 50.496 .360 .022 & 50.800 .107 .982 & -303.747 .960 & - \\
\hline $2000 / 2001$ & 57.419 .928 .641 & 58.871 .674 .906 & -1.451 .746 .265 & - \\
\hline $2001 / 2002$ & 56.302 .707 .013 & 51.519 .796 .757 & 4.782 .910 .256 & - \\
\hline $2002 / 2003$ & 64.672 .385 .346 & 47.472 .732 .661 & 17.199 .652 .685 & 259,61 \\
\hline
\end{tabular}




\begin{tabular}{|l|l|l|l|l|}
\hline $2003 / 2004$ & 78.509 .730 .369 & 51.049 .904 .522 & 27.459 .825 .847 & 59,65 \\
\hline $2004 / 2005$ & 104.304 .449 .983 & 66.360 .889 .746 & 37.943 .560 .237 & 38,18 \\
\hline $2005 / 2006$ & 124.097 .884 .717 & 78.987 .788 .396 & 45.110 .096 .321 & 18,89 \\
\hline $2006 / 2007$ & 144.967 .200 .486 & 98.019 .988 .787 & 46.947 .211 .699 & 4,07 \\
\hline $2007 / 2008$ & 166.948 .580 .640 & 135.326 .851 .341 & 31.621 .729 .299 & $-32,64$ \\
\hline $2008 / 2009$ & 188.693 .602 .290 & 161.636 .109 .172 & 27.057 .493 .118 & $-14,43$ \\
\hline
\end{tabular}

Quadro 5 - Exportações Brasileiras nas Últimas Décadas (US\$)

Fonte: MDIC

De acordo com o quadro 5, observa-se que o comércio internacional brasileiro variou bastante nos últimos dezenove anos. Nesse período muitas empresas brasileiras começaram a exportar e muitas não conseguiram manter-se no mercado, o que se deve ao fato das dificuldades burocráticas de se manter uma empresa no Brasil, com altas cargas tributárias e o despreparo dos empresários frente ao mercado concorrido.

Observa-se que entre um período e outro a discrepância entre os saldos (\%) é muito grande, o que mostra que o mercado brasileiro é incerto. No período de 1991 a 1992, o saldo da balança comercial é de $-19,53 \%$, porém no ano seguinte o Brasil consegue se recuperar a tem um saldo positivo de $56 \%$, mas no ano seguinte o saldo volta a decair e chega a $-19,11$, atingindo quase o mesmo valor do período de 91/92.

Porém o pior desempenho brasileiro nos últimos dezenove anos foi no período de 1994/1995, quando o Brasil teve um saldo negativo de 73,29\%. Isso se deve ao fato de que em 1994, o país estava adotando um novo sistema fiscal e tributário, com o programa de estabilização econômica, que ficou conhecido como Plano Real.

Para melhor entender essa queda brusca no comércio internacional brasileiro, é preciso entender o que estava ocorrendo com a economia da época. Para isso é preciso entender o Plano Real e a sua influência na economia naquele momento.

O Plano Real, segundo Furtado (2000), compreendeu três fases distintas:

- $\quad 1^{\circ}$ Fase: iniciada em março de 1994, teve por finalidade estabelecer o equilíbrio orçamentário, mediante o aumento de impostos e cortes nos gastos públicos.

- $\quad 2^{\circ}$ Fase: foi criada a Unidade de Referência de Valor (URV), que substituía a Ufir e serviu de padrão de valor monetário. A partir de março, salário e preços sofriam correções diárias em cruzeiros reais, que com sua correção, preservou o poder de compra dos salários e o realinhamento dos preços.

- $\quad 3^{\circ}$ Fase: em $1^{\circ}$ de julho de 1994 , o governo procedeu à reforma monetária adotando o real como moeda corrente, e mantendo a paridade entre a nova moeda e o dólar (US\$ $1,00=\mathrm{R} \$ 0,93$ ).

De acordo com Furtado (2000), com o crescimento da demanda, decorrente do aumento no poder aquisitivo das classes mais baixa, houve um aumento de importações de bens de consumo. Esse fato pode ter contribuído para que a variação nas importações fosse altíssima em relação ao período anterior.

A estabilidade da moeda nacional e as taxas internas de juros, superiores às praticadas no mercado externo, deram condições para a entrada de capitais estrangeiros no país, o que também contribuiu com o volume das importações. 
Depois de passar por momentos difíceis na década passada, o Brasil mostrou seu melhor desempenho no período que vai de 2002 a 2003, quando atingiu um saldo positivo de $259,61 \%$ em relação ao período anterior.

Segundo dados divulgados pelo MDIC, o número de empresas brasileiras que exportam seus produtos no mercado externo aumentou em 2003 em relação a 2002. Em 2003, 17.743 empresas exportaram, contra 17.407 no ano anterior. O valor vendido também aumentou, passando de US\$ 60,361 bilhões para US\$ 73,084 bilhões.

Esta expansão reflete o trabalho do MDIC de atrair para a atividade exportadora novas empresas por meio de diversos programas do governo, como o Aprendendo a Exportar e os Encontros de Comércio Exterior, ambos voltados para empresas sem experiência na área.

Em 2003, 117 empresas venderam acima de US\$ 100 milhões, 13 a mais do que em 2002. Estas firmas exportaram US\$ 42,69 bilhões, representando $58 \%$ do total vendido pelo Brasil.

A maior concentração de empresas está na faixa entre US\$100 mil e US\$ 400 mil. Em 2002, eram 3.064 firmas nesta faixa. No ano seguinte, foram 3.323, totalizando 259 empresas a mais. Outro crescimento significativo foi verificado na faixa entre US\$ 1 bilhão e US\$ 2 bilhões: o número de firmas passou de 957 para 1.093.

Mesmo após a crise de confiança que o país sofreu em 2002, a inflação é controlada, as exportações sobem e a economia cresce em ritmo moderado. Tudo isso contribuiu para a melhora significativa das exportações neste período referentes ao período anterior.

Entre 2007 a 2009, as exportações variaram negativamente. Concerteza, esse problema foi decorrente da crise mundial que começou nos Estados Unidos e acabou afetando todo o mundo, que levou dezenas de empresas à falência, e milhares outras a retrair seus gastos, cortando funcionários e diminuindo a produção.

\section{EXPORTAÇÃO DO RIO GRANDE DO NORTE}

Tendo em vista, as oscilações da economia que vem ocorrendo desde 2002, muitas empresas foram estimuladas e desestimuladas neste tempo, inclusive no Rio Grande do Norte. Para melhor visualização da informação, o quadro 6 contém o número das empresas existentes no RN e o respectivo ano. 


\begin{tabular}{|l|l|}
\hline Ano & Número de Empresas \\
\hline 2001 & 86 empresas \\
\hline 2002 & 89 empresas \\
\hline 2003 & 105 empresas \\
\hline 2004 & 113 empresas \\
\hline 2005 & 128 empresas \\
\hline 2006 & 140 empresas \\
\hline 2007 & 137 empresas \\
\hline 2008 & 122 empresas \\
\hline
\end{tabular}

Quadro 6 - Empresas Exportadoras do RN

Elaboração: a autora. Dados disponibilizados pelo MDIC/SECEX

No quadro 6, observa-se que desde 2001 o número de empresas aumentou significativamente até o ano de 2006. Porém, a partir desse ano até 2008, o número de empresas diminuiu em até mais de $10 \%$, o que considerado um número elevado, visto que mais de vinte e duas empresas deixaram de colaborar com a balança comercial do RN, e de movimentar a economia norte-rio-grandense.

Isso de fato pode ter sido influenciado pela crise que viria a estourar pouco tempo mais tarde, em 2008 e que desde 2001, por meio de uma política de juros baixíssimos e de redução dos encargos financeiros, o banco central norte-americano (FED), encorajou os intermediários financeiros e imobiliários a estimular uma clientela cada vez maior a investir em imóveis. Instaurou-se assim o sistema dos subprimes, empréstimos hipotecários de risco e taxa variável oferecidos às famílias mais frágeis. Mas, em 2005, ao aumentar as taxas de juros (estas mesmas que acabou de reduzir), o FED detonou a máquina e provocou um efeito dominó que, a partir de agosto 2007, fez vacilar o sistema bancário internacional Assim sendo, os EUA por representarem o centro da economia mundial, e por ser detentor de uma moeda forte - o dólar, acaba levando para a crise todo o mundo, afetando setores diversos da economia local.

Mas como a economia é sempre instável e depende de vários fatores que não somente a crise, e por conter muitas variantes, a balança comercial de um país geralmente passa por situações de estabilidade, assim como situações de desequilíbrio. Para entender um pouco sobre a economia do Rio Grande do norte, segue um histórico com a balança comercial local nos últimos anos.

\begin{tabular}{|c|c|c|c|c|c|}
\hline \multirow[t]{2}{*}{ ANO } & \multicolumn{2}{|c|}{ EXPORTAÇÃO } & \multicolumn{2}{|c|}{ IMPORTAÇÃO } & \multirow{2}{*}{$\begin{array}{l}\text { SALDO } \\
\text { (A) - (B) }\end{array}$} \\
\hline & VALOR & $\operatorname{LOR}(\%)$ & VALOR & VALOR (\%) & \\
\hline 1996 & 94.876 & $-4,40$ & 101.543 & $-20,51$ & -6.667 \\
\hline 1997 & 93.536 & $-1,41$ & 125.408 & 23,50 & -31.872 \\
\hline 1998 & 101.748 & 8,78 & 88.512 & $-29,42$ & 13.236 \\
\hline 1999 & 115.474 & 13,49 & 84.236 & $-4,83$ & 31.238 \\
\hline 2000 & 149.442 & 29,42 & 70.181 & $-16,68$ & 79.261 \\
\hline 2001 & 187.677 & 25,58 & 88.697 & 26,38 & 98.980 \\
\hline 2002 & 223.718 & 19,20 & 115.543 & 30,27 & 108.175 \\
\hline 2003 & 310.551 & 38,81 & 168.563 & 45,89 & 141.489 \\
\hline 2004 & 573.836 & 84,78 & 139.486 & $-17,25$ & 434.350 \\
\hline 2005 & 413.712 & $-27,90$ & 110.335 & $-20,90$ & 303.376 \\
\hline
\end{tabular}




\begin{tabular}{|l|l|l|l|l|l|}
\hline 2006 & 372.011 & $-10,08$ & 130.450 & 18,23 & 241.560 \\
\hline 2007 & 300.975 & $-19,09$ & 122.436 & $-6,14$ & 178.539 \\
\hline 2008 & 348.091 & 15,65 & 207.210 & 69,24 & 140.881 \\
\hline
\end{tabular}

Quadro 7 - Histórico da Balança Comercial do RN (US\$ 1.000 FOB)

Elaboração: a autora. Dados disponibilizados pelo MDIC/SECEX, sistema ALICE WEB.

Como se pode observar, o quadro 7 contém um demonstrativo da balança comercial do Rio Grande do Norte desde 1996. É possível analisar com as tabelas anteriores que o Brasil possui um histórico de relações internacionais relativamente estáveis, porém, havendo momentos de grandes saldos econômicos, assim como também momentos de déficits. No estado do Rio Grande do Norte não é diferente, visto os dados da acima.

Tendo como pontos de referência, o valor das mercadorias, assim como o peso líquido e a quantidade destas, o quadro 8 contém os dez principais países importadores dos produtos norte rio-grandense.

\begin{tabular}{|l|l|l|l|}
\hline País & US\$ (FOB) & Peso Líquido $($ KG) & Quantidade \\
\hline EUA & 1.027 .995 .120 & 3.059 .164 .689 & 151.989 .258 \\
\hline Holanda & 332.001 .853 & 573.134 .485 & 49.438 .764 \\
\hline Reino Unido & 306.184 .191 & 684.623 .626 & 9.830 .642 \\
\hline Trinidad e Tobago & 303.144 .953 & 1.138 .227 .301 & 1.303 .944 \\
\hline Espanha & 227.628 .704 & 237.017 .565 & 2.226 .797 \\
\hline França & 186.988 .904 & 50.127 .490 & 1.103 .700 \\
\hline Nigéria & 107.636 .296 & 4.224 .700 .931 & 3.458 .739 \\
\hline $\begin{array}{l}\text { Ilhas } \\
\text { (Britânica) }\end{array}$ & 106.911 .544 & 483.045 .333 & 554.168 \\
\hline Argentina & & & 14.153 .979 \\
\hline Itália & 102.621 .558 & 112.185 .768 & 1.472 .209 \\
\hline
\end{tabular}

Quadro 8 - Os Dez Maiores Importadores do RN (1996-2008)

Fonte: Elaboração da autora. Dados disponibilizados pelo MDIC/SECEX, sistema ALICE WEB.

É possível observar que no quadro 8 encontram-se novos países que não constaram no quadro 8 como maiores destino das exportações do RN. Isso porque, em 2004, Trinidad e Tobago e Ilhas Virgens (Britânicas) foram os principais importadores, com US\$ 172.665.995 e US\$ 92.631.993, ou seja, quase o Trinidad e Tobago com quase $50 \%$ das importações nos últimos dez anos, e as Ilhas Virgens com a participação de $90 \%$ só em 2004, o que explica a inclusão destes no grupo de dez maiores importadores dos últimos anos.

Segundo dados do MDIC/SECEX, no Sistema AliceWeb, a mercadoria importada por Trinidad E Tobago, foi - óleos brutos de petróleo, o que explica o alto valor no ano de 2004 e a participação deste país no grupo de dez maiores importadores. Assim como nas Ilhas Virgens (Britânicas), que também importou óleos brutos de petróleo, o que o inclui do mesmo modo neste grupo.

Segundo dados da Assessoria de Comunicação do Governo do Estado do RN (ASSECOM), o estado do RN é o que mais cresce no Comércio Exterior. A assessoria afirma que, o bom desempenho do comércio exterior do Estado está na diversidade da 
economia exportadora, da agricultura tradicional, com as frutas, passando pelo camarão, ao setor industrial, da confecção à alimentação, sem esquecer o setor mineral, com o granito.

\section{METODOLOGIA}

A presente pesquisa visou analisar as empresas exportadoras do Estado do Rio Grande do Norte, com o objetivo de definir o perfil dessas empresas, entendendo a necessidade por suporte e consultoria, como também estudar a inserção dos alunos do Curso de Tecnologia em Comércio Exterior do Instituto Federal de Educação, Ciências e Tecnologia do RN (IFRN). A metodologia escolhida foi do tipo exploratório-descritiva, utilizando-se de dados secundários, como também de pesquisas bibliográficas e em meio eletrônico.

Segundo Mattar (1996), uma pesquisa exploratória visa promover o pesquisador de maior conhecimento sobre o tema ou pesquisa em perspectiva. Segundo ele, isso permite conhecer de maneira mais profunda o assunto para estabelecer melhor o problema, para que se possa desenvolver hipóteses explicativas para os fatos e fenômenos a serem estudados.

\section{TIPO DE PESQUISA}

Como dito anteriormente, a presente pesquisa caracterizou-se como exploratóriodescritiva, que segundo Alexandre (2003), visa desenvolver, esclarecer e modificar conceitos e idéias; envolve levantamento bibliofigura e documental, e entrevistas. Com isso, este trabalho contém pesquisas bibliográficas, bem como, uma análise da conjuntura social e econômicas das empresas exportadoras do Estado.

\section{UNIVERSO E AMOSTRA}

O universo desta pesquisa envolveu, conforme pesquisa exploratória, as empresas exportadoras do RN, que segundo dados do MDIC/SECEX, no ano de 2008 eram 122 empresas exportadoras em todo o Estado.

A amostra da pesquisa constituiu-se de empresas que se localizam em Natal e Região Metropolitana, que engloba os municípios de Parnamirim, Macaíba, São Gonçalo do Amarante e Ceará Mirim. O número de empresas que residem nessas regiões soma 59 empresas.

\section{COLETA DE DADOS}

Os dados aqui apresentados foram coletados em pesquisas bibliográficas, bem como em pesquisas na internet, e principalmente informações coletadas junto aos representantes das empresas exportadoras através de questionários aplicados nas respectivas instituições, que é o indicador mais representativo da pesquisa. 
Alguns portais foram de fundamental importância para a conclusão desse projeto. Portais como AliceWeb, portal do MDIC/SECEX, Radar Comercial, Brazil Trade Net, entre outros, que são portais do governo e que possuem dados confiáveis para a otimização do presente trabalho.

Com os dados coletados, foi realizada a junção desses dados a fim de melhor analisá-los; e para isso foi usado um software de apoio estatístico - o SPSS, com o objetivo de atingir o melhor entendimento possível. Em seguida, realizou-se a editoração dos figuras e tabelas, a nível estético e de organização, para o melhor aproveitamento da pesquisa.

\section{PESQUISA DE OPINIÃO EM EMPRESAS EXPORTADORAS DE NATAL E REGIÃO METROPOLITANA}

Esta seção vai tratar da pesquisa de opinião realizada para o referido trabalho, procurando explicar como foi desempenhada a coleta dos dados e os principais resultados obtidos com a realização da pesquisa de opinião.

\section{DESCRIÇÃO DA COLETA}

Atualmente, segundo dados do Ministério de Desenvolvimento, Indústria e Comércio e Secretaria de Comércio Exterior de 2009, o estado do Rio Grande do Norte conta com 122 (cento e vinte e duas) empresas exportadoras, dividas entre os municípios de Açu, Areia Branca, Arês, Baia Formosa, Baraúna, Ceará Mirim, Currais Novos, Felipe Guerra, Galinhos, Grossos, Ipanguaçu, Jandaíra, Macaíba, Macau, Maxaranguape, Mossoró, Natal, Parelhas, Parnamirim, Porto do Mangue, São Bento do Norte, São Gonçalo do Amarante, São José do Mipibu, São Miguel do Gostoso, São Paulo do Potengi, Serra do mel, Tibau do Sul, Touros e Upanema.

Outrossim, durante o trabalho de coleta dos dados, que ocorreu no período de 14 de maio de 2009 até 17 de junho de 2009, foi constatado que das cinqüenta e nove Empresas Exportadoras que compunham a amostra, três destas exportam por outros Estados, e cinco Empresas fecharam. Portanto, o número de Empresas a serem entrevistadas passou a ser 51.

É importante compreender que a coleta dos dados foi delineada de acordo com a localização das empresas exportadoras na região da Grande Natal (MDIC/SECEX, 2009), como mostra a figura 7. Um outro aspecto a ser destacado é que a composição da amostra por cidades, segue de certo modo a metodologia costumeiramente utilizada para Pesquisas de Opinião em Natal (CERTUS, 2008; CONSULT, 2008), as quais sempre estratificam o conjunto de dados a ser entrevistado por vários critérios, um dos quais a estratificação é por região administrativa, no caso de Natal. 


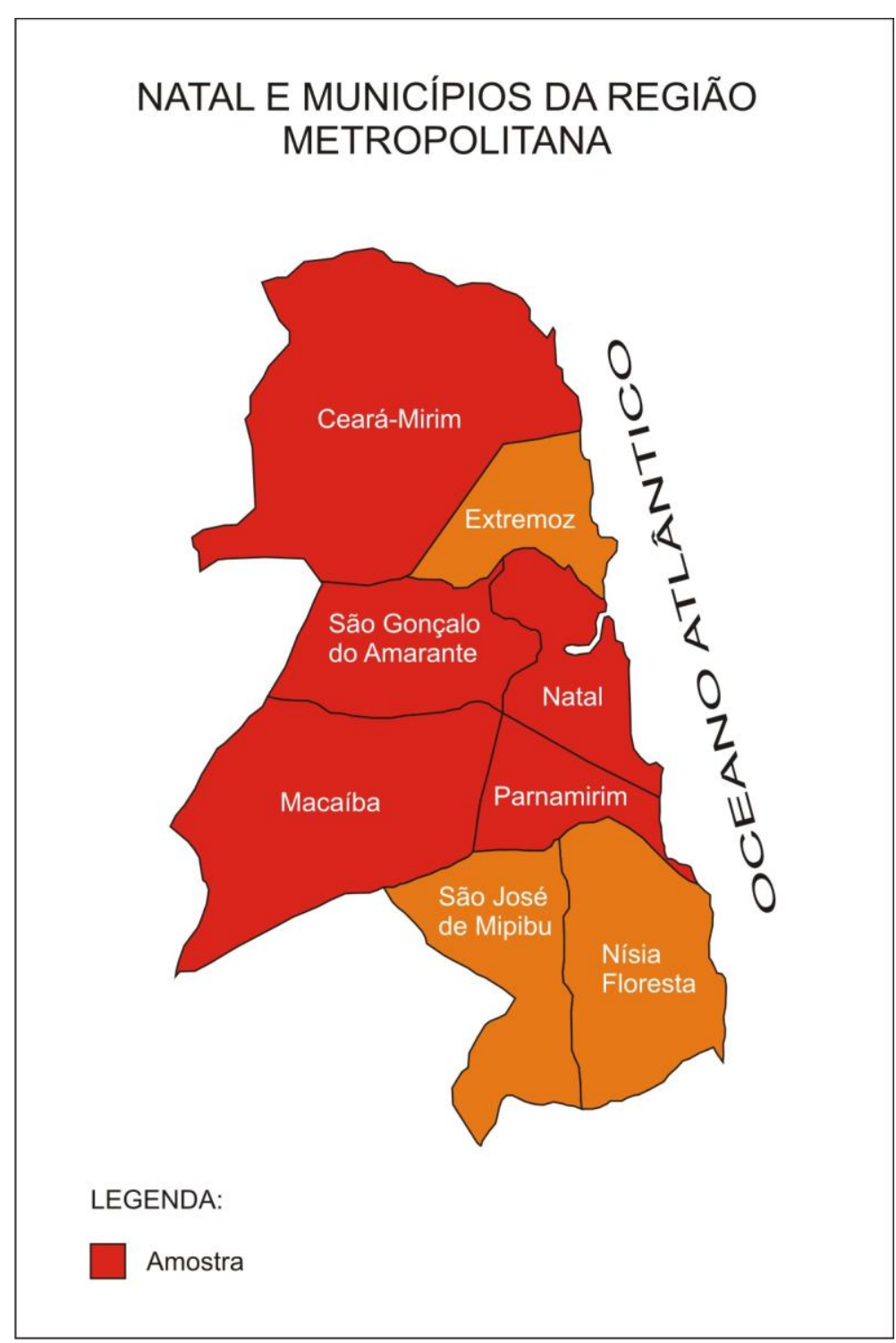

Figura 7 - Mapa da região metropolitana de Natal.

Fonte: Pesquisa de Opinião, 2009. Elaboração: a autora.

Como pode-se observar na figura 7, a amostra da pesquisa constitui-se dos municípios de Ceará Mirim, São Gonçalo do Amarante, Natal, Macaíba e Parnamirim. Somente esses municípios concentram quase $50 \%$ das empresas de todo o Estado. Isso porque, possuem uma localização mais estratégia por estarem perto da capital do Estado (Natal), e por se localizarem ao redor do aeroporto internacional que se localiza no município de Parnamirim.

Como já foi supramencionado, o número das Empresas desses municípios é de 51 (cinquienta e uma) empresas exportadoras, que serão detalhadas na figura 8 , de acordo com cada município. 


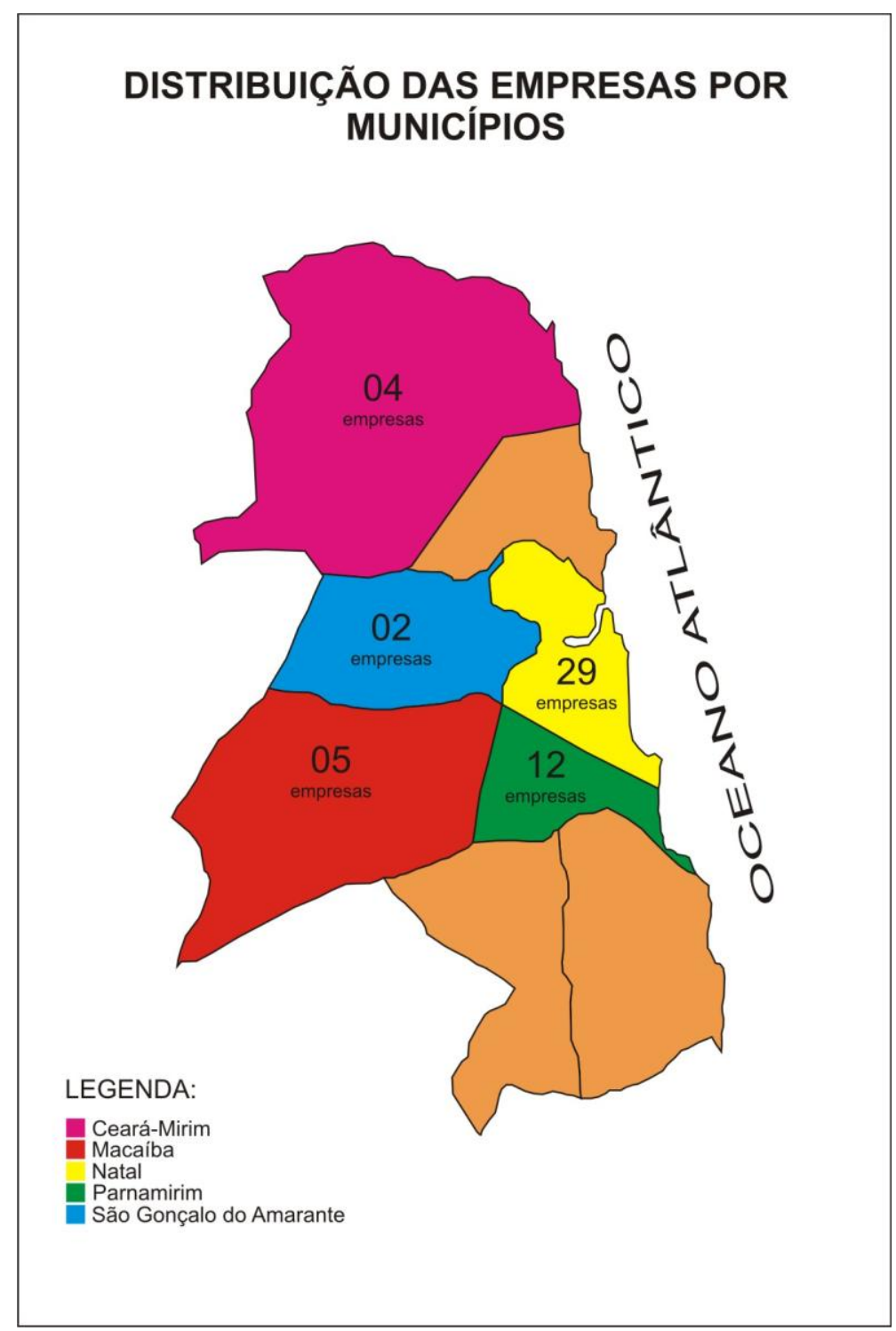

Figura 8 - Mapa de Divisão de Empresas por Município. Fonte: Pesquisa de Opinião, 2009. Elaboração: a autora.

De acordo com o figura 8, as empresas estão divididas por município. É possível analisar que no município de Natal contém o maior número de empresas da amostra com 29 (vinte e nove) empresas, seguido por Parnamirim com 12 (doze), Macaíba com 05 (cinco), Ceará Mirim com 04 (quatro) e São Gonçalo do Amarante com apenas 2 (duas).

Como em qualquer outra pesquisa de opinião, houve um número de questionários não respondidos, o que é normal, visto que a quantidade de empresas que responderam estão dentro da margem esperada que é em torno de $20 \%$ (Junckes, 1996).

Na presente pesquisa, a taxa de retorno dos questionários respondidos foi de 39,22\%. Isso porque, das cinqüenta e nove empresas previstas para serem entrevistadas, três destas exportam por outro estado e cinco empresas fecharam, logo, estas não fazem mais parte da amostra; e 31 não responderam ao questionário. Logo, foram entrevistadas 20 empresas.

Detalhando a quantidade de empresas que responderam e que não responderam. A figura 9, contém a distribuição de empresas no município de Macaíba. 


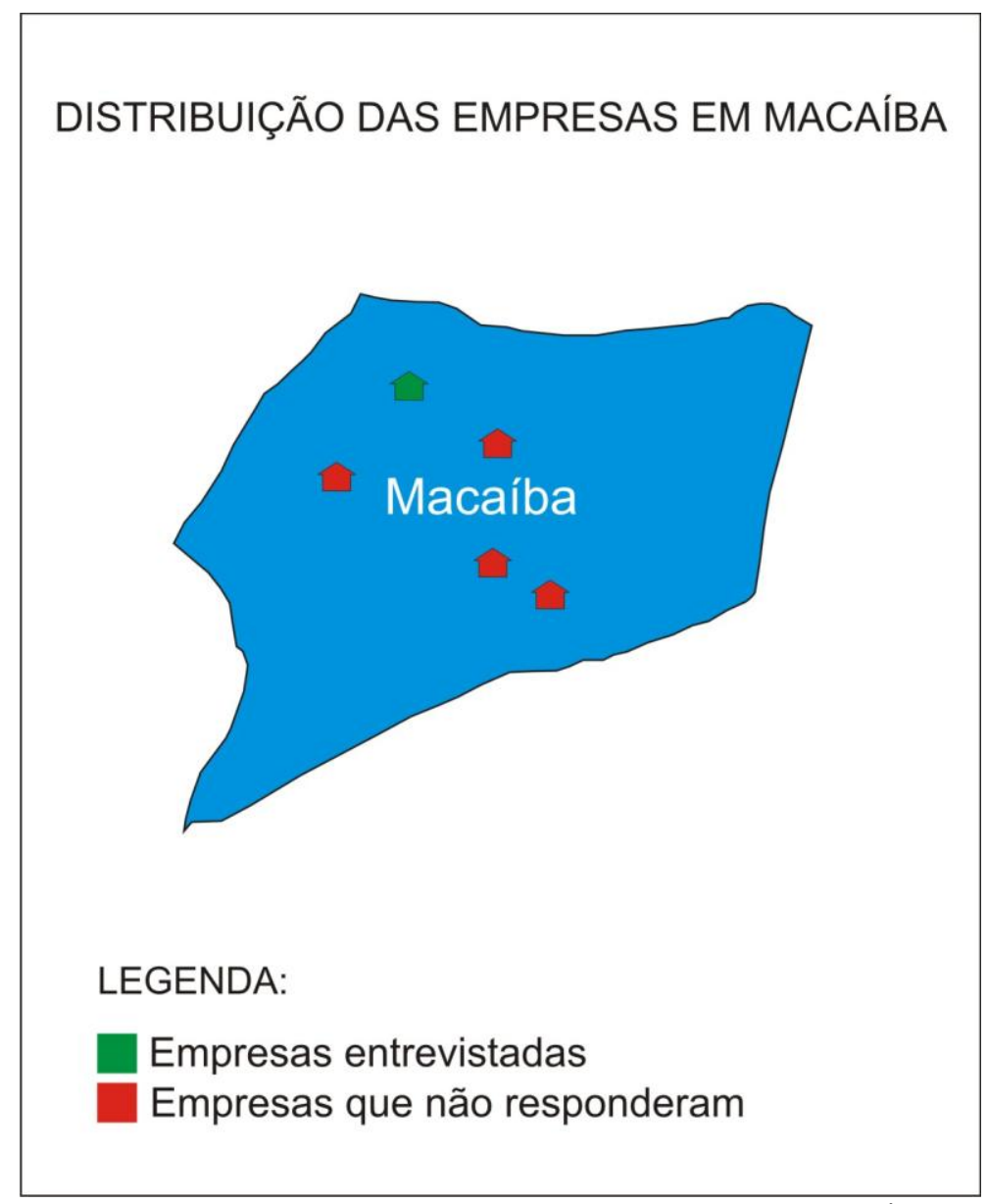

Figura 9 - Mapa de Distribuição das Empresas em Macaíba. Fonte: Pesquisa de Opinião, 2009. Elaboração: a autora.

A figura 9, mostra as empresas exportadoras no município de Macaíba. Como pode-se observar a cidade conta com cinco empresas exportadoras. Destas apenas uma respondeu ao questionário aplicado; as outras quatro não responderam. A figura 10, visualiza o município de Parnamirim, com as respectivas empresas que compunham a amostra no município. 


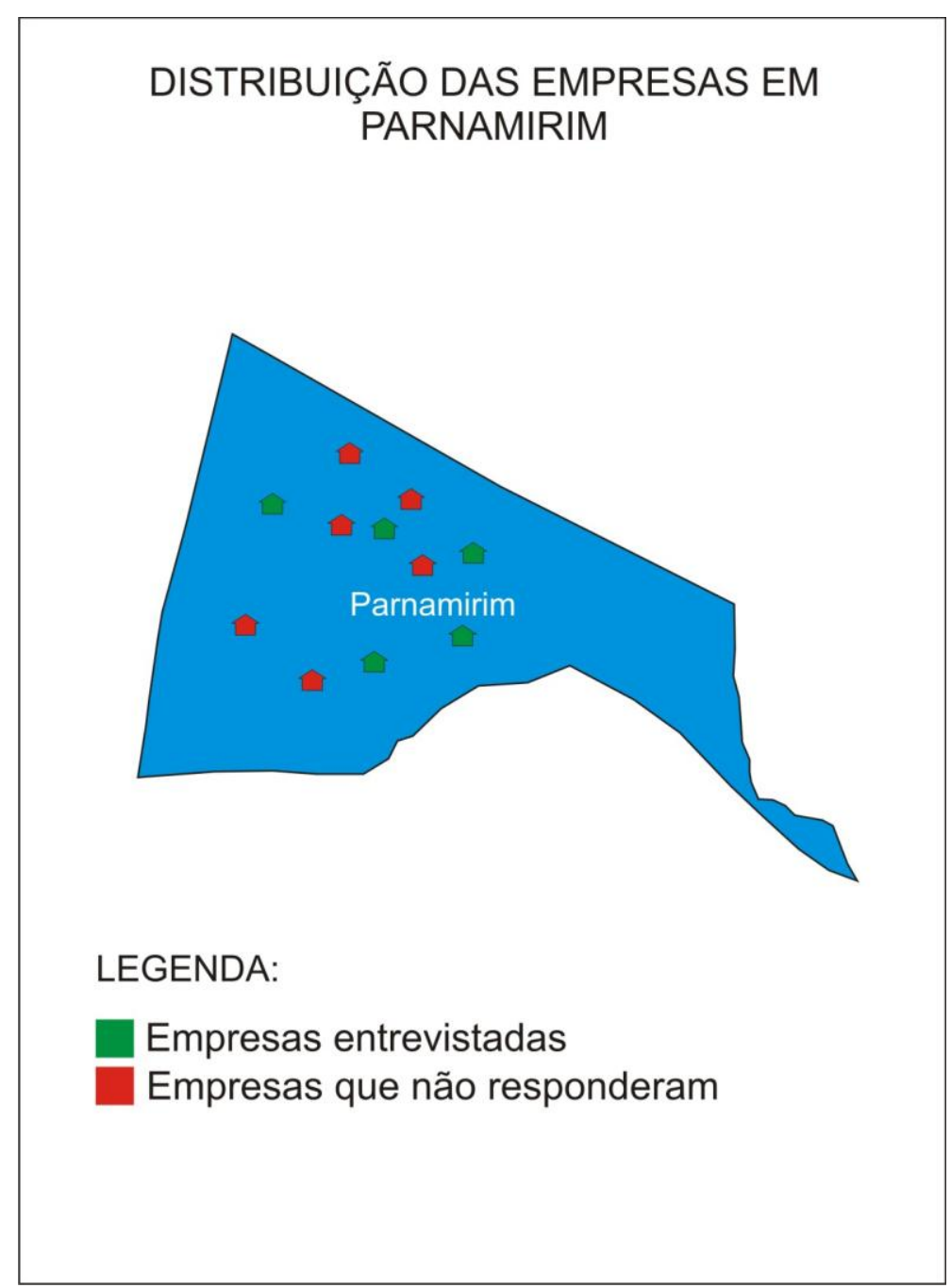

Figura 10 - Distribuição das empresas em Parnamirim. Fonte: Pesquisa de Opinião, 2009. Elaboração: a autora.

Como pode ser observado na figura 10, o município de Parnamirim é composto por doze empresas exportadoras, o segundo maior município representativo da amostra. Segundo a figura 10, das doze empresas previstas na amostra para serem entrevistadas, cinco destas foram entrevistadas, e seis empresas não responderam ao questionário.

A figura 11, apresenta as empresas do município de São Gonçalo do Amarante. 


\section{DISTRIBUIÇÃO DAS EMPRESAS EM SÃO} GONÇALO DO AMARANTE

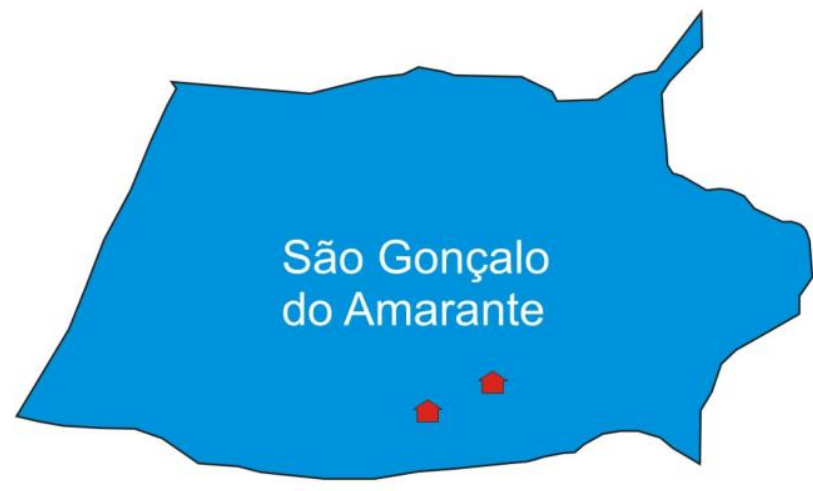

\section{LEGENDA:}

\section{Empresas entrevistadas}

Empresas que não responderam

Figura 11 - Mapa de Distribuição das Empresas em São Gonçalo do Amarante.

Fonte: Pesquisa de Opinião, 2009. Elaboração: a autora.

Na figura 11, no município de São Gonçalo do Amarante, localizam-se duas empresas exportadoras do Estado. Não houve resposta do questionário nas duas referidas empresas. Na figura 12, faz referência ao município de Ceará Mirim, e as empresas localizadas nessa região. 


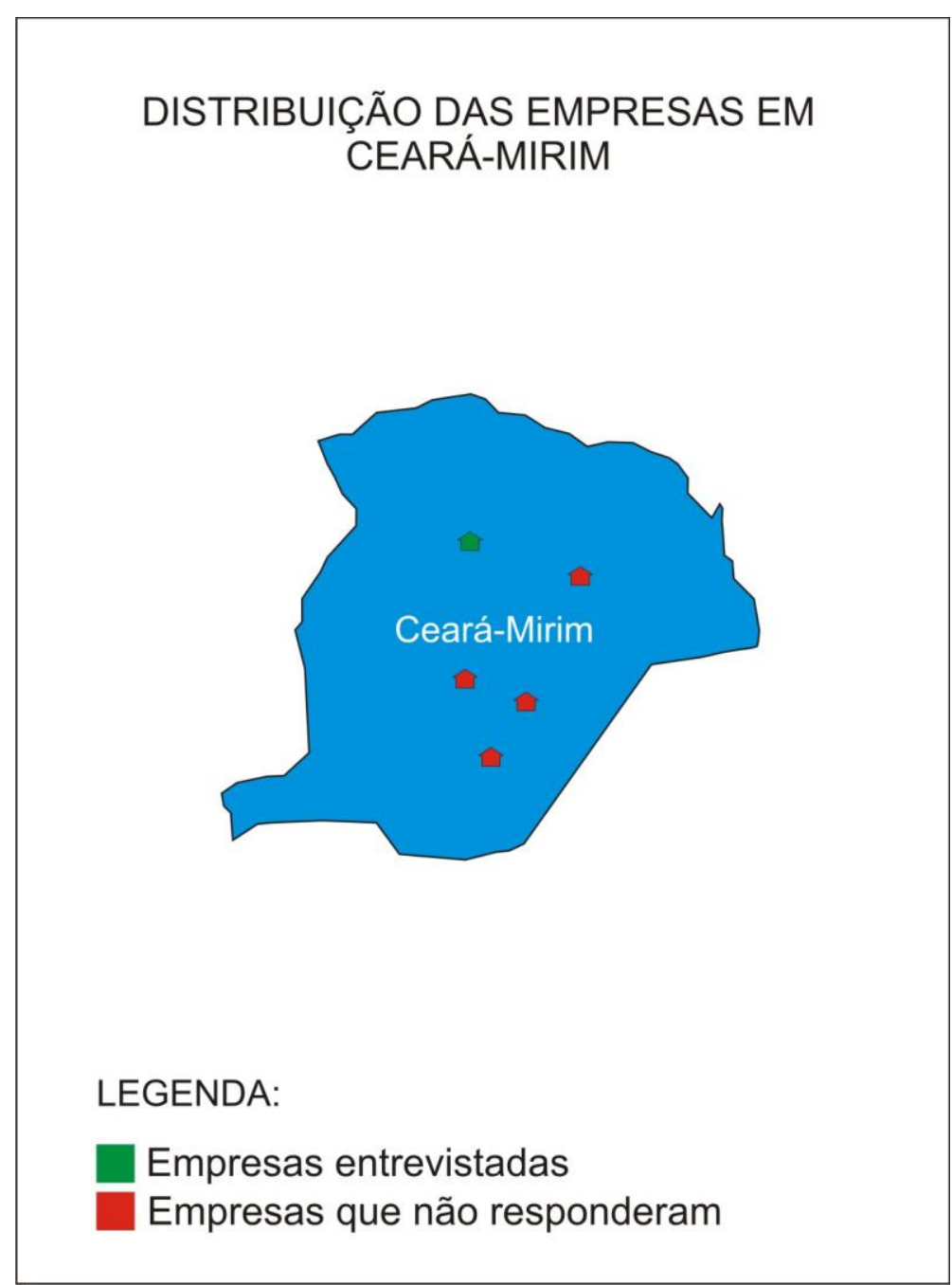

Figura 12 - Distribuição das empresas em Ceará Mirim.

Fonte: Pesquisa de Opinião, 2009. Elaboração: a autora.

A figura 12, contém as empresas de Ceará Mirim. Das cinco empresas do estado, apenas uma respondeu ao questionário; nas outras quatro, não foi obtida nenhuma resposta quanto à aplicação do questionário.

A figura 13, refere-se ao município de Natal, que está dividido por regiões administrativas: norte, sul, leste e oeste. Como é possível observar na figura 13, as empresas foram divididas pelas regiões à fim de permitir um conhecimento intenso da amostra do município. 


\section{DIVISÃO DAS EMPRESAS POR REGIÃO EM NATAL}

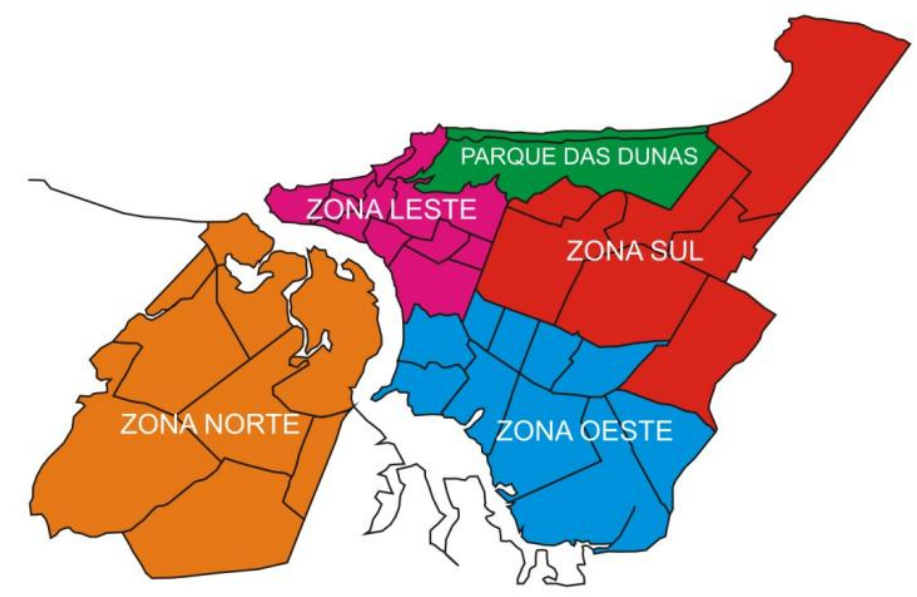

04 empresas responderam e 06 empresas não responderam.

09 empresas responderam e 04 empresas não responderam.

01 empresa respondeu e 04 empresas não responderam.

00 empresas responderam e 02 empresas não responderam.

Figura 13 - Mapa de Distribuição das Empresas em Natal, por regiões administrativas. Fonte: Pesquisa de Opinião, 2009. Elaboração: a autora.

De acordo com a figura 13, a região Sul contém onze empresas. Destas onze, quatro empresas foram visitadas, e seis empresas não responderem ao questionário.

Já na região Norte, apenas duas empresas estão situadas na região, e nenhuma respondeu ao questionário da pesquisa.

A região Leste, é responsável pelo agrupamento de treze empresas exportadoras. Esse número elevado de empresas agrupadas na região pode ser analisada partindo do princípio da localização geográfica, onde fica situado o porto de Natal, e grandes empresas do setor pesqueiro ficam localizadas na região. Das treze empresas, nove foram entrevistadas, e quatro não responderam ao questionário.

Já na região Oeste, localizam-se cinco empresas exportadoras. Destas cinco, apenas uma respondeu ao questionário. Das outras quatro, não foi obtido nenhum retorno referente à pesquisa.

\section{ANÁLISE QUANTITATIVA DOS DADOS OBTIDOS NAS EMPRESAS EXPORTADORAS DE NATAL E REGIÃO METROPOLITANA}

Nessa seção serão apresentadas as estatísticas descritivas das variáveis analisadas. Para isso, foi utilizado de um software de apoio estatístico - SPSS. A figura 14, apresenta a divisão das empresas por região administrativa. 


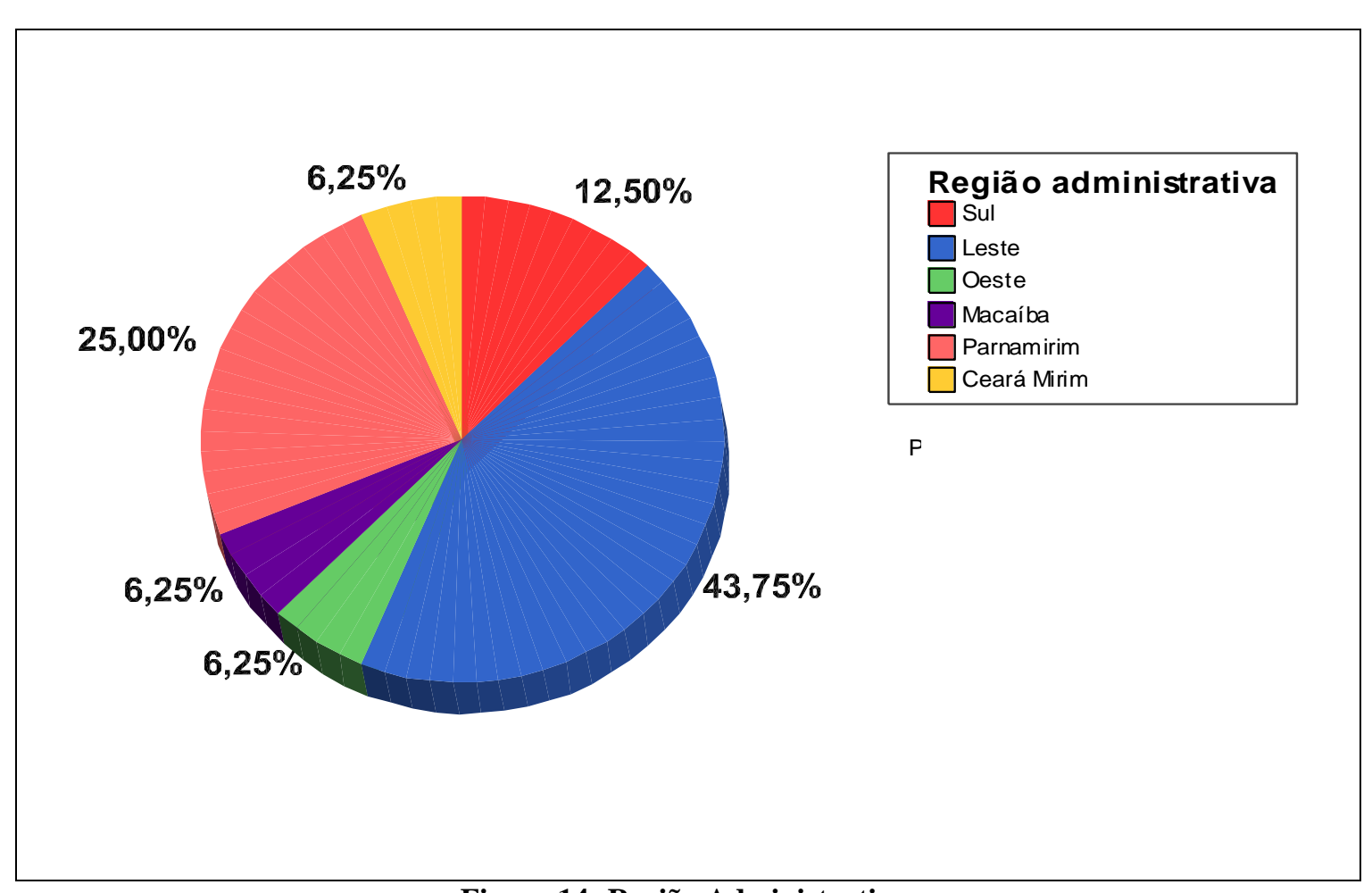

Figura 14: Região Administrativa.

Fonte: Pesquisa de opinião, 2009. Elaboração: a autora.

Como se pode observar a figura 14, as empresas foram dividas por regiões administrativas que eram compostas por Natal (Sul, Leste, Oeste), Macaíba, Parnamirim e Ceará Mirim.

Observa-se na figura 14, que o maior número de empresas entrevistadas encontram-se na zona Leste de Natal com 43,75\% de empresas, isso pode ser explicado pelo alto número de empresas do setor pesqueiro que se localizam nessa área, por se tratar de uma região estratégia para a execução dessa atividade econômica, por se localizar junto ao porto de Natal.

Outra região que se destacou entre as demais, foi o município de Parnamirim, representando $25 \%$ da amostra. Isso porque a região possui o Distrito Industrial, que é composta por grandes empresas, como o próprio nome diz. As demais regiões possuem uma distribuição uniforme de empresas, sem conter grandes aglomerações.

A figura 15, refere-se ao sexo dos entrevistados, que era compostos por diretores das empresas, presidentes ou gerentes, na maioria dele do setor de exportação da empresa. 


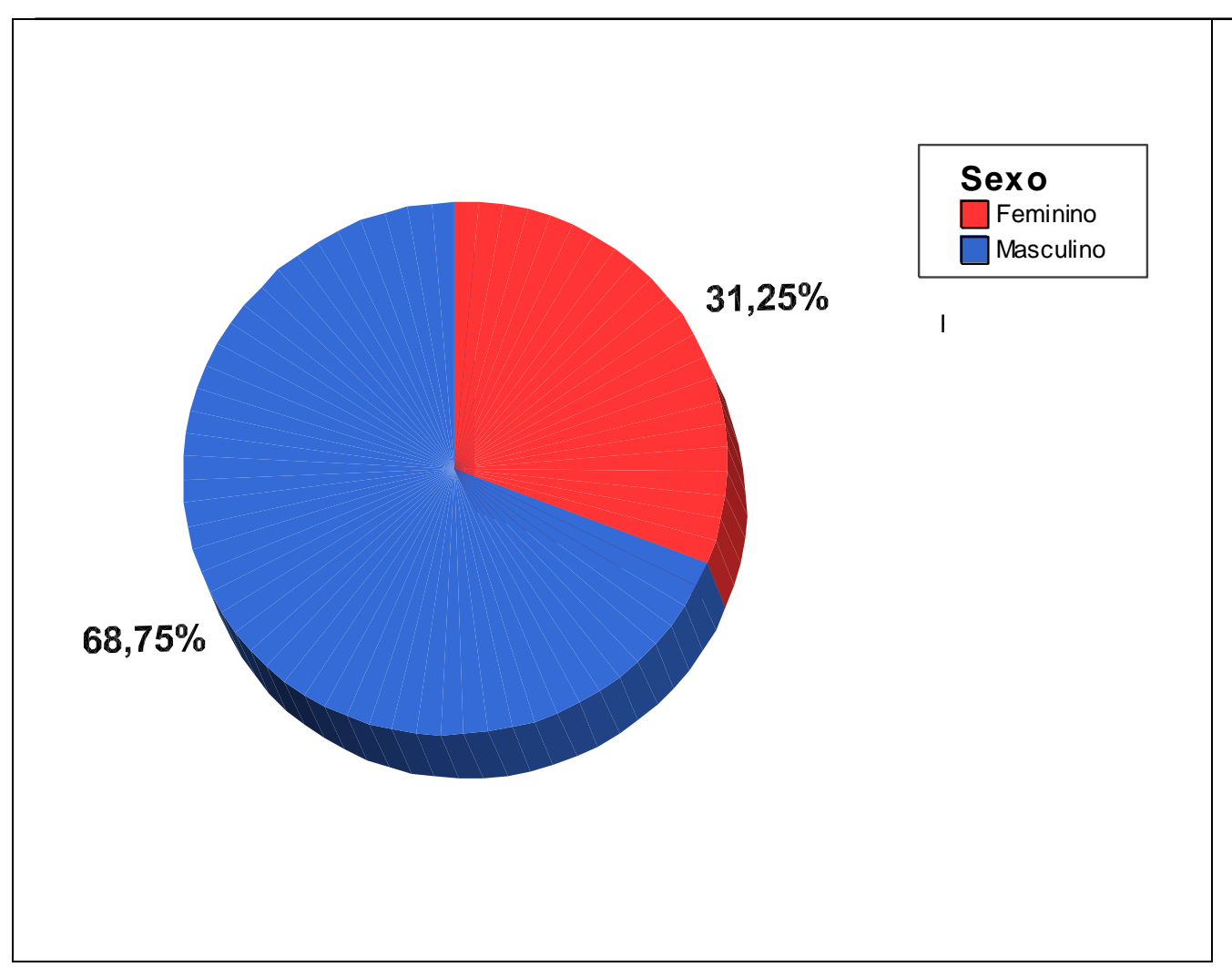

Figura 15: Sexo.

Fonte: Pesquisa de Opinião, 2009. Elaboração: a autora.

Pode-se observar na figura 15, que a maioria dos representantes da empresa são do sexo masculino, com quase $70 \%$ da amostra, o que nos revela uma realidade ainda antiga, onde geralmente os homens ainda possuem os cargos de mais confiança da empresa. As mulheres são detentoras de 31,25\% da amostra, um número razoável, mas ainda pouco significante frente ao profissional do sexo masculino.

Isso mostra que a tradição de muitos anos vem sendo passada durante os séculos, onde, a grande maioria de empresários são do sexo masculino, e que a população feminina é ainda marginalizada frente a esse tipo de profissional, mostrando uma visão ainda masculina e retrógrada desse tipo de pensamento.

A figura 16, contém o nível de escolaridade dos entrevistados, divididos em duas partes: segundo grau completo e terceiro grau completo. 


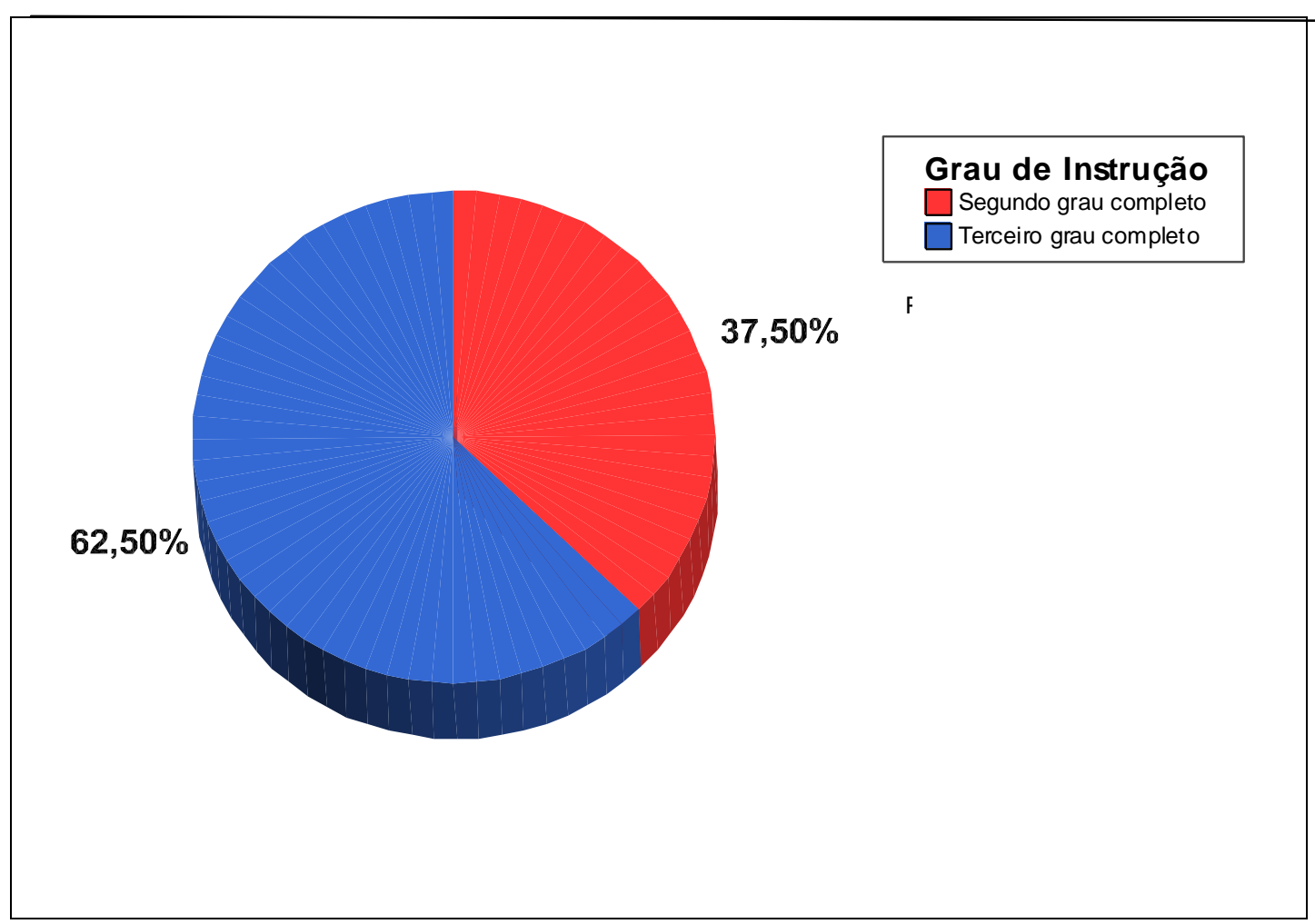

Figura 16: Nível De Escolaridade.

Fonte: Pesquisa de Opinião, 2009. Elaboração: a autora.

De acordo com a figura 16, $62 \%$ dos entrevistados possuíam o terceiro grau completo. E $37,50 \%$ possuíam apenas o segundo grau completo, um número relativamente alto, pois estes ocupam cargo de maior prestígio nas empresas, o que mostra uma realidade não muito satisfatória, visto que algumas dessas grandes empresas exportadoras não exigem uma formação superior, talvez por se tratarem de empresas familiares.

Atualmente, diante de um mercado competitivo, onde as empresas são mais exigentes e procuram um profissional cada vez mais qualificado e capacitado para as funções que exercerão nas empresas, é de se esperar que as empresas se adaptem a esse mercado mutável.Mas como é possível observar na figura 17, que essa ainda não é uma realidade total no mercado das empresas exportadoras do RN.

Na figura 17, observa-se a faixa etária dos respondentes do questionário. 


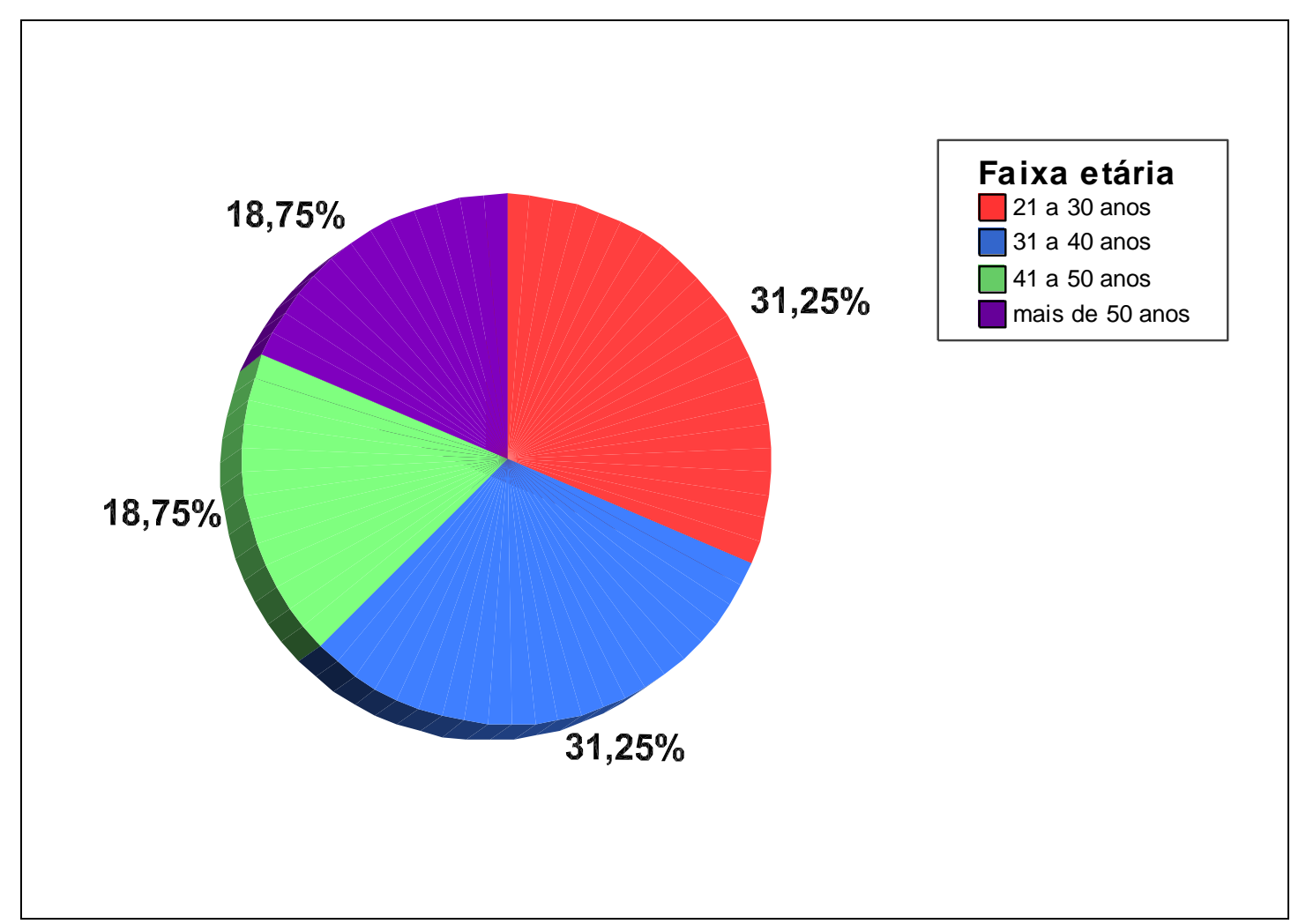

Figura 17: Faixa Etária.

Fonte: Pesquisa de Opinião, 2009. Elaboração: a autora.

Como se pode observar na figura 17 , os entrevistados foram divididos em quatro grupos. É possível observar que mais de $60 \%$ dos entrevistados possui menos de 40 anos. Lembrando que, esses entrevistados foram presidentes, diretores ou gerentes.; cargos que são de maior confiança em uma empresa. $\mathrm{O}$ que nos mostra que as empresas buscam pessoas capacitadas e não necessariamente que possuem uma experiência de vida maior, e a idade não influencia tanto, visto que um pouco mais de 30\% está acima de 41 anos.

O grande número de jovens nas empresas pode ser explicado pelo fato dos jovens de hoje em dia procurarem se capacitarem mais cedo, e muito mais rapidamente do que antigamente. E como mostra a figura acima, a maioria dos cargos de alta confiança da empresa ficam com as pessoas com até 40 anos.

A figura 18, nos permitirá analisar melhor este fato, visto que ele possui a divisão por cargos que o respondente exerce na empresa. 


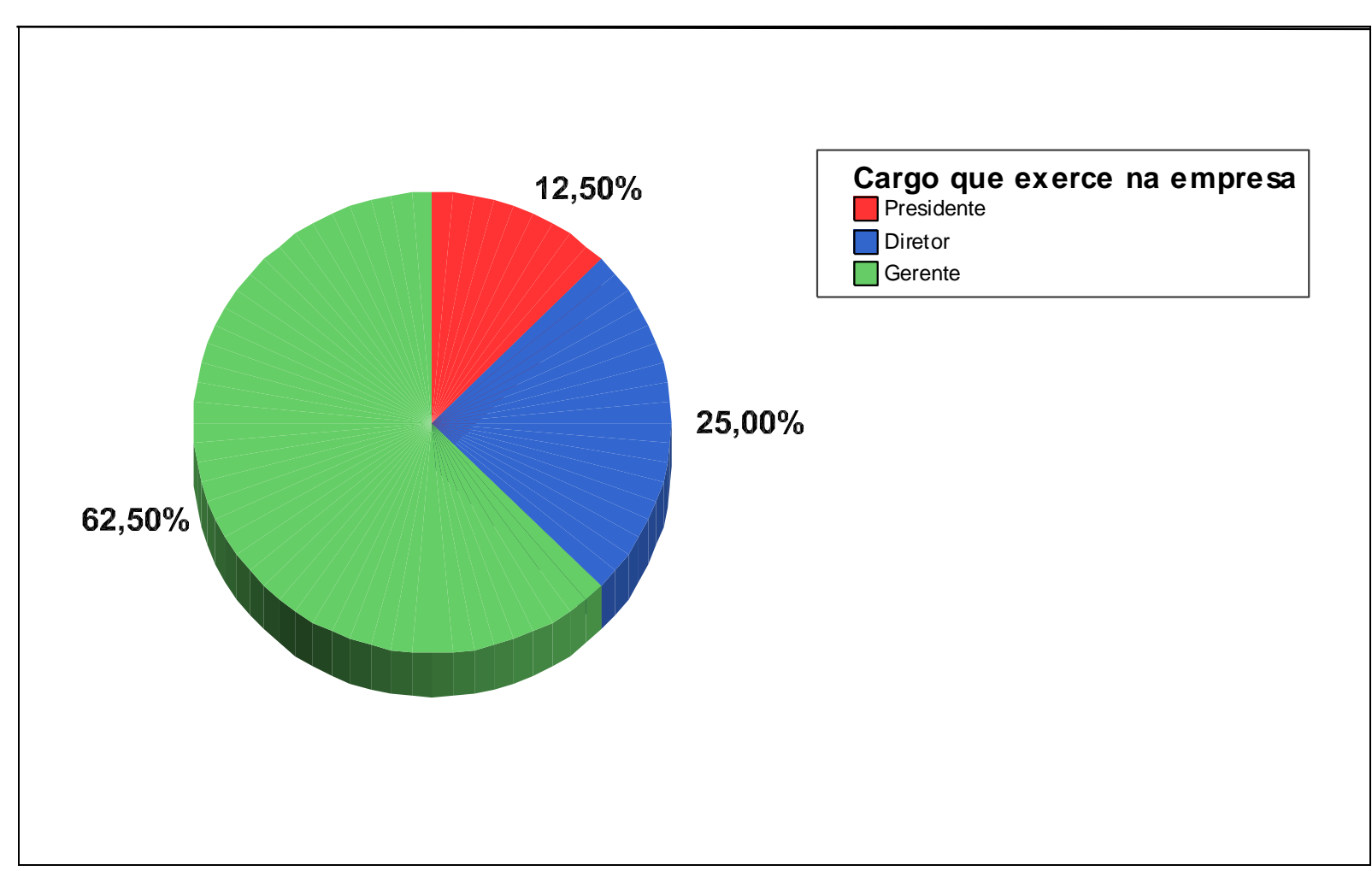

Figura 18: Cargo que Exerce na Empresa.

Fonte: Pesquisa de Opinião, 2009. Elaboração: a autora.

A figura 18 mostra o cargo que o entrevistado possui dentro da empresa. É possível observar que a maioria dos entrevistados foram os gerentes de lojas, representando $62,50 \%$ da amostra, $25 \%$ foram os diretores e apenas 12,50\%, presidentes das empresas exportadoras. Os gerentes entrevistados eram ou do setor de exportações das empresas ou do setor de logística.

A maioria dos entrevistados, como pode perceber na figura 18, são gerentes das empresas. Isso nos mostra o difícil acesso aos empresários do setor, principalmente nos níveis maiores como presidente. Ou seja, quanto maior prestígio o empresário tiver na empresa, mais difícil será ter acesso a esses empresários.

A figura 19, contém o porte das empresas exportadoras do RN que foram entrevistadas para atingir o objetivo desse trabalho. 


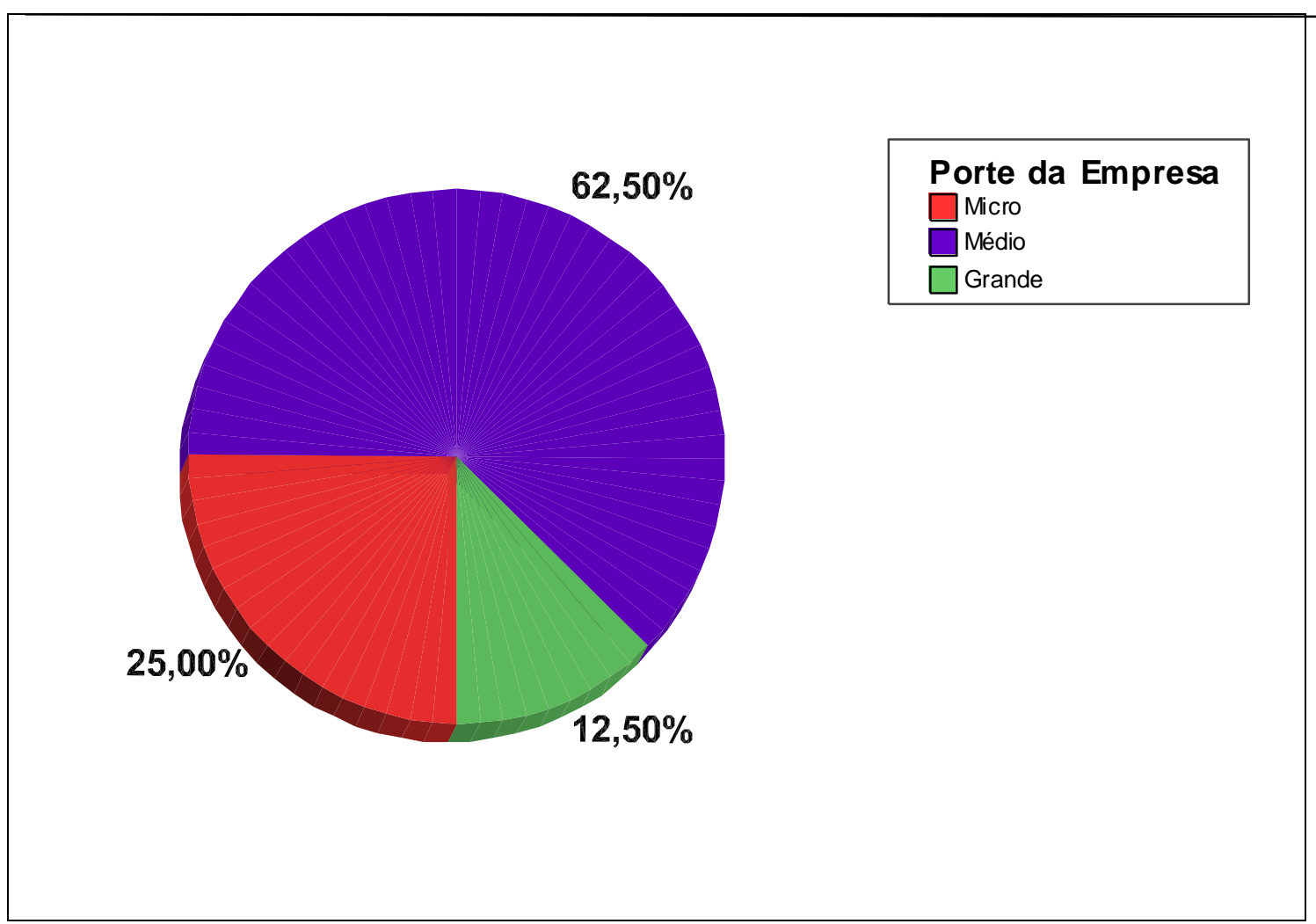

Figura 19: Porte da Empresa.

Fonte: Pesquisa de Opinião, 2009. Elaboração: a autora.

De acordo com a figura 19, a maioria das empresas entrevistadas eram de médio porte, representado por $62,50 \%$ da amostra. As empresas de médio porte constituem $25 \%$, e as de grande porte $12,50 \%$ das empresas pesquisadas.

Isso mostra a realidade empresarial do Estado, que é composto em sua maioria por empresas de micro, pequeno ou médio porte. As grandes empresas compõem a minoria representativa.

Pela sua privilegiada posição geográfica, situado na chamada 'esquina do continente', o RN destaca-se em diversas atividades, mas no setor industrial não há destaque. Talvez porque o Governo local não incentiva a migração de grandes empresas para o Estado.

Pela localização geográfica, o RN era para ser o destaque do país em pólo exportador, pela suas proximidades com a África e a Europa. Porém, isso não é o que acontece, principalmente no porto de Natal, que não possui a infra-estrutura necessária para atrair grandes empresas para o Estado.

A figura 20, mostra o número de funcionários das empresas pesquisadas, para comprovar as informações da figura 19. 


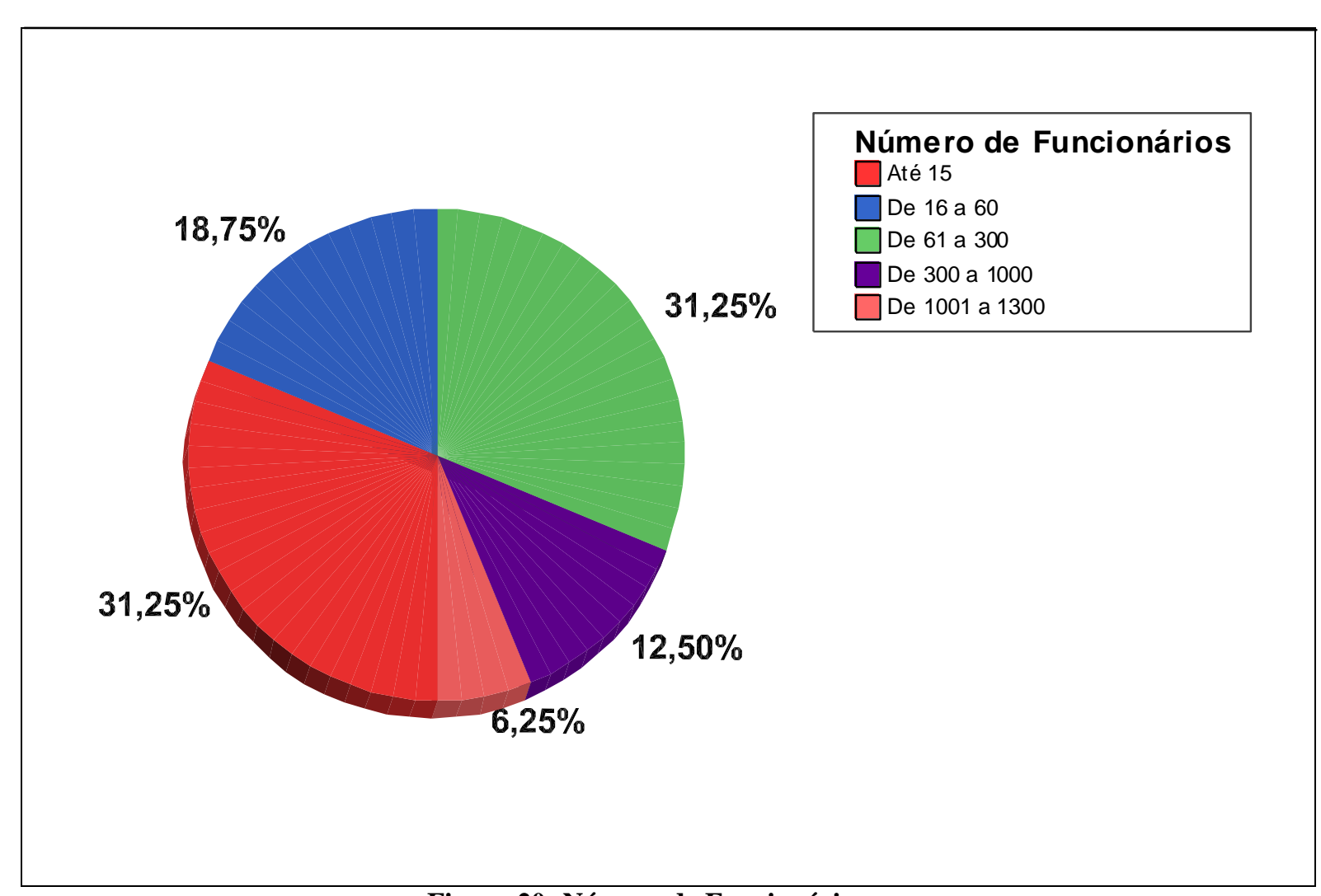

Figura 20: Número de Funcionários.

Fonte: Pesquisa de Opinião, 2009. Elaboração: a autora.

Com a figura 20, é possível analisar o número de funcionários das empresas exportadoras. Como se pode ver, $31 \%$ das empresas entrevistadas possuíam até 15 funcionários, o que mostra que para exportar a empresa não precisa ser de médio ou grande porte, basta ser consolidada, bem estruturada e ter interesse em se inserir no mercado internacional.

Ainda de acordo com a figura, 50\% da amostra possui de 16 até 300 funcionários, e apenas $18 \%$ da amostra possuem de 1001 a 1300 funcionários, logo é possível deduzir que estas são grandes indústrias e empresas exportadoras de grande porte.

De acordo a figura, a maioria das empresas possuem até 15 funcionários, ou de 61 a 300 funcionários. O que mostra, que tamanho nem porte são selecionadores quando se trata de acesso ao mercado internacional. 


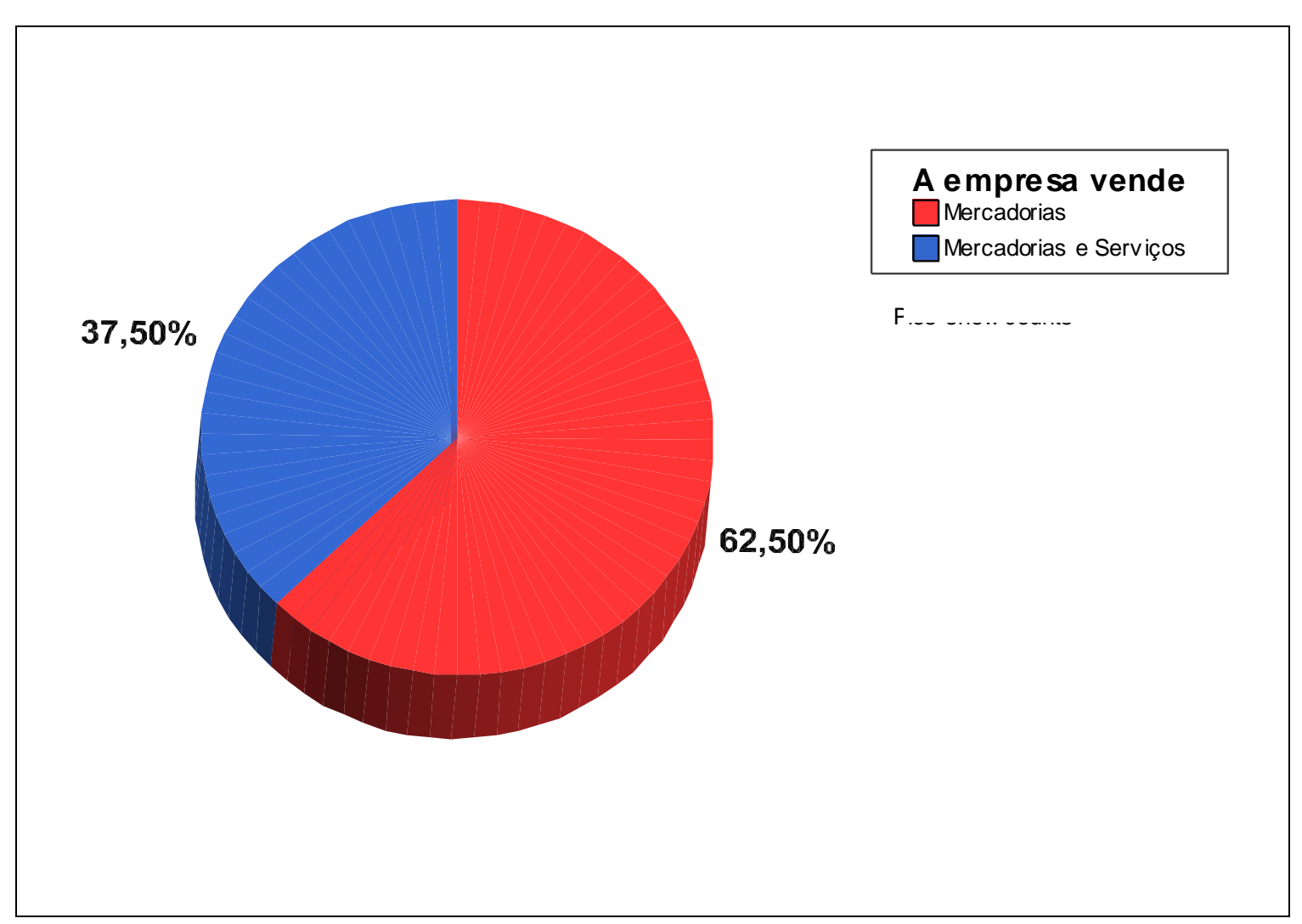

Figura 21: Comercialização da Empresa.

Fonte: Pesquisa de Opinião, 2009. Elaboração: a autora.

A figura 21, refere-se ao que as empresas entrevistadas comercializam. Como podemos observar, todas as empresas entrevistadas vendem mercadorias, ou seja, $100 \%$ das empresas. Porém, destas, apenas 37,50\% agregam algum tipo de serviço nos produtos que ofertam.

O que nos mostra que, os serviços não são grandes diferenciais quando se trata de mercado internacional, é preciso apenas que a empresa possua produtos de qualidade que sejam desejados pelos importadores. Ou seja, nenhuma empresa exportadora comercializa somente serviços, o que mostra que esse setor é muito escasso, principalmente no mercado externo. Pois as empresas se preocupam mais em oferecer produtos (físicos), uma vez que estes são mais fáceis de serem manipulados, e obter um controle maior sobre estes.

Diante desse quadro, o mercado de serviços é uma boa oportunidade de inserção no mercado externo, um grande campo a ser explorado, e conseguir um grande diferencial competitivo frente aos poucos concorrentes existentes no mercado. 


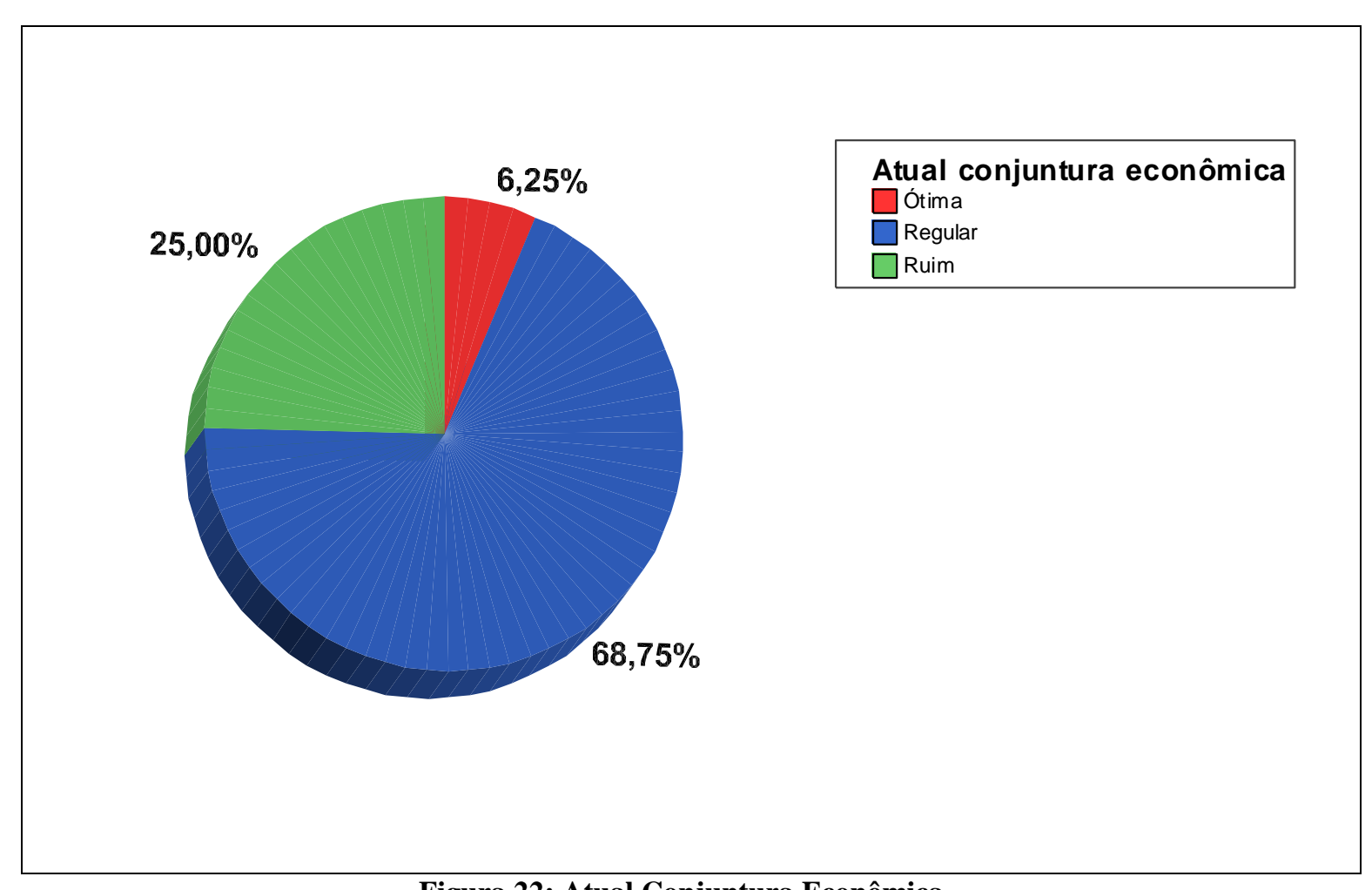

Figura 22: Atual Conjuntura Econômica.

Fonte: Pesquisa de Opinião, 2009. Elaboração: a autora.

Como pode-se observar a figura 22 mostra como os entrevistados vêem a atual conjuntura econômica: $75 \%$ dos entrevistados vêem a atual conjuntura econômica como regular ou ótima, e apenas $25 \%$ acham que o atual momento econômico é ruim.

Isso nos mostra que diante da crise mundial que assola o mundo nos últimos meses, ainda não afetou diretamente as empresas exportadoras norte-rio-grandenses. Com a figura 23, poderemos analisar como está a atual conjuntura econômica da empresa, em relação ao mercado, para entender melhor essa situação. 


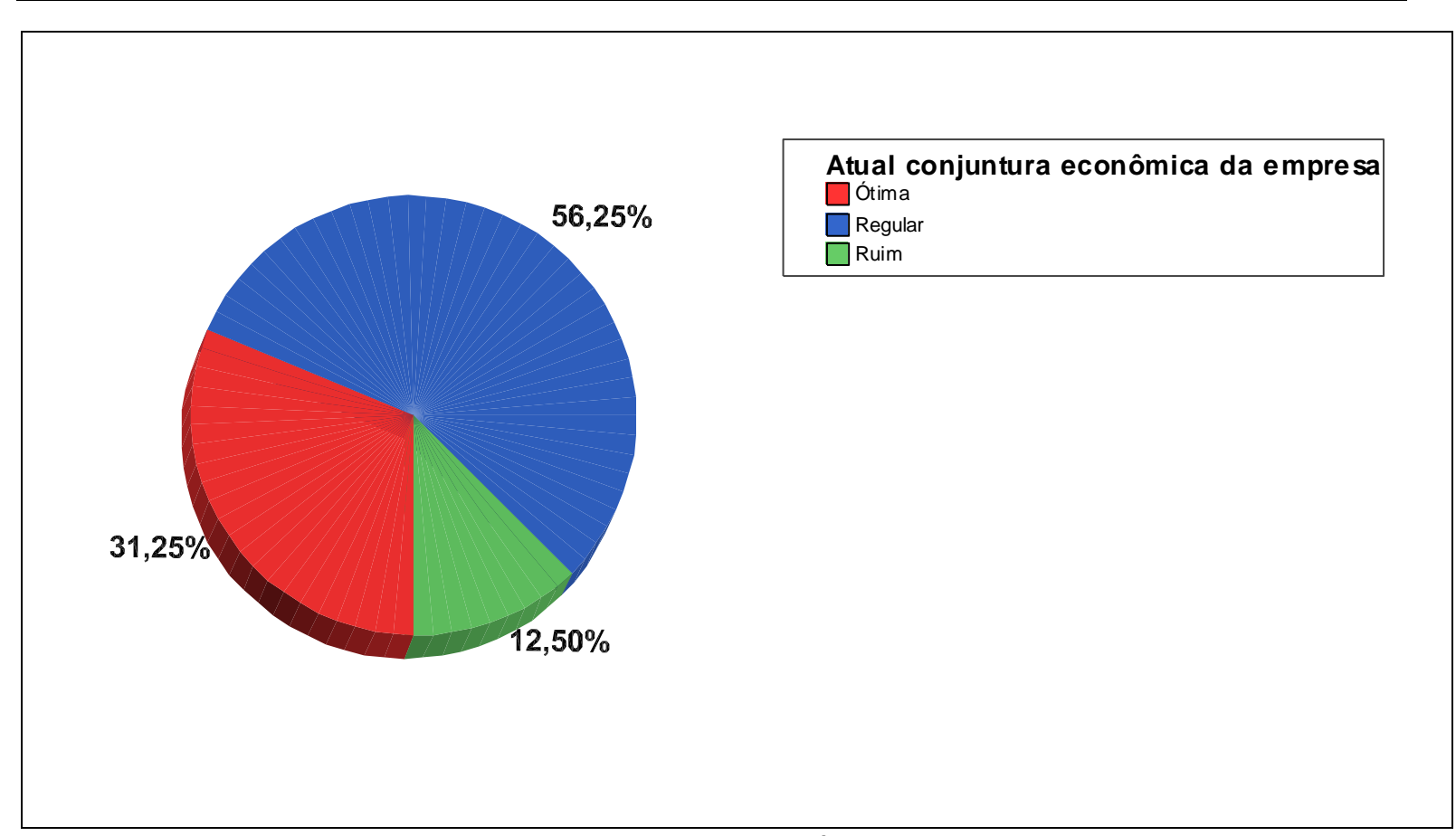

Figura 23: Atual Conjuntura Econômica da Empresa.

Fonte: Pesquisa de Opinião, 2009. Elaboração: a autora.

Analisando a figura anterior anterior, e a analisando a figura 23, é possível analisar que o desempenho da maioria das empresas exportadoras em relação ao mercado estão entre ótima e regular, com quase $90 \%$. Onde, $31,25 \%$ das empresas exportadoras entrevistadas vêem a atual conjuntura econômica da empresa como ótima, e 56,25\% como regular, e apenas $12,50 \%$ vêem a situação econômica da empresa como ruim.

Essa situação é um pouco contraditória diante do cenário mundial atual, visto que o mundo passa por uma crise econômica que está levando grandes empresas consolidadas no mundo todo à falência.

É ainda mais incrível ver a respostas dos entrevistados analisando pelo ângulo de que o maior importador dos produtos do Rio Grande do Norte são os Estados Unidos, país este que mais sofre com a crise mundial, principalmente pelo fato da crise ter surgido decorrente da crise imobiliária no país.

Analisando o mercado do $\mathrm{RN}$, e principalmente das empresas exportadoras, o Estado exporta bastantes produtos que podem ser considerados como supérfluo (como o setor de candies), e mesmo assim conseguem se sobressair diante a crise mundial, e manter as exportações. 


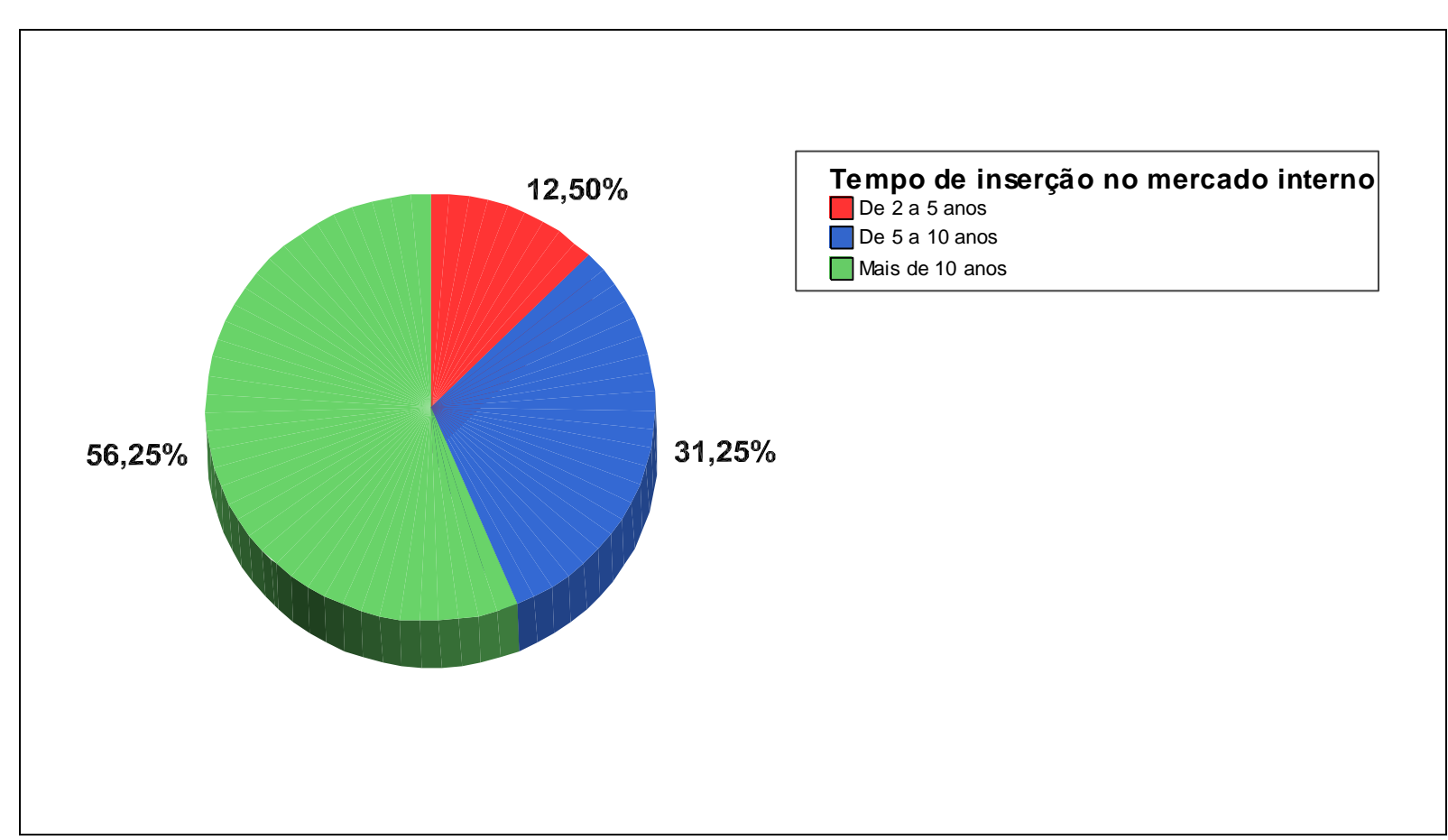

Figura 24: Tempo de Inserção no Mercado Interno.

Fonte: Pesquisa de Opinião, 2009. Elaboração: a autora.

A figura 24 nos permite visualizar há quanto tempo as empresas entrevistadas estão inseridas no mercado interno. Percebe-se que $56,25 \%$ já estão no mercado há mais de 10 anos, algumas delas chegando a ter até 60 anos de colocação no mercado.

Ainda segundo a figura, apenas $12,50 \%$ das empresas exportadoras possuem menos de 5 anos, e $31,25 \%$ destas empresas têm entre 5 e 10 anos de inserção no mercado nacional. $O$ que mostra que as empresas do RN são relativamente novas, pois quase $50 \%$ tem até 10 anos de existência na economia norte rio-grandense.

A partir disso, analisaremos há quanto tempo a empresa está inserida no cenário internacional, observando a figura 25. 


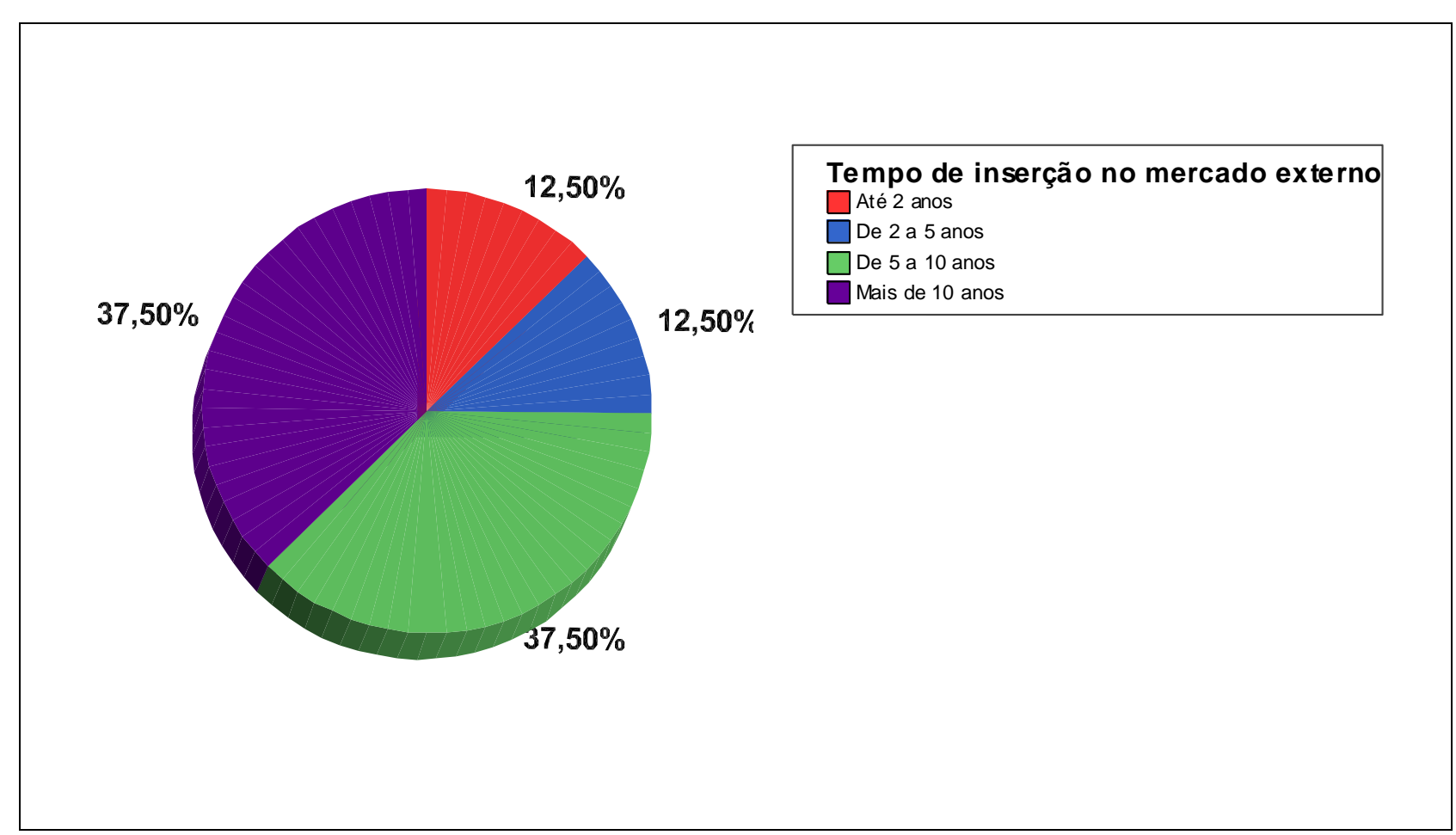

Figura 25: Tempo de Inserção no Mercado Externo.

Fonte: Pesquisa de Opinião, 2009. Elaboração: a autora.

De acordo com a figura 25, é possível observar que o tempo que as empresas estão inseridas no mercado externo é variado. Porém, mais de $70 \%$ atuam no mercado internacional há mais de 5 anos, $12,50 \%$ atuam no mercado com menos de 2 anos, e $12.5 \%$ de dois a cinco anos.

Isso mostra que as empresas do RN que exportam são ainda relativamente novas, isso pode ser explicado pelo fato do mercado ser muito instável, principalmente o internacional, que depende de muitas outras variáveis econômico-sociais em relação ao mercado interno.

O que pode ser explicado pela tabela 8 , que analisa o número de empresas que exportam ao longo dos últimos anos, quando o número de empresas exportadoras do Estado variou bastante.

A figura 26 refere-se a programa de incentivo às exportações. 


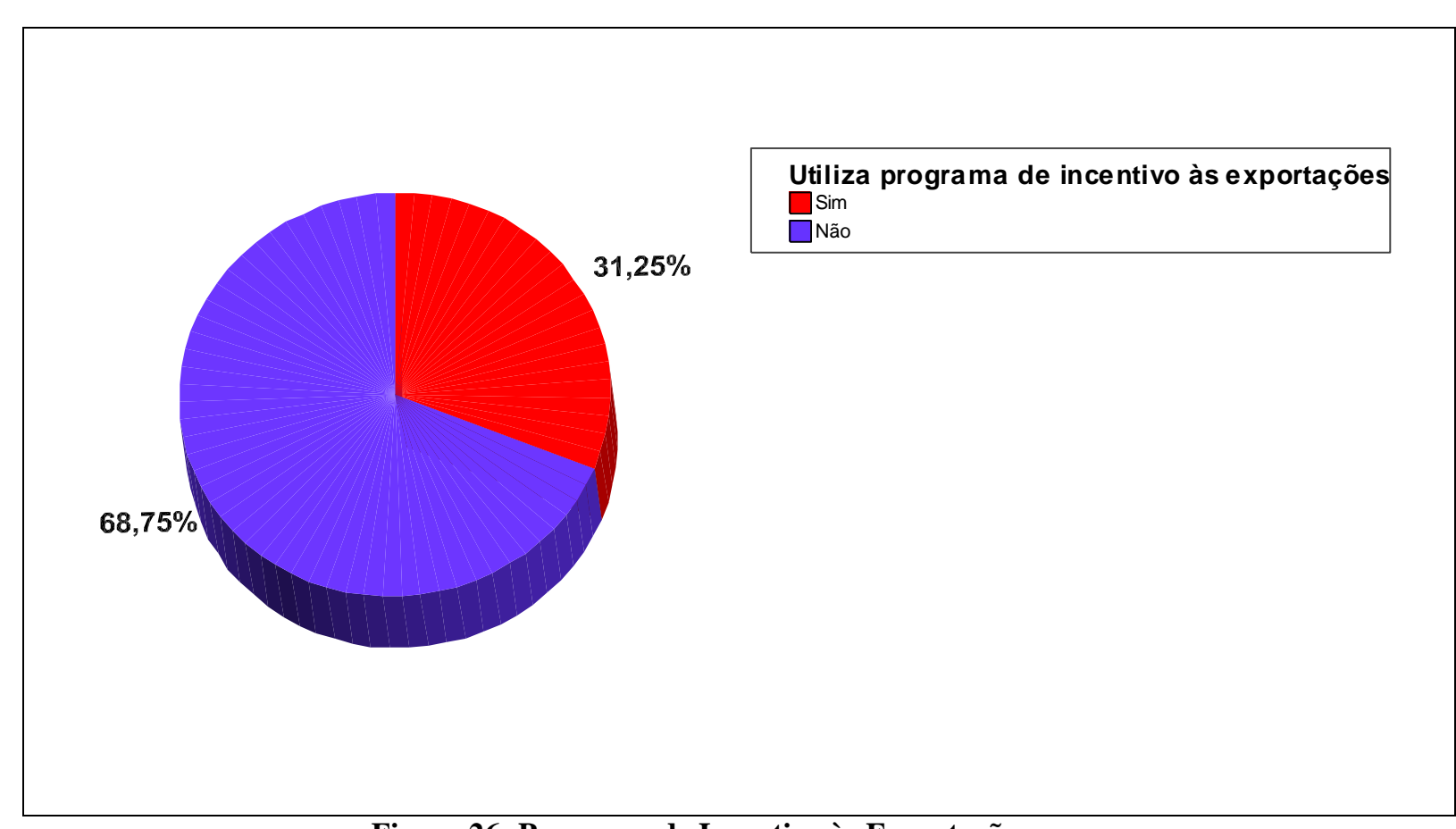

Figura 26: Programa de Incentivo às Exportações.

Fonte: Pesquisa de Opinião, 2009. Elaboração: a autora.

É possível observar na figura 26, que se faz referência a utilização de programa de incentivo às exportações no Estado do Rio Grande do Norte. Segundo a pesquisa realizada para o presente trabalho, 68,75\% não utilizam nenhum programa de incentivo às exportações, e apenas $31,25 \%$ utilizam ou já utilizaram algum programa de incentivo.

Isso indica que o governo não cria programas que realmente desperte a atenção de empresários para as exportações. Por isso, o governo deve criar políticas de exportações mais atrativas para incentivar a economia internacional. Com a figura 27 será possível analisar melhor o modo de inserção no mercado externo. 


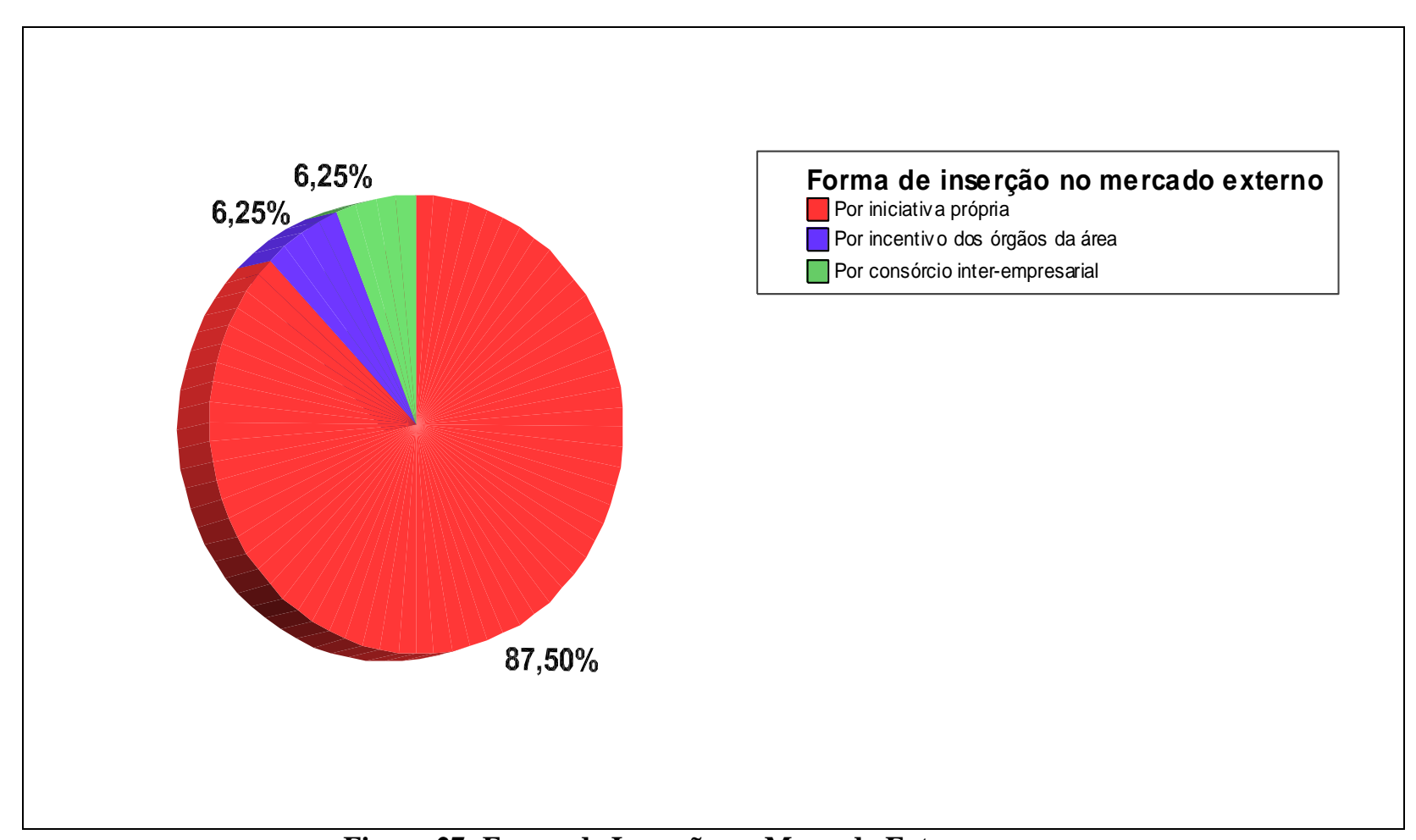

Figura 27: Forma de Inserção no Mercado Externo.

Fonte: Pesquisa de Opinião, 2009. Elaboração: a autora.

A figura 27 nos permite analisar a forma como as empresas exportadoras do RN se inseriram no mercado internacional. Segundo a figura, $87,50 \%$ das empresas exportadoras se inseriram no mercado por iniciativa própria, $6,25 \%$ por incentivo dos órgãos de fomento da área ou segmento de atuação, e outros $6,25 \%$ se inseriram através de consórcios interempresariais.

Essa figura prova que mesmo o Governo contendo vários programas de incentivo às exportações, e vários órgãos institucionais que apóiam esses programas, eles não trazem retorno significativo para os empresários, visto que a maioria das empresas entrevistadas se inseriu por iniciativa própria.

A figura 28 revela o que os empresários acham acerca do fator que interfere no comportamento dos consumidores dos produtos/serviços que empresa vende ou oferta. 


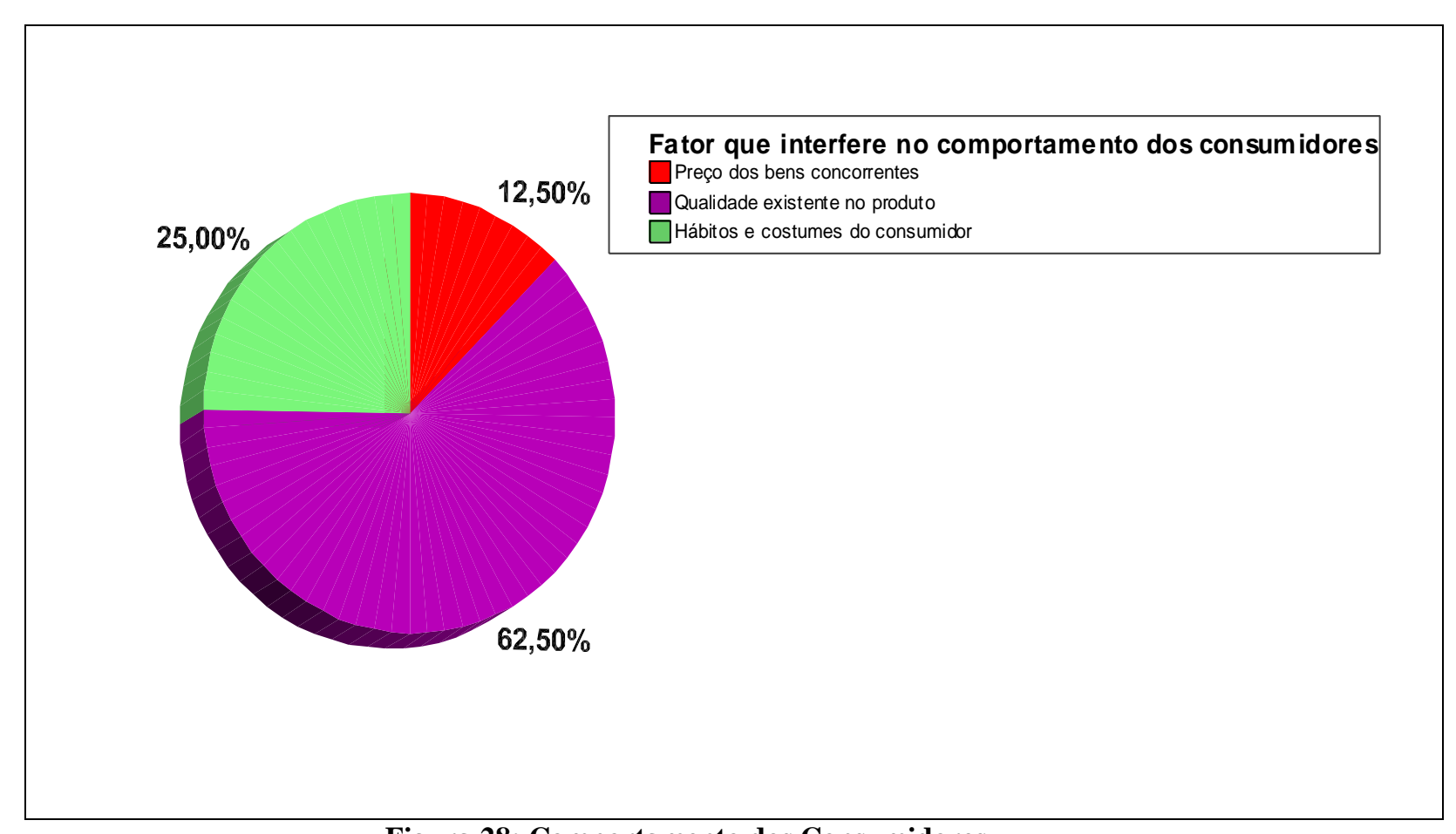

Figura 28: Comportamento dos Consumidores.

Fonte: Pesquisa de Opinião, 2009. Elaboração: a autora.

A figura 28 revela o que o principal fator que interfere no comportamento dos consumidores dos produtos da empresa. Para a maioria dos entrevistados, com 62,50\% da amostra, o que mais interfere na hora da preferência dos consumidores pelos produtos da empresa é a qualidade existente nos produtos.

Para 25\% dos empresários, o fator que mais afeta são os hábitos e costumes do consumidor; e para $12,50 \%$ acharam como fator principal o preço competitivos de seus produtos em relação aos concorrentes.

Nenhum empresário citou como fator competitivo para a escolha dos produtos, a marca da empresa, que é um fator de extrema importância para a competitividade dos produtos no mercado. A figura 29 contém a situação econômica da empresa, a fim de analisar qual o cenário interfere mais na empresa. 


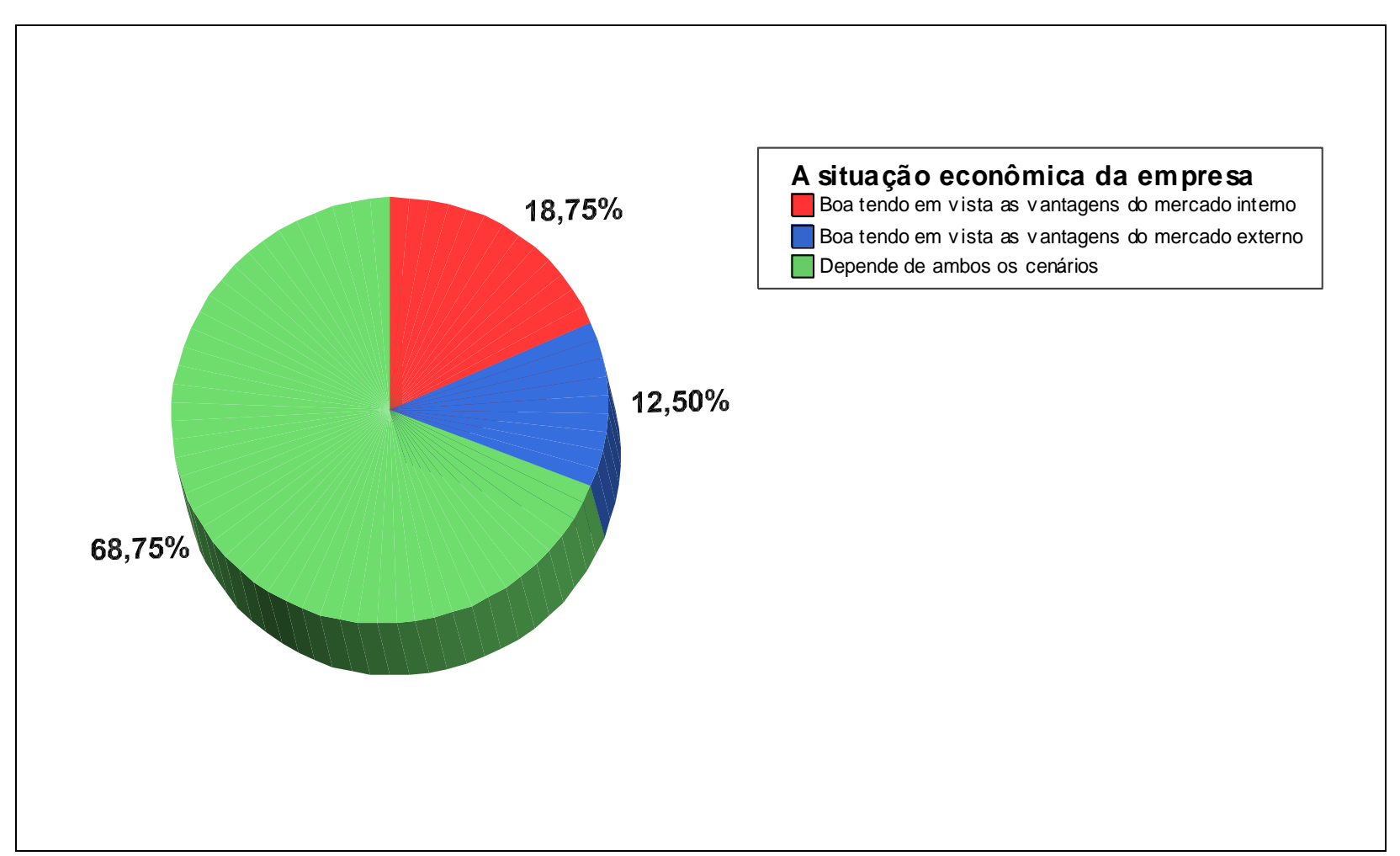

Figura 29: Situação Econômica da Empresa.

Fonte: Pesquisa de Opinião, 2009. Elaboração: a autora.

Como se pode observar na figura 29, 18,75\% dos empresários consideram a atual situação econômica da empresa boa tendo em vista as vantagens do mercado interno; já 12,50\%, consideram como ao tendo em vista as vantagens do mercado externo. E 68,75\% das empresas entrevistadas dependem de ambos os cenários na atual conjuntura econômica.

Pode-se perceber que o mercado norte-rio-grandense não está sofrendo com a atual crise mundial, visto que a maioria das empresas depende do mercado externo para permanecerem no cenário comercial, e estão conseguindo contornar bem os problemas decorrentes dessa crise.

Isso mostra o preparo das empresas do Estado, pois se assim não o fosse, os empresários estariam mais interessados em vender para o mercado nacional, pois está mais estável no momento atual, do que o mercado externo que passa por variações, principalmente no dólar, que é a principal moeda de comercialização internacional, e os EUA o maior comprador dos produtos do RN. A figura 30 mostra a demanda e oferta pelos produtos do Estado. 


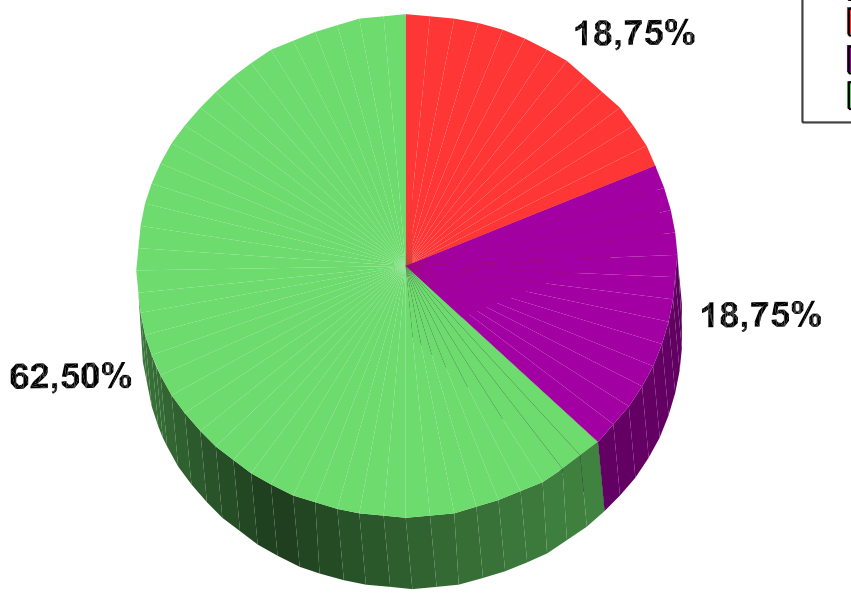

A empresa passa por situação onde

Ocorre excesso de demanda

Ocorre excesso de of erta

Equilíbrio entre of erta e demanda

Figura 30: Situação de Demanda/Oferta.

Fonte: Pesquisa de Opinião, 2009. Elaboração: a autora.

Com a figura 30, é possível analisar melhor a real situação econômica da empresa. De acordo com a figura, $18,75 \%$ das empresas passam por uma situação onde ocorre excesso de demanda, ou seja, a quantidade de produtos que está sendo procurada é meio que os produtos que estão sendo ofertados.

Outros $18,75 \%$ dos entrevistados, afirmam que a empresa passa por uma situação onde ocorre excesso de oferta, ou seja, há muito produto e pouca procura pelos produtos que estas empresas comercializam.

Mas, para a maioria das empresas exportadoras pesquisadas, com 62,50\% da amostra mantém uma situação de equilíbrio entre oferta e demanda, mostrando mais uma vez que as empresas do RN são bem estruturadas e estão bem preparadas para as instabilidades do mercado.

A figura 31, diz respeito à participação das empresas entrevistadas na balança comercial do Rio Grande do Norte. 


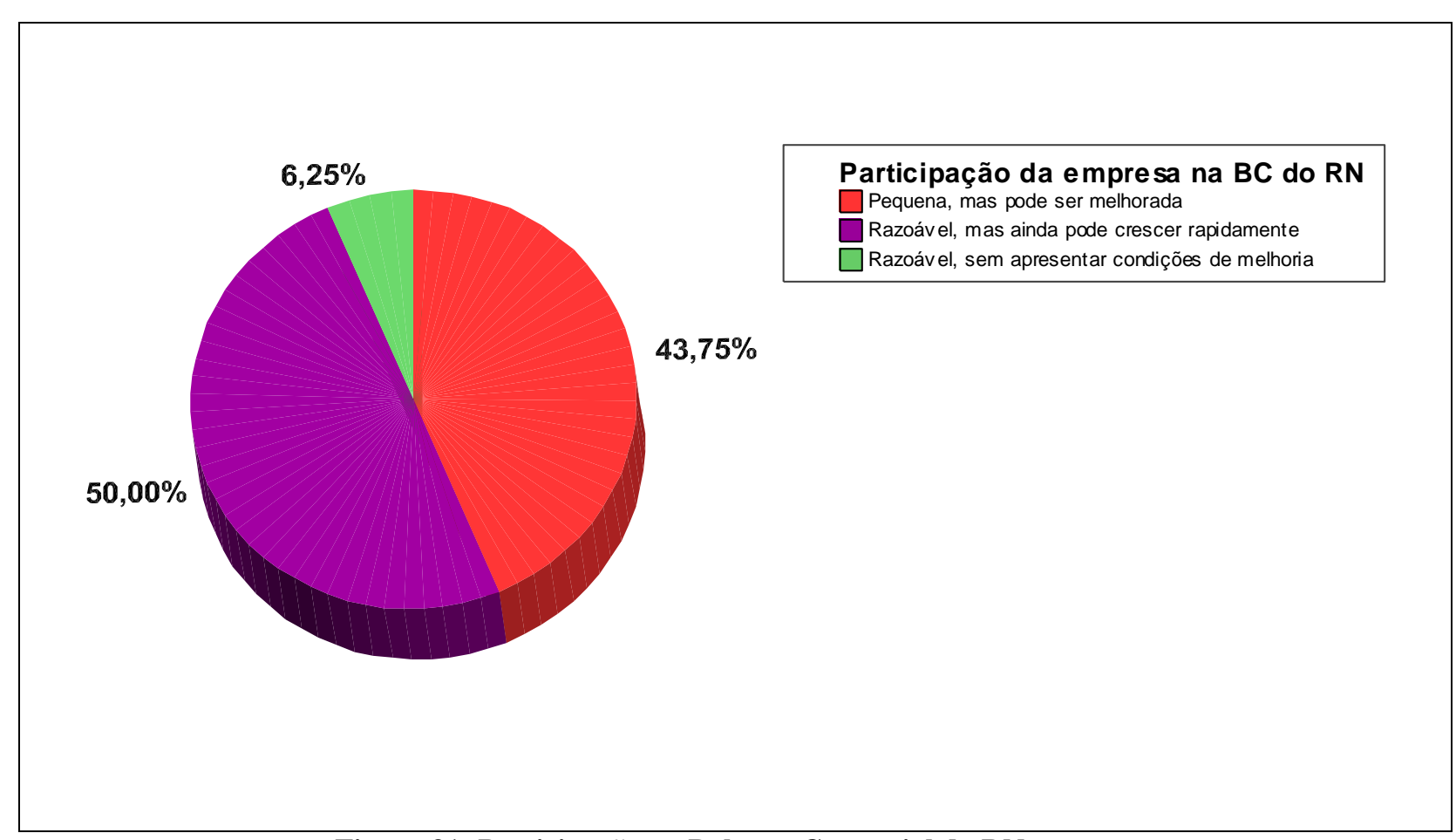

Figura 31: Participação na Balança Comercial do RN.

Fonte: Pesquisa de Opinião, 2009. Elaboração: a autora.

É possível observar na figura 31 , na concepção de $50 \%$ dos empresários entrevistados consideram como razoável, mas que ainda pode crescer rapidamente, a participação da empresa na balança comercial do RN.

Já para 43,75\% das empresas pesquisadas, consideram a participação na balança comercial como sendo pequena, mas que pode ser melhorada. E apenas $6,25 \%$, acreditam que a participação na balança comercial e razoável, mas sem apresentar condições de melhoria nos próximos meses. 


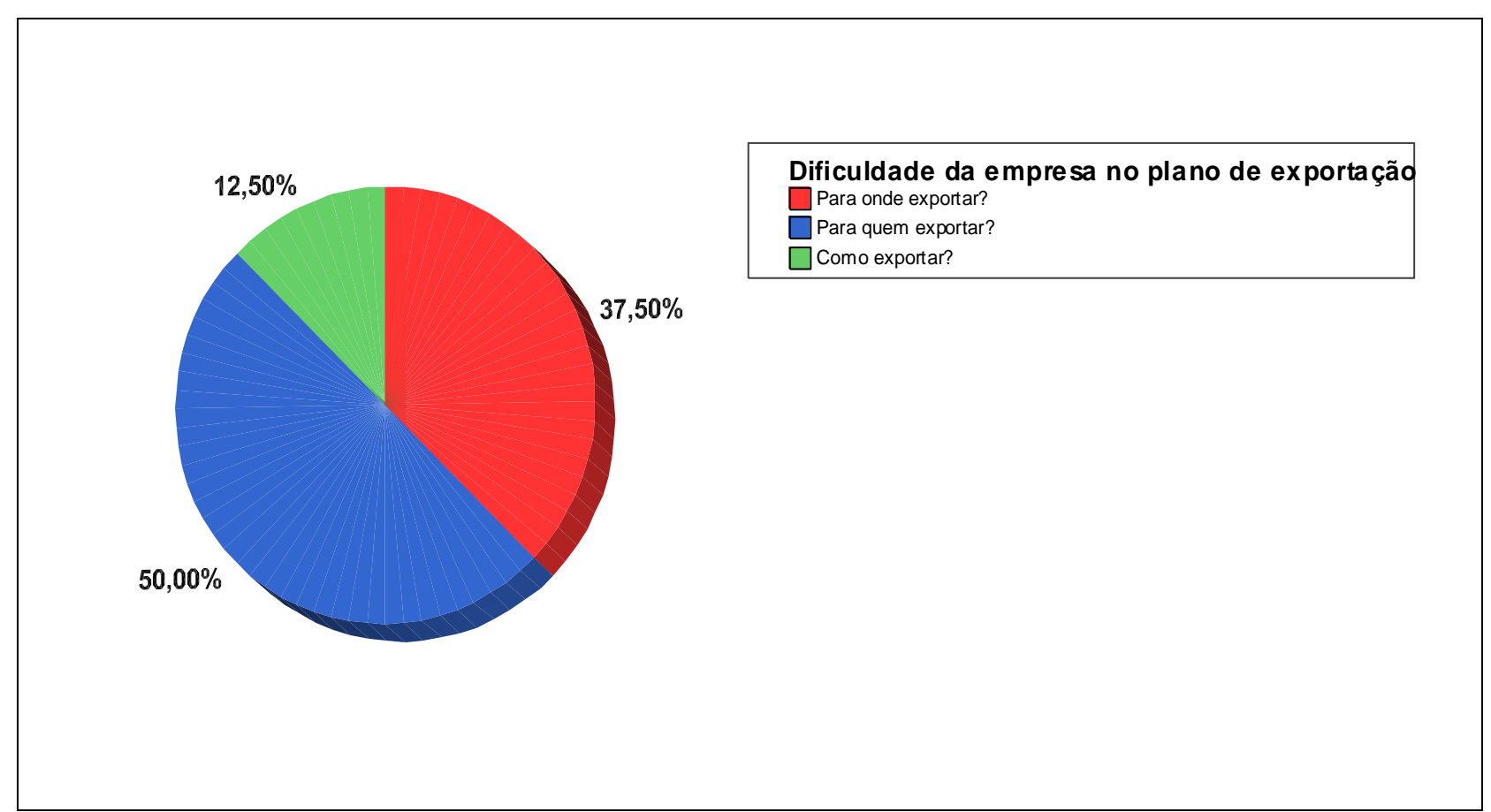

Figura 32: Dificuldade Encontrada no Plano de Internacionalização. Fonte: Pesquisa de Opinião, 2009. Elaboração: a autora.

A figura 32, trata da maior dificuldade encontrada pela empresa em relação ao seu plano de internacionalização. Segundo a figura 32, 50\% das empresas acham que a maior dificuldade encontrada é saber para quem exportar. O que mostra que a grande dificuldade é localizar o potencial comprador de seus produtos - a empresa ou o importador.

Já 37,50\% dos entrevistados, afirma que a maior dificuldade é para onde exportar, ou seja, para que país. A situação destes já é mais difícil em relação ao apresentado anteriormente, pois enquanto aqueles não sabiam para quem, estes não sabem nem para onde, isso quer dizer que eles não sabem do importador que possa comprar seus produtos, nem onde eles se localizam.

Para 12,50\% das empresas questionadas não sabem como exportar, com isso pode-se afirmar que estas utilizam de alguma consultoria em comércio internacional, ou que terceirizam os serviços de exportação.

Vale ressaltar que nenhum empresário citou como principal dificuldade no plano de internacionalização o que exportar, mostrando que estes sabem o mercado onde se inserir e que produtos são competitivos no cenário internacional; e o por que de exportar, mostrando que os empresário sabem por que estão no mercado, e o que a exportação pode trazer de benefício para as empresas exportadoras, assim como para a economia local.

A figura 33 apresenta a principal dificuldade encontrada ao exportar. 


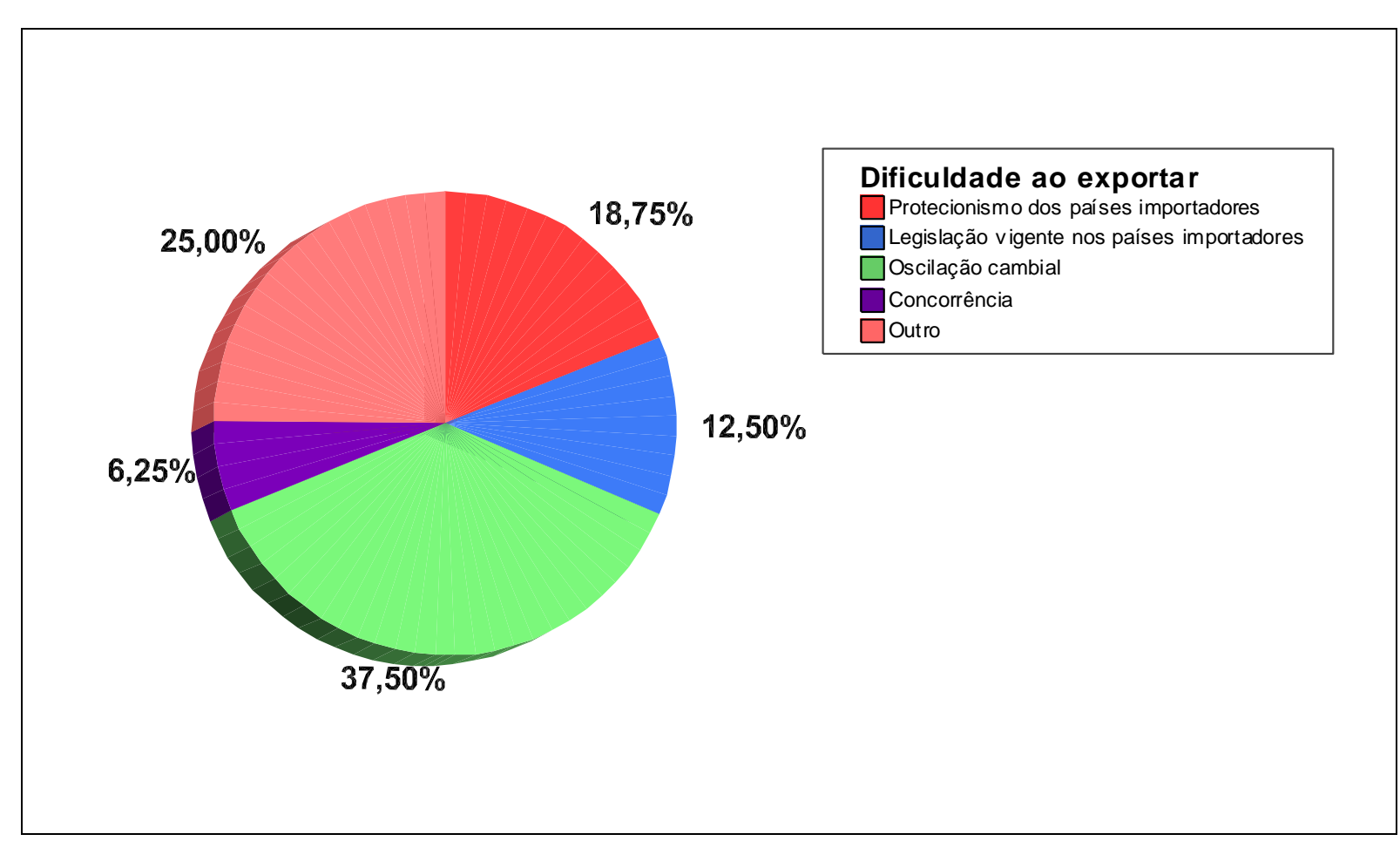

Figura 33: Dificuldade Encontrada ao Exportar.

Fonte: Pesquisa de Opinião, 2009. Elaboração: a autora.

Como pode-se observar na figura 33, as respostas dos entrevistados foram bem variadas em relação a principal dificuldade ao exportar, o que mostra que não há um problema específico que dificulte as exportações.

Para 37,50\% dos entrevistados, a principal dificuldade encontrada ao exportar é a oscilação cambial, a grande vilã do comércio internacional; para 18,75 \% das empresas pesquisadas, a maior dificuldade é o protecionismo por parte dos países importadores; já para $12,50 \%$ é o cumprimento da legislação vigente nos países importadores; e apenas 6,25\% acharam que a concorrência é o fator que dificulta as exportações. Já para $25 \%$ das empresas entrevistadas, consideraram outros fatores diversos que dificultam as exportações do Rio Grande do Norte.

A figura 34, mostra como são realizadas as exportações das empresas do Estado. 


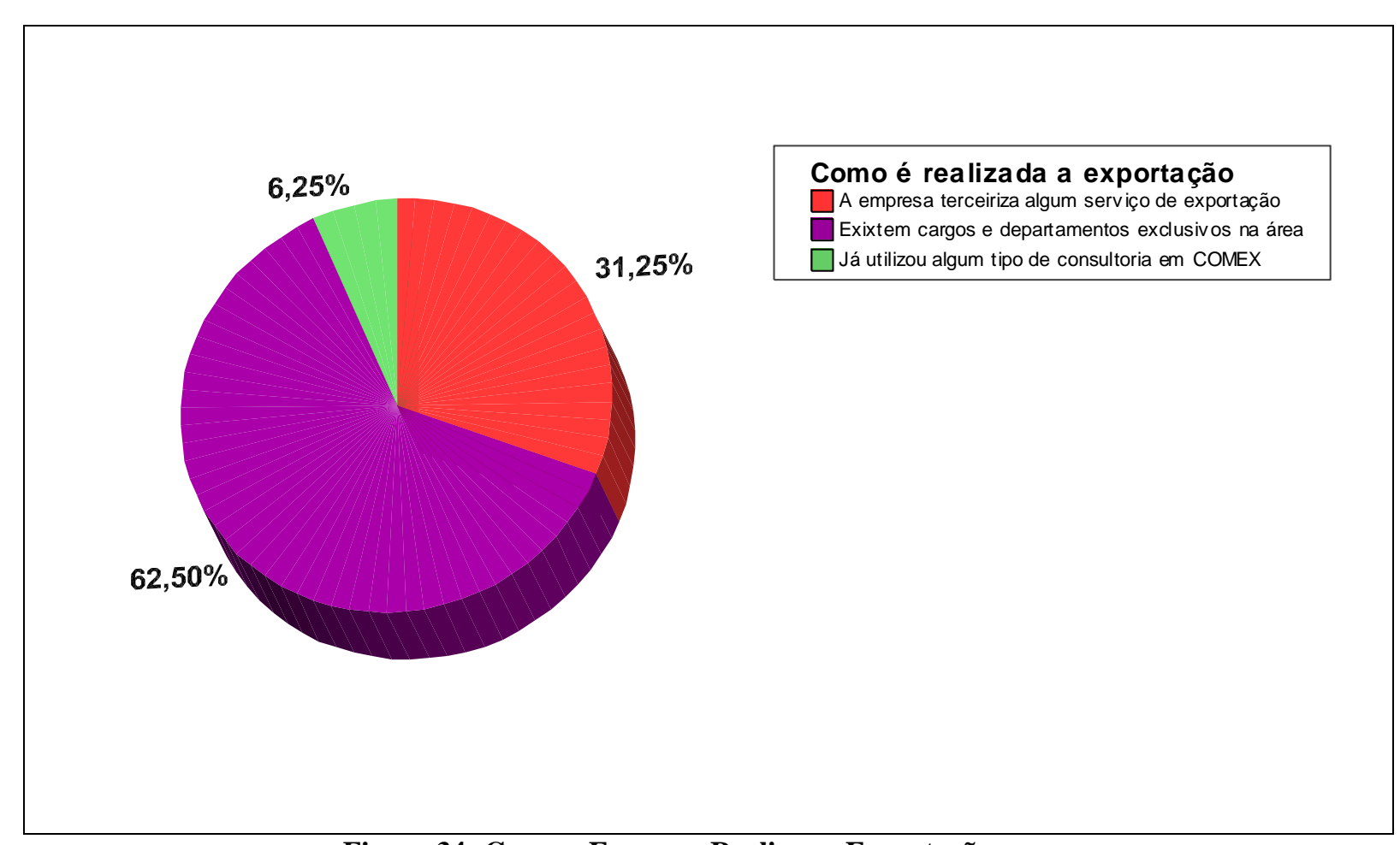

Figura 34: Como a Empresa Realiza as Exportações.

Fonte: Pesquisa de Opinião, 2009. Elaboração: a autora.

$\mathrm{Na}$ figura 34, como pode-se observar, 62,50\% das empresas exportadoras pesquisadas possuem cargos e departamentos exclusivos na área. Já 31,25\% das empresas, terceirizam algum serviço de consultoria na área exportadora, seja para o desembaraço das mercadorias, ou preenchimentos de documentos, análise de mercado. E 6,25\% das entrevistadas, já utilizaram algum tipo de consultoria em comércio exterior.

Esse cenário mostra que a maioria das empresas do RN, já estão consolidadas no mercado externo e que exportam seus produtos com certa frequiência, visto a eficiência e custos mais baixos de manter departamentos exclusivos na área exportadora na empresa ao invés de freqüentemente contratar os serviços de acessória e consultoria.

Entendido esse quadro, o presente trabalho tem por objetivo entender esse cenário das empresas e analisar a colocação dos alunos do Curso de Comércio Exterior do IFRN, nas empresas exportadoras do Estado. As figuras 35, 36 e 37, ajudará a entender este questionamento. 


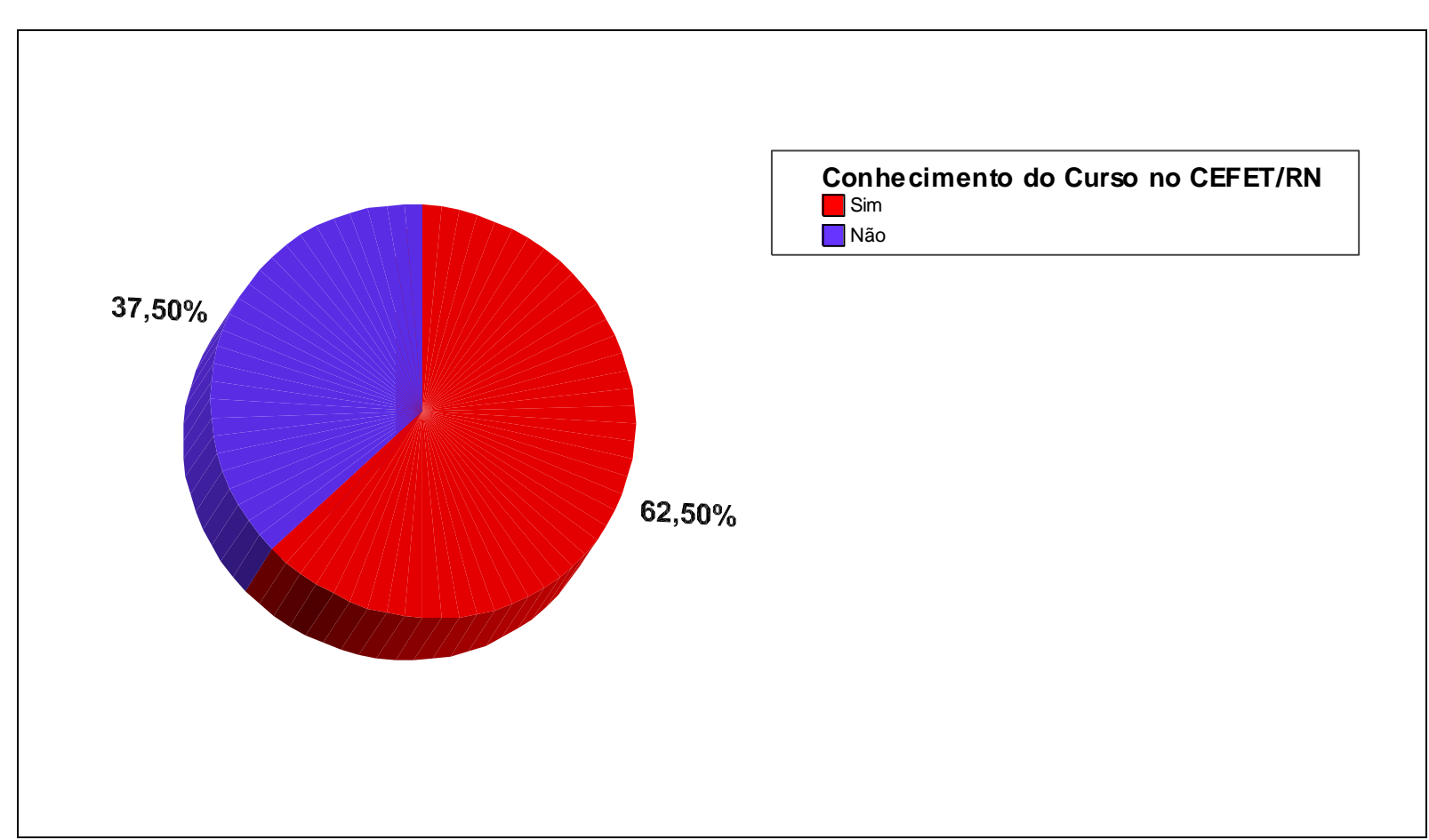

Figura 35: Conhecimento do Curso de COMEX do IFRN.

Fonte: Pesquisa de Opinião, 2009. Elaboração: a autora.

De acordo com o que se pode analisar na figura 35, foi questionado as empresas entrevistadas, se estas possuíam conhecimento do Curso Superior de Tecnologia em Comércio Exterior que o IFRN oferece.

Para 62,50\% dos entrevistados, a resposta foi positiva, ou seja, tinham conhecimento sobre a existência do curso na Instituição. Mas para 37,50\%, nunca ouviram falar da existência do curso de COMEX, um número relativamente alto dada a importância do curso para as empresas exportadoras do $\mathrm{RN}$, como também para a inserção dos alunos no mercado de trabalho.

Dessa forma, o desconhecimento do curso pelos empresários faz com que dificulte a colocação dos aluno do curso no mercado, assim como a dificuldade de encontrar estágio para os alunos na área, o que é de extrema importância para enriquecer o conhecimento dos alunos que aliam a teoria à prática. 


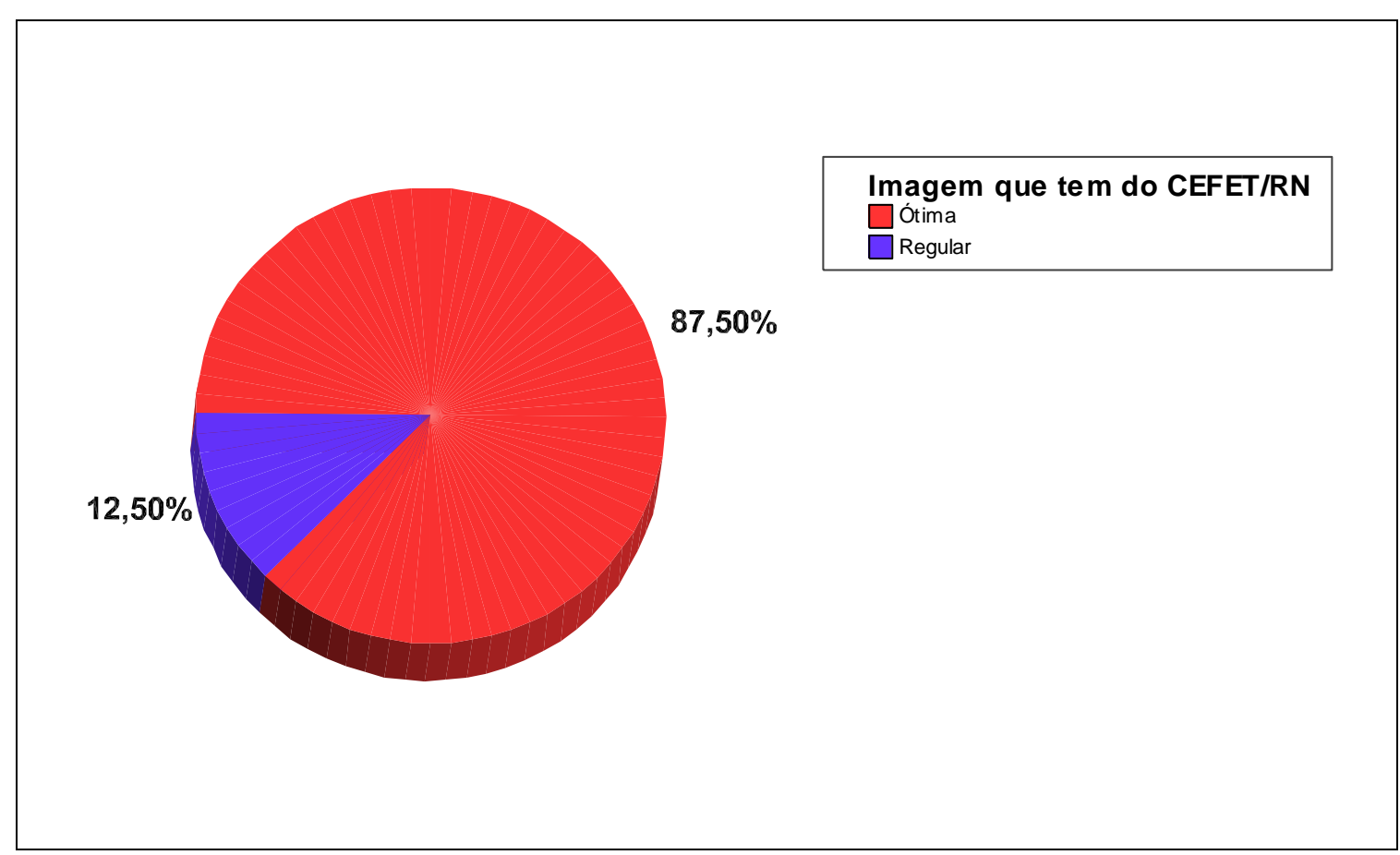

Figura 36: Imagem que a Empresa tem do IFRN.

Fonte: Pesquisa de Opinião, 2009. Elaboração: a autora.

A figura 36, faz referência a imagem que os empresários têm do IFRN (antigo CEFET/RN). Para 87,50\% dos entrevistados consideram a Instituição de ensino como ótima. Apenas para 12,50\%, O IFRN é visto como regular.

Isso mostra a grande confiança que a instituição tem por parte dos empresários, como um estabelecimento idôneo, com ensino qualificado. $\mathrm{O}$ que facilita a inserção dos alunos no mercado de trabalho, pela boa procedência e base que os alunos obtiveram no ensino.

Mas pouco adianta se a instituição tiver prestígio e não divulgar os cursos que oferece, uma vez que para a colocação dos alunos no mercado será dificultada pelo desconhecimento da existência do profissional qualificado para as deficiências das empresas do RN.

A figura 37, mostra a relação entre o aluno de Comércio Exterior e as empresas que foram entrevistadas ao longo desse trabalho. 


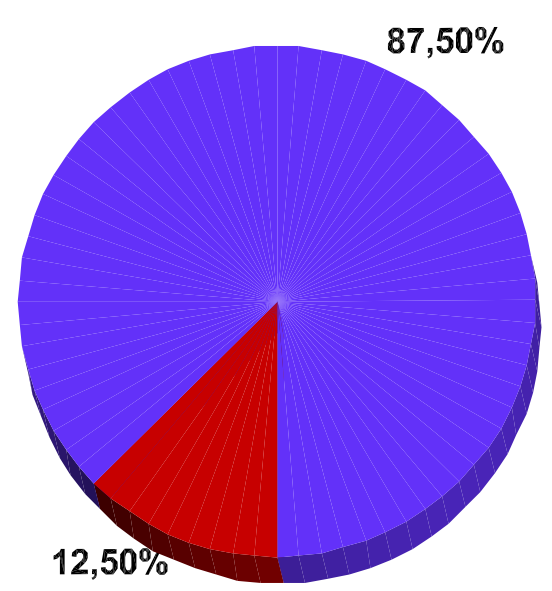

Em relação aos alunos de COMEX

Já contratou algum aluno de COMEX

$\square$ Contrataria, caso necessitasse

Figura 37: Relação da Empresa com os Alunos de COMEX.

Fonte: Pesquisa de Opinião, 2009. Elaboração: a autora.

A figura 37, visa analisar a inserção dos alunos de Comércio Exterior nas empresas exportadoras. Das empresas entrevistadas, $87,50 \%$ nunca contratou um alunos de comércio exterior, mas contrataria casso necessitasse. Apenas 12,50\% das empresas já contrataram algum aluno de Comércio Exterior.

Esse quadro mostra a baixa colocação dos alunos de Comércio Exterior mo mercado de trabalho, principalmente nas empresas exportadoras do Rio Grande de Norte. Isso pode ser explicado em partes pelo desconhecimento da existência do curso, como também pela falta de parcerias com as grandes corporações exportadoras da região.

Assim sendo, esse cenário acaba desvalorizando o curso de Comércio Exterior do IFRN, uma vez que, não há uma rápida colocação no mercado das empresas que exportam na região. Sendo assim, os alunos do curso são desestimulados ao longo da vida acadêmica, quando se deparam com a dificuldade de encontrar estágios na área.

Para modificar essa situação, a instituição deverá procurar parcerias com essa as grandes empresas do Estado, à fim de promover a inserção dos alunos na realidade exportadora da região, como também promover o nome da instituição e do Curso Superior de Tecnologia em Comércio Exterior.

Os próximos figuras visam identificar a carências das empresas que foram entrevistadas, e analisar a necessidade de consultoria dessas empresas. 


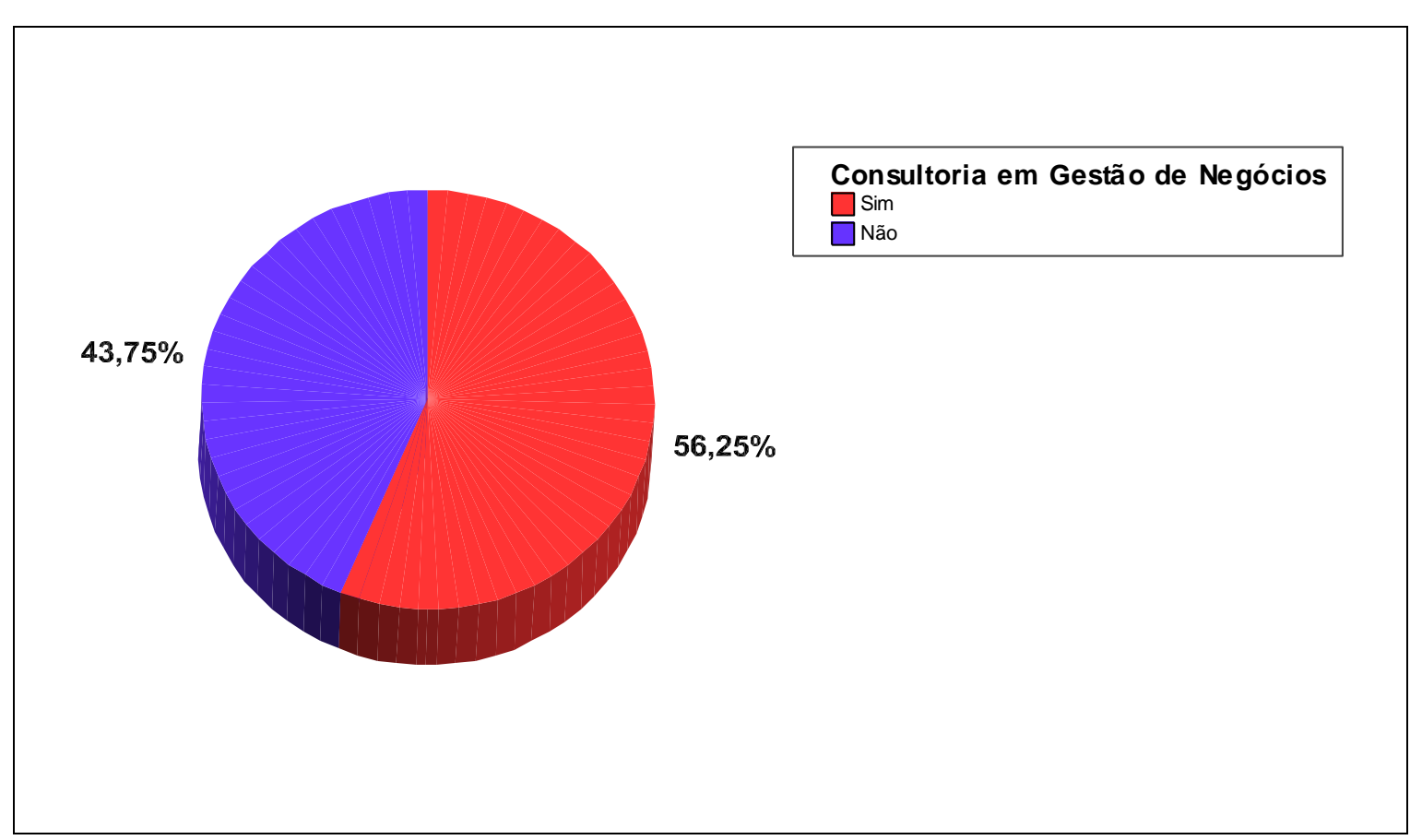

Figura 38: Consultoria em Gestão de Negócios.

Fonte: Pesquisa de Opinião, 2009. Elaboração: a autora.

A figura 38, apresenta o interesse de consultoria em gestão de negócios por parte dos empresários entrevistados na pesquisa. Como pode-se ver, 56,25\% dos empresários sentem necessidade de consultoria nessa área. E 43,75\%, não tem interesse.

A área de gestão de negócios visa dar suporte ao empresário, no que tange a forma de gerir, comandar, administrar o negócio. Na figura 38 pode-se analisar o alto interesse por esse curso, o que revela um pouco a insegurança dos empresários no que diz respeito a administração da empresa entrevistada.

A figura 39, refere-se à consultoria em gestão de pessoas. 


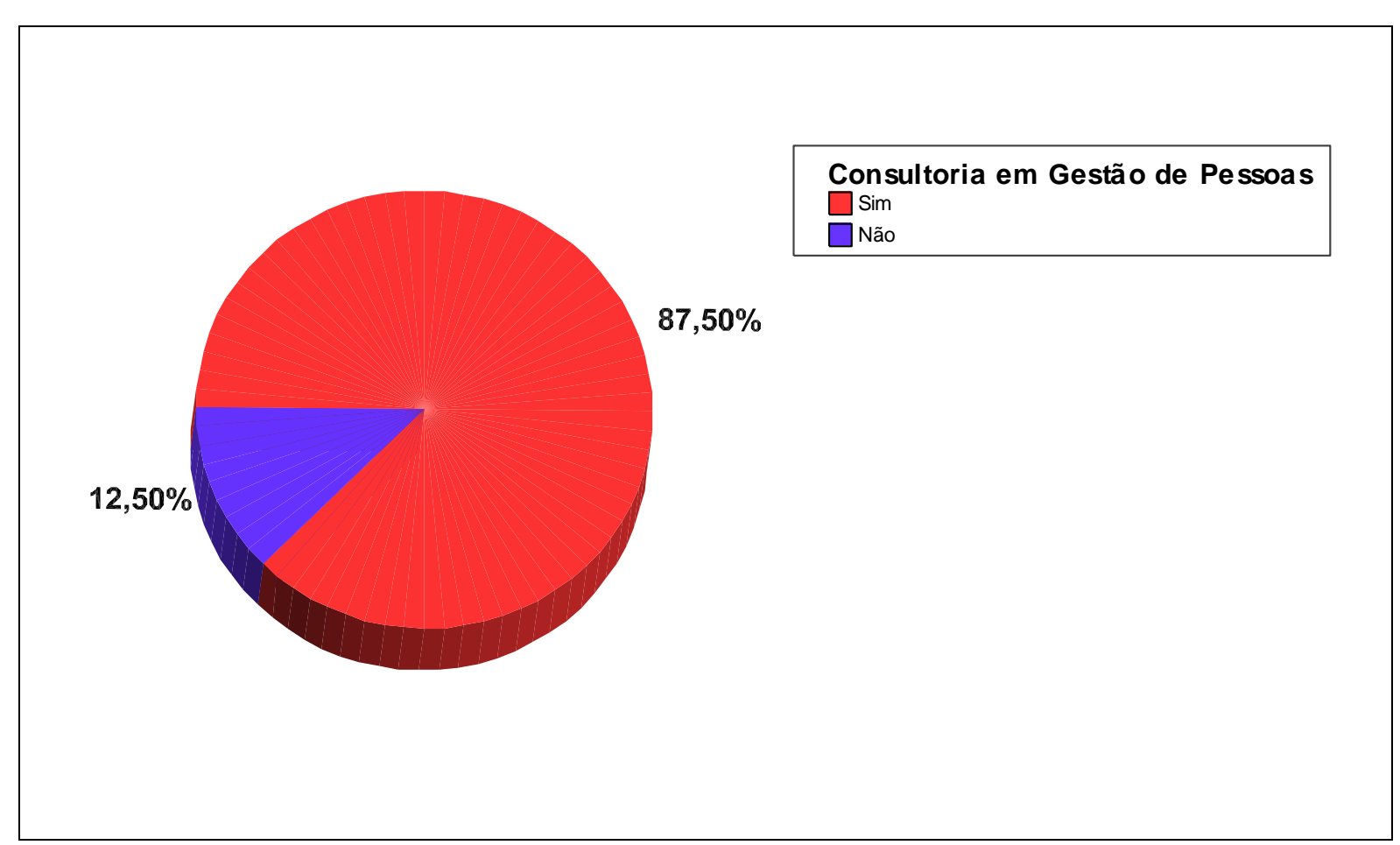

Figura 39: Consultoria em Gestão de Pessoas.

Fonte: Pesquisa de Opinião, 2009. Elaboração: a autora.

A figura 39, faz alusão a consultoria em gestão de pessoas. Segundo o figura $2687,50 \%$ dos entrevistados, tem interessem em consultoria em gestão de pessoas. Os outros $12,50 \%$ não acham necessário esse tipo de consultoria para o seu empreendimento.

Os cursos de gestão de pessoas são de extrema importância para as empresas, uma vez que permite ao empresário conhecer e identificar as potencialidades dos profissionais das corporações. A grande demanda por esse tipo de consultoria nos permite analisar a preocupação dos empresários com seus funcionários, uma vez que, a produtividade das empresas depende em grande parte dos funcionários. 


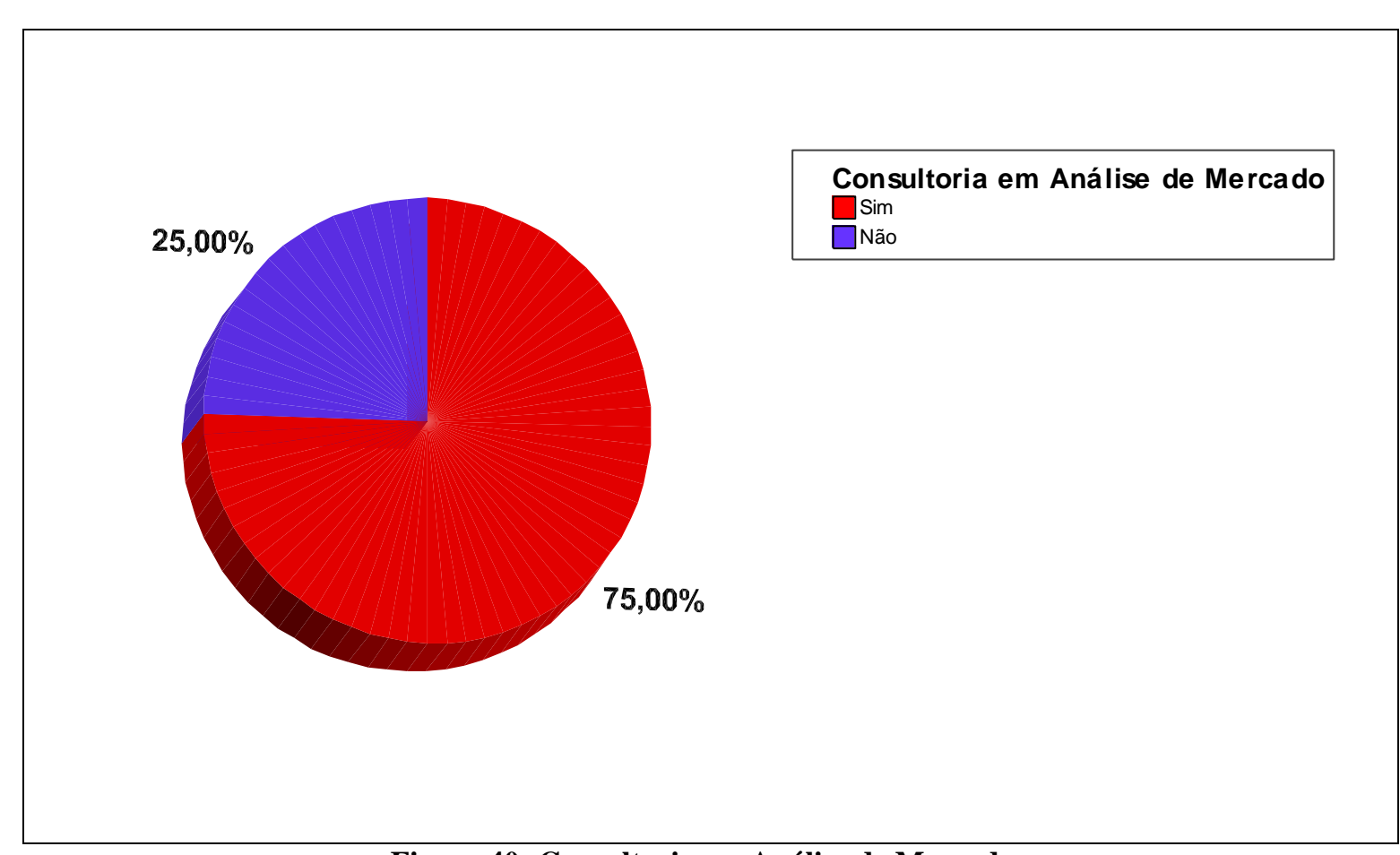

Figura 40: Consultoria em Análise de Mercado.

Fonte: Pesquisa de Opinião, 2009. Elaboração: a autora.

A figura 40, revela a necessidade de consultoria em análise de mercado, seja no âmbito nacional ou internacional. De acordo com o figura, $75 \%$ das empresas entrevistadas têm interesse por curso de análise de mercado, e apenas $25 \%$ das empresas não tem interesse.

Diante do que foi exposto é possível analisar que há uma demanda muito grande por cursos de análise de mercado, isso porque uma das principais dificuldades ao exportar é definir o potencial cliente, como também os países possíveis compradores dos produtos que as empresas oferecem.

Além disso, a análise de mercado permite visualizar as carências por determinados serviços e produtos, e analisando a demanda e o comportamento dos consumidores, que influenciam diretamente na escolha dos produtos e/ou serviços que as empresas oferecem ou que pretendem oferecer. 


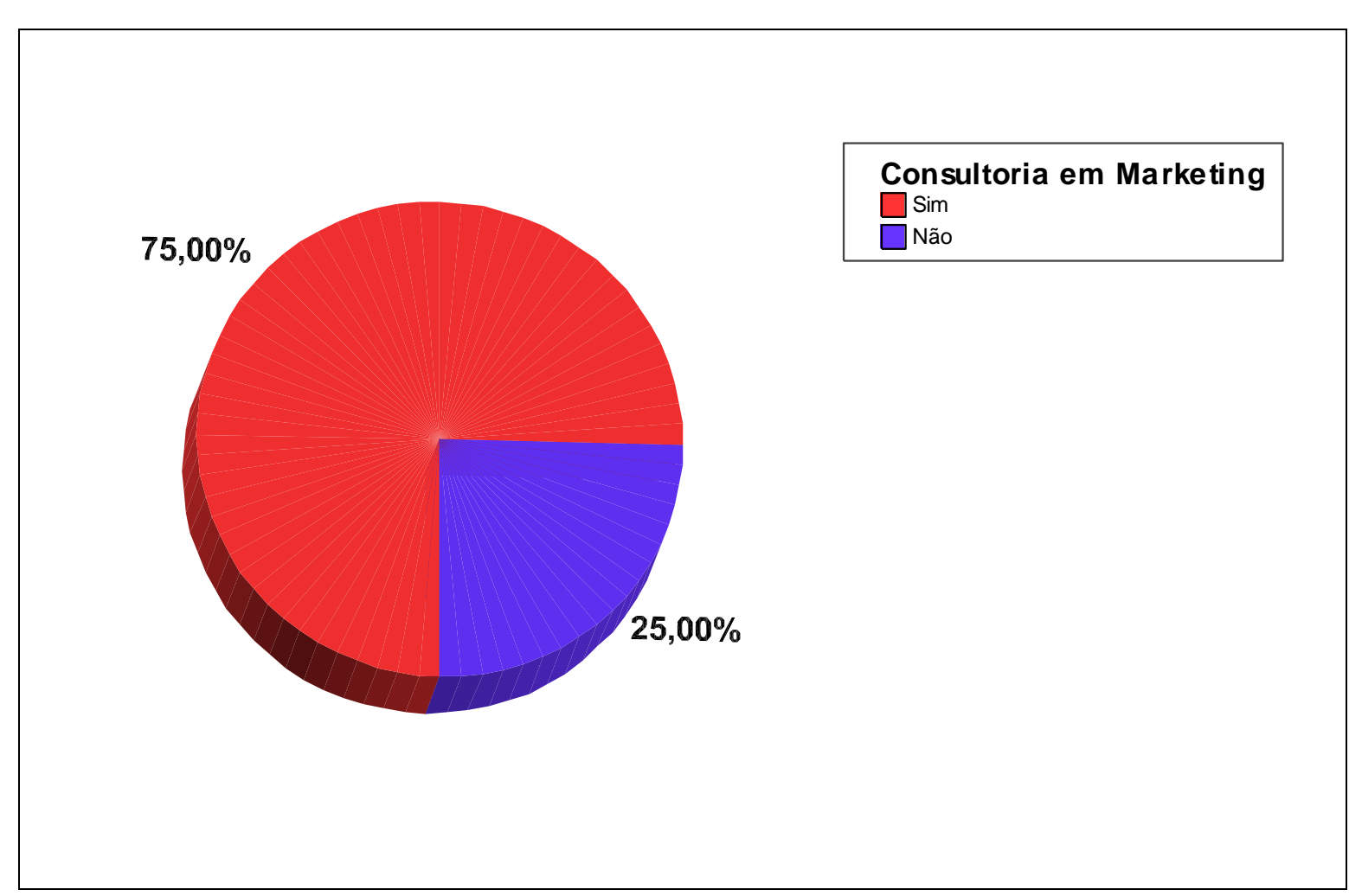

Figura 41: Consultoria em Marketing.

Fonte: Pesquisa de Opinião, 2009. Elaboração: a autora.

Já a figura 41, refere-se à necessidade de consultoria em marketing. Para $75 \%$ dos entrevistados, há interesses por essa consultoria. Já $25 \%$ dos entrevistados não estão interessados nesse tipo de consultoria.

Percebe-se que a maioria dos empresários sente necessidade em melhorar a promoção dos seus produtos, seja no mercado interno ou no mercado externo. Ao longo da pesquisa foi possível observar que grande parte das empresas exportadoras não possuía setor específico de marketing. Isso porque, é muito difícil promover o produto no mercado externo, uma vez que esse tipo de trabalho demanda muito esforço, e altos custos por parte das empresas, já que para isso, é necessário conhecer toda a cultura e costumes do país a que se destina tal evento.

Por isso, a demanda para esse tipo de consultoria é demasiada, logo que a carência de marketing nesse setor é escassa, e muitas vezes inexistente, pois na maioria das vezes os exportadores costumam vender para os mesmos compradores. 


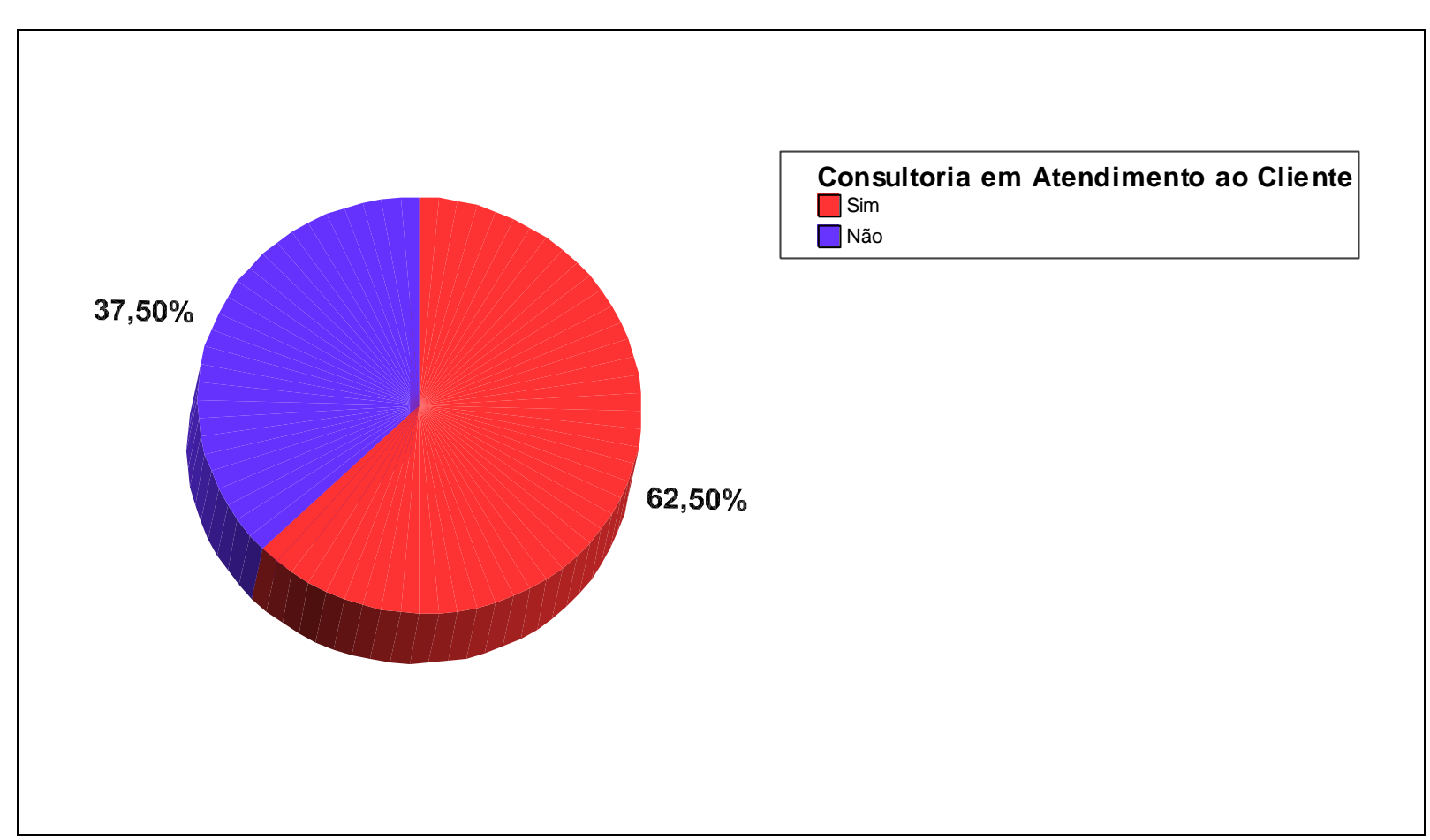

Figura 42: Consultoria em Atendimento ao Cliente.
Fonte: Pesquisa de Opinião, 2009. Elaboração: a autora.

A figura 42, permite analisar a necessidade dos entrevistados em consultoria de atendimento ao cliente. Segundo o figura 26, 87,50\% das empresas entrevistadas gostaria de receber cursos referentes a atendimentos dos clientes. Apenas 12,50\%, não acham necessária a consultoria nessa área, por argumentarem que por não lidar diretamente com clientes, não necessitam desse suporte, porém consideram essa consultoria de extrema importância para as empresas que trabalham diretamente com clientes.

Lidar com pessoas é uma tarefa extremamente difícil, que exige paciência e bom senso, uma vez que, as pessoas estão sujeitas a mudanças de humor, e os profissionais que trabalham diretamente com pessoas precisam estar preparados para todos os tipos de situação.

Por isso, a procura por estes tipos de cursos são cada vez maiores, o que revela a grande preocupação dos empresários com os serviços oferecidos e principalmente com o atendimento ao cliente, que nos últimos anos, vem se tornando um fator decisivo na fidelização de clientes.

A figura 43, permite analisar como os entrevistados vêem a administração da empresa que trabalham. 


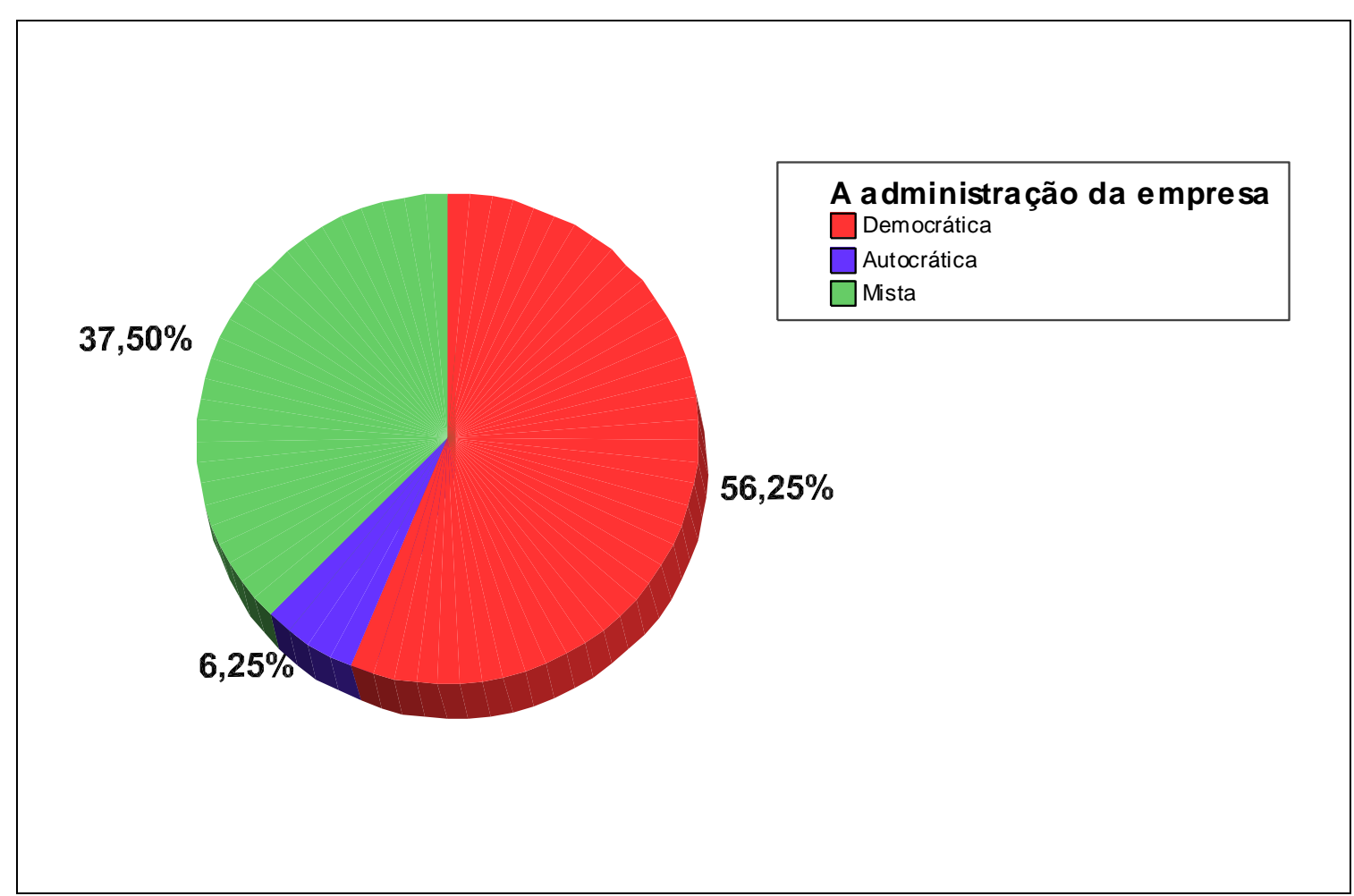

Figura 43: Administração da Empresa.

Fonte: Pesquisa de Opinião, 2009. Elaboração: a autora.

A figura 43, procura apresentar a administração das empresas exportadoras do RN. Como é possível observar, $56,25 \%$ dos entrevistados consideram a administração da sua empresa como democrática, ou seja, as decisões são tomadas em conjunto com todos da empresa. É um tipo de administração que visa inserir todos os funcionários nas decisões, procurando incentivar todos a promover a empresa.

Para 37,50\% dos entrevistados, a administração da empresa é mista, ou seja, as decisões são tomadas após reunião com os funcionários, e os diretores e presidentes decidem pela melhor escolha a ser tomada.

Apenas 6,25\% das empresas pesquisadas entendem que a administração da empresa é autocrática, que consiste na decisão ser tomada pelo representante da empresa, sem consulta aos demais funcionários. É um tipo de administração mais rígida e conservadora. O modelo de gestão da empresa é fundamental para delinear o crescimento do empreendimento, pois os funcionários podem se sentir estimulados ou não com o tipo de gestão. Por isso, o modelo de gestão deve ser decidido de acordo com o perfil dos funcionários, uma vez que estes são imprescindíveis para o crescimento e desenvolvimento da organização.

\section{CORRELAÇÕES}

Estatisticamente, a correlação indica a força de direção do relacionamento linear entre duas variáveis aleatórias, ou seja, o quanto uma variável pode influenciar em outra variável (TRIOLA, 1998).

O índice de correlações, como supracitado anteriormente, são dados pelas correlações entre as variantes, ou seja, quanto mais próximo de +1 , mais correlação haverá entre as 
variáveis, isto é, se uma variável aumentar, a outra variável relacionada tenderá estatisticamente a aumentar.

Mas se a correlação for negativa, quanto mais próxima ela estiver de -1, quer dizer que, quanto mais a variável correlacionada aumentar, a outra variável relacionada tenderá a diminuir.

É importante frizar que todas as variáveis da pesquisa, isto é, todas as perguntas do questionário, foram cruzadas com o escopo de obter as correlções. Porém, apenas as correlações apresentadas aqui foram significantes para a pesquisa. Estatisticamente falando, as correlações aqui apresentadas, estão mais próximas de +1 ou -1 , que indicam os índices mais altos de correlação.

A primeira correlação, está representada na tabela 3, que apresenta a correlação entre o modelo de Gestão da Empresa com a necessidade de Consultoria em Gestão de Negócios.

Tabela 3 - Correlação 1

\begin{tabular}{lc}
\hline \multicolumn{1}{c|}{ VARIÁVEIS } & CORRELAÇÃO \\
\hline $\begin{array}{l}\text { Modelo de Administração da Empresa } \\
\text { Necessidade de Consultoria em Gestão de Negócios }\end{array}$ \\
\hline \multicolumn{2}{c}{ Fonte: Pesquisa de Opinião, 2009. Elaboração: a autora. }
\end{tabular}

Considerando-se o Coeficiente de Correlação Linear e sua variação (MILONE, 2004), pode-se concluir que a forma de Gestão da Empresa está diretamente correlacionada com a Necessidade de Consultoria em Gestão de Negócio. Ou seja, as Empresas com Modelo Democrático de Gestão estão mais propensas a aceitar Consultorias de Gestão de Negócios.

Outrossim, as Empresas que possuem uma Gestão Mista, isto é, ora possuem um modelo de gestão participativa e ora possuem um modelo autocrático de gestão, tem uma menor probabilidade a participarem ou investirem em Cursos de Gestão de Negócios para seus empreendimentos.

A tabela 4, permite visualizar a correlação 2 , que refere-se ao tempo de inserção no mercado, com a situação econômica da empresa.

Tabela 4 - Correlação 2

\begin{tabular}{lc}
\hline \multicolumn{1}{c|}{ VARIÁVEIS } & CORRELAÇÃO \\
\hline Tempo de Inserção no Mercado Interno & 0,669 \\
Situação de Demanda/Oferta da Empresa & \\
\hline
\end{tabular}

Fonte: Pesquisa de Opinião, 2009. Elaboração: a autora. 
A tabela 4, correlaciona o tempo de inserção das Empresas no Mercado Interno, com a situação de Demanda/Oferta da empresa, isto é, se ela está passando atualmente por um situação onde ocorre excesso de demanda, situação onde ocorre excesso de oferta ou situações de equilíbrio entre oferta e demanda.

Considerando-se o Coeficiente de Correlação Linear e sua variação (MILONE, 2004), foi possível concluir que o tempo de inserção no mercado interno está diretamente correlacionado com a situação econômica equilibrada da empresa. Ou seja, as Empresas com mais tempo no mercado, que estão inseridas no figura como tendo mais de dez anos, estão mais propensas a ter situação de equilíbrio entre oferta e demanda.

Com isso, pode-se concluir também que as empresas exportadoras que possuem um tempo de atividade no mercado interno, entre dois e cinco anos, estão estatisticamente menos vulneráveis a situações de equilíbrio, variando entre situações de excesso de demanda ou excesso de oferta.

Já a tabela 5, faz referência ao tempo de atividade no mercado externo correlacionado ao comportamentos dos consumidores dos produtos/serviços da empresa.

Tabela 5 - Correlação 3

\begin{tabular}{lc}
\hline \multicolumn{1}{c|}{ VARIÁ VEIS } & CORRELAÇÃO \\
\hline Tempo de Inserção no Mercado Externo & $-0,521$ \\
Comportamento dos Consumidores & \\
\hline
\end{tabular}

Fonte: Pesquisa de Opinião, 2009. Elaboração: a autora.

De acordo com a tabela 5, a correlação significante é entre o tempo de atividade das empresas no Mercado Externo correlacionado com o fator que interfere no comportamento dos consumidores dos produtos/serviços que a empresa vende ou oferta.

Levando-se em consideração o Coeficiente de Correlação Linear e sua variação (MILONE, 2004), chegou-se a conclusão de que o tempo de inserção no Mercado Externo está inversamente correlacionado com a Motivação dos Consumidores das Empresas. Isto é, as Empresas com menos tempo no Mercado Externo têm como principal Motivação de seus Consumidores a Qualidade existente no Produto.

Igualmente, as empresas que estão a mais tempo no Mercado Externo têm como principal fator que interfere no comportamento dos Consumidores dos produtos das Empresas, os hábitos e costumes destes.

Com isso, pode-se acrescentar que as empresas que possuem um menor tempo de atividade no mercado externo estão mais preocupadas com a qualidade existente no produto ofertado do que as empresas que estão inseridas no mercado externo há mais tempo.

Isso leva a crer que, com o passar do tempo, os empresários investem menos em qualidade no produto/serviço, o que de certa forma pode tornar o seu produto ou serviço cada vez 
menos competitivo frente ao mercado internacional, que se torna cada vez mais concorrido, podendo assim desvalorizar seu produto e perder competitividade para as empresas mais recentes no cenário internacional, uma vez que o grande diferencial do mercado externo é qualidade.

A tabela 6, apresenta a correlação entre a dificuldade encontrada no plano de internacionalização da Empresa, com a participação desta na Balança Comercial.

Tabela 6: Correlação 4

\begin{tabular}{lc}
\hline \multicolumn{1}{c|}{ VARIÁVEIS } & CORRELAÇÃO \\
\hline Dificuldade Encontrada no Plano de Internacionalização & $-0,550$ \\
Participação na Balança Comercial do RN & \\
\hline
\end{tabular}

Fonte: Pesquisa de Opinião, 2009. Elaboração: a autora.

Como pode-se observa na tabela 6, a variável Dificuldade Encontrada pela Empresa ao montar o Plano de Internacionalização está inversamente correlacionada com a variável Participação na Balança Comercial do RN.

Vale ressaltar que, a dificuldade encontrada no Plano de Internacionalização, consiste na principal dificuldade encontrada pela empresa no plano de internacionalizar o produto a ser exportado, que são as opções: por que exportar, o que exportar, para onde exportar, para quem exportar ou como exportar.

Com isso, a tabela 15 permite analisar que, considerado o Coeficiente de Correlação Linear e sua variação, a principal dificuldade encontrada pela maioria das empresas, que foi para quem exportar, possuem uma participação na Balança Comercial que é Razoável, mas sem apresentar condições de melhoria. Ou seja, as maiores empresas exportadoras do Estado, sentem grande dificuldade em definir o potencial comprador de seus produtos e/ou serviços.

Pode-se concluir também que as Empresas que possuem uma participação pequena na Balança Comercial, mas que pode crescer rapidamente possui como principal dificuldade no plano de internacionalização, para onde exportar. Ou seja, as empresas entrevistadas que possuem uma menor participação na Balança Comercial, consideram como o maior impasse no plano de exportação do produto, conhecer os potenciais países importadores das mercadorias e/ou serviços que estas empresas visam oferecer.

\section{PRINCIPAIS RESULTADOS: SÍNTESE EXECUTIVA}

Com o objetivo de estudar o perfil das empresas exportadoras do Rio Grande do Norte, primeiramente delineou-se a população a ser estudada, que compreendia cento e vinte e duas empresas exportadoras. Porém, como seria inviável estudar toda a população, definiu- 
se uma amostra para que a pesquisa obtivesse um resultado satisfatório. Com isso, foram selecionadas, à priori, cinqüienta e nove empresas.

Há duas vantagens em escolher o método de amostragem. A primeira, é a de que há similaridade suficiente entre os elementos de uma população, de tal forma que uns poucos elementos, representarão adequadamente as características de toda a população; a segunda é a de que a discrepância entre os valores das variáveis na população, e os valores dessas variáveis obtidos na amostra são minimizados, pois, enquanto algumas medições subestimam o valor do parâmetro, outras superestimam.

Com o decorrer da pesquisa, observou-se que, entre essas cinqüenta e nove empresas, cinco empresas haviam fechado, e três exportavam por outro Estado. Logo, essas oito não faziam mais parte da pesquisa, uma vez que, o principal objetivo do trabalho era analisar empresas que exportam pelo Estado.

Como citado anteriormente, das cinqüenta e uma empresas previstas para entrevistar, apenas vinte responderam ao questionário. Então, o retorno dos questionários foi de $39,22 \%$, o que é considerada uma ótima taxa de retorno, pois, uma taxa de retorno é considerada significativa a partir de $20,9 \%$ de retorno.

Algumas das empresas que optaram por não auferir os questionários argumentaram que estão passando por processos de auditoria interna, e estão impossibilitadas de receberem os questionários; outras por afirmarem que os responsáveis da área estão viajando.

Em algumas outras empresas, os empresários argumentaram que para o recebimento do questionário teria que passar pelos diretores e presidentes da empresa, a fim de verificar o objetivo real da pesquisa.

Vale ressaltar que o não retorno dos questionários é muito importante para a pesquisa, uma vez que, isto nos permite analisar o perfil das empresas exportadoras do Estado, visto que estas não possuem interesse algum em pesquisas que possam favorecer o conhecimento e perfil dos empreendimentos da região; mostrando ainda que estas empresas não desejam contribuir diretamente com o desenvolvimento acadêmico de alunos que procuram de alguma forma aliar teoria e prática.

As empresas visitadas foram bastante receptivas e responderam ao questionário com escopo de colaborar com a pesquisadora bem como conhecer o mercado em que atuam. Todos os respondentes tiveram interesse em receber o trabalho pronto.

De acordo com a análise dos dados do referido trabalho, foi possível analisar o perfil das empresas exportadoras, como também o perfil dos empresários. Com isso, a presente pesquisa conseguiu atingir o objetivo inicial do projeto, que seria conhecer a base exportadora do Estado, e analisar a viabilidade de implantação de uma empresa de consultoria em Comércio Exterior.

Como foi apresentado nos figuras, anteriormente, grande parte das empresas exportadoras concentram-se na Região Administrativa Leste de Natal, no bairro da Ribeira, pela localização geográfica estratégica, e o acesso ao Porto de Natal.

Foi possível descobrir que a maioria dos gestores das Empresas exportadoras, possuem entre 21 e 40 anos, isso mostra a inserção de jovens cada vez mais preparados e em cargos 
de maior confiança da empresa, mais rapidamente. A maioria das empresas entrevistadas foi de médio porte, isso mostra que para ser empresa exportadora, não necessita necessariamente ser grandes Companhias.

Uma grande descoberta da pesquisa foi mostrar o escasso setor de serviços para a exportação. Nenhuma das Empresas entrevistadas exporta apenas serviços, e apenas $37,50 \%$ das Empresas entrevistadas agregam algum tipo de serviço aos produtos exportados. Esse cenário permite visualizar um mercado em potencial, pouco explorado pelas Empresas do RN, e que pode representar grande diferencial competitivo no Mercado Internacional.

Outro fator relevante para a pesquisa foi a estabilidade econômica que as Empresas do Estado apresentam. Pois, a maioria das Empresas que respondeu ao questionário, considera a atual conjuntura econômica como Regular ou Ótima, apenas 25\% das Empresas consideram Ruim. Em relação à situação econômica da Empresa em relação ao mercado, mais de $31 \%$ consideraram como Ótima, e 56\% como Regular. Apenas pouco mais de $12 \%$, consideram ruim a conjuntura econômica da Empresa.

Isso permite concluir que as Empresas do RN estão aptas a enfrentar as instabilidades do mercado e conseguir superar crises comerciais, com equilíbrio, pois, como apresentado nos figuras da pesquisa, a maioria das Empresas passa por situações de equilíbrio entre oferta e demanda, conseguindo vender tudo o que produzem.

A maior parte dos empreendimentos entrevistados, atuam no Mercado Internacional a mais de 5 anos, e de acordo com as correlações apresentadas na seção 7.3, quanto mais tempo as empresas estiveram inseridas no mercado, maios será a propensão dessas Empresas a investirem em qualidade. Logo, as Empresas que mais valorizam a qualidade, ao as empresas mais recentes atuantes no Cenário Internacional.

Um fator relevante a ser ressaltado aqui, é o alto número de Empresas entrevistadas estarem inseridas no Comércio Exterior por conta própria, e não utilizarem de nenhum programa de incentivo às exportações. Dessa forma, pode concluir que o governo está gastando dinheiro e tempo, investindo em programas sem retorno, e que não traz nenhum benefício à região. Talvez pela burocracia desses programas do governo que acabam desestimulando os empresários, e fazendo com que estes procurem um caminho mais rápido e fácil para comercializar os seus produtos, que é por iniciativa própria.

Para 50\% das Empresas entrevistadas, a participação na Balança Comercial destas, é Razoável, mas que ainda pode crescer rapidamente. Segundo as empresas entrevistadas, as principais dificuldades encontradas ao exportar é a oscilação cambial, o protecionismo por parte dos países importadores e da legislação vigente destes países. Mas, algumas Empresas citaram outros fatores que impedem ou dificultam o índice das exportações. Fatores como, acesso a crédito com juros compatíveis com a realidade econômica da empresa; Outras citaram como fator predominante os altos custos com logística, como também a carência de modais adequados para o transporte de determinados produtos. Outra barreira ao exportar é identificar o cliente, ou seja, o potencial importador da empresa.

Em relação ao Curso Superior de Tecnologia em Comércio Exterior do IFRN e as Empresas entrevistadas, observou-se que uma grande parte das empresas não sabia da 
existência do curso na Instituição de Ensino (37,50\%). E apenas 12,50\% das Empresas já haviam contratado algum aluno de Comércio Exterior. Embora, quase $90 \%$ considerem a Instituição de ensino como Ótima. Logo, esse cenário permite analisar que a baixa colocação dos alunos do Curso pode ser em partes explicado pela falta de divulgação do curso no RN, como também pela falta de parcerias junto às Empresas Exportadoras da região.

Já no âmbito de interesses em consultoria, a presente pesquisa objetivou analisar a necessidade por cinco cursos: Gestão de Negócios, Gestão de Pessoas, Análise de Mercado, Marketing e Atendimento ao Cliente. Dos cinco cursos analisados, e das respostas das Empresas entrevistadas, há demanda para todos os cursos. A consultoria que houve menor demanda foi de Atendimento ao Cliente, onde 37,50\% das Empresas não têm interesse neste tipo de consultoria. Isso pode ser explicado, visto que algumas das Empresas Exportadoras não trabalham diretamente com o cliente. Logo, pode-se concluir que há demanda por consultoria em Comércio Exterior pelas Empresas entrevistadas.

\section{CONCLUSÃO}

No que tange o cenário das Empresas Exportadoras do Estado do Rio Grande do Norte, objeto de estudo da presente monografia, pôde-se identificar o perfil dos gestores das Empresas, o cenário em que essas estão inclusas, avaliar a inserção dos alunos do Curso Superior de Tecnologia em Comércio Exterior do Instituto Federal de Educação, Ciências e Tecnologia do Rio Grande do Norte, como também estudar a necessidade de suporte e consultoria por essas Empresas Exportadoras.

Vale ressaltar que, para que a pesquisa fosse satisfatória, dentro da população a ser estudada no presente trabalho, que consistia em examinar as Empresas Exportadoras do Estado, que somavam cento e vinte e duas Empresas, foi delineada uma amostra, de cinqüenta e nove Empresas, à priori. Com o decorrer da pesquisa, esse número foi reduzido para cinqüienta e uma Empresas, mas dessas, somente vinte aceitaram responder ao questionário, o que possibilitou um retorno de $39,22 \%$.

Dessa forma, concluo esta monografia com a certeza de que diante da conjuntura econômica atual, onde o mundo passa por uma crise econômica mundial, as empresas do RN estão aptas a concorrer no mercado, que se torna cada vez mais competitivo, visto que apresentam situações economicamente equilibradas, e favoráveis ao Comércio Exterior.

Observou-se que grande parte das Empresas Exportadoras não tinha conhecimento do Curso de Comércio Exterior que o IFRN oferece, o que pode dificultar a inserção desses alunos no mercado exportador do RN. Pois, das Empresas entrevistadas apenas 12,50\% já haviam contratado alunos de COMEX.

Logo, conclui-se que para aumentar o índice de inserção dos alunos de Comércio Exterior no mercado exportador norte rio-grandense, é preciso que a Instituição de Ensino invista mais em programas e parcerias junto às Empresas Exportadoras do Estado, para permitir que os alunos do curso possam aliar teoria e prática, à medida que promovem os conhecimentos específicos para as Empresas. 
Com a pesquisa, também foi concluído que as Empresas Exportadoras do RN demandam por consultoria nas áreas inclusas na pesquisa: Gestão de Negócios, Gestão de Pessoas, Análise de Mercado, Marketing e Atendimento ao Cliente. Com isso, é viável sim, a implantação de uma empresa de Consultoria em Comércio Exterior, desde que, essa se utilize de estratégias pertinentes para conquistar o mercado das Companhias Exportadoras do Estado.

\section{REFERÊNCIAS BIBLIOGRÁFICAS}

1. AlEXANDRE, M. J. O. Construção do Trabalho Cientifico. São Paulo: Forense Universitari, 2003.

2. ALMEIDA, Alberto Carlos. Como são feitas as pesquisas eleitorais e de opinião. 2 ed. Rio de Janeiro: FGV, 2003.

3. Alice Web. 2009. Disponível em: <http://aliceweb.desenvolvimento.gov.br/>. Acesso em: 14 Jun 2009, 14:36.

4. ALUNOS de Comércio Exterior Participam do Projeto $1^{\circ}$ Exportação. 2008. Disponível em: <http://www.cefetrn.br/conteudo/noticias/alunos-de-comercio-exterior-docefet-rn-vao-participar-do-projeto-primeira-exportacao-convenio-sera-assinado-nestaquarta-durante-o-116b0-encomex-no-centro-de-convencoes/>. Acesso em: 4 Dez 2008, $18: 27$.

5. ALUNOS Protagonizam Projeto Piloto no RN para inserir Empresas no Ramo de Exportação. 2008. Disponível em: <http://www.cefetrn.br/conteudo/noticias/alunos-docefet-protagonizam-projeto-piloto-no-rn-para-inserir-empresas-no-ramo-da-exportacao/> . Acesso em: 01 Dez 2008, 18:40.

6. ASSESSORIA de Comunicação do Governo do RN. 2009. Disponível em: <http://www.assecom.rn.gov.br/notAnt.asp?idnoticia=5960>. Acesso em: 14 Jun 2009, $14: 30$.

7. CERTUS, Instituto Certus Pesquisa e Consultoria. Pesquisa de Opinião sobre a Eleição Municipal de Natal/RN em 2008. Natal: TRE/RN, 2008.

\section{CONSULT, Pesquisa. Pesquisa de Opinião sobre a Eleição Municipal de Natal/RN} em 2008. Natal: TRE/RN, 2008.

9. CRISE, de 2002 foi mais perigosa para o Brasil do que a atual. 2009. Disponível em: <http://www.correiobraziliense.com.br/html/sessao_1/2009/01/20/noticia_interna,id_sessa o=1\&id_noticia=68390/noticia_interna.shtml>. Acesso em: 13 Mai 2009, 19:40.

10. CRISE, Efeitos patrimoniais em crises cambiais: evidências da crise brasileira de 2002. 2003. Disponível em: <http://www2.dbd.pucrio.br/pergamum/tesesabertas/0212203_06_cap_02.pdf>. Acesso em: 13 Mai 2009, 20:00.

11. DANCEY, Christine P.; REIDY, John. Estatística sem Matemática Para Psicologia. 3 ed. Porto Alegre: Artmed, 2006. 
12. FECOMÉRCIO.

Disponível

em:

<http://www.fecomerciorn.com.br/navegacao/comercio.php>. Acesso em: 4 Dez2008, 17:50.

13. FONSECA, Jairo Simon da; MARTINS, Gilberto Andrade. Curso de Estatística. 6 ed. São Paulo: Atlas, 1996.

14. FURTADO, Milton Braga. Síntese da Economia Brasileira. 7 ed. Rio de Janeiro: Livros técnicos e Científicos, 2000.

15. GIL, Antonio Carlos. Como Elaborar Projetos de Pesquisa. 4 ed. São Paulo: Atlas, 2002.

16. JUNCKES, Neuza Maria. Método de Pesquisa. 1996. Disponível em <http://www.eps.ufsc.br/disserta98/neusa/cap4.htm>. Acesso em: 05 Jul 2009, 21:30.

17. PRADO JÚNIOR, Caio. História Econômica do Brasil. 43 ed. São Paulo: Brasiliense, 1998.

18. MAIA, Jayme de Mariz. Economia Internacional e Comércio Exterior. 11 ed. São Paulo: Editora Atlas, 2007.

19. MALHOTRA, Naresh K at al. Introdução à Pesquisa de Marketing. São Paulo: Prentice-Hall, 2005.

20. MATTAR, Fauze N. Pesquisa de Marketing. Edição Compacta. São Paulo: Atlas, 2006.

21. Brasil, Ministério de Educação. Portal do Governo Federal. 2008. Disponível em: $<$ http://portal.mec.gov.br/index2.php?option=com_content\&do_pdf=1\&id=9574>. Acesso em: 01 Dez 2008, 16:30.

22. Brasil, Ministério de Desenvolvimento, Indústria e Comércio. 2009. <http://www.mdic.gov.br/sitio/interna/interna.php?area=5\&menu=1444\&refr=603 >

Acesso em: 01 Dez 2008,14:00.

23. MILONE, Giuseppe. Estatística Geral e Aplicada. São Paulo: Pioneira Thomson Learning, 2004.

24. OLIVEIRA, Lúcia Maria Barbosa de; MORAES, Walter Fernando Araújo de. Coleta de Dados Realizada por Questionário Enviado pelo Correio: Método Eficaz?. Pernambuco: Universidade Federal de Pernambuco. Disponível em: <www.angrad.org.br>. Acesso em: 12 de Jul 2009, 15:00.

25. SAMARA, Beatriz; BARROS, José Carlos de. Pesquisa de Marketing. 4 ed. São Paulo: Prentice-Hall 2006.

26. SANDENBERG. Carlos Alberto. Entrevista com a Global 21. Publicada em 02 de Julho de 2007. Disponível em: 
<http://www.global21.com.br/entrevistas/entrevista.asp?cod=294>. Acesso em: $04 \mathrm{Jul}$ 2009, 10:30.

27. SILVA, Elieser Baptista da; HUKAY, Roberto Y. Jornal O Estado de São Paulo. São Paulo: 25 Nov 2006.

28. TRIOLA, Mario F. Introdução a Estatística. 7 ed. Rio de Janeiro: Livros Técnicos e Científicos, 1998.

29. VAZQUEZ, José Lopes. Comércio Exterior Brasileiro. 5 ed. São Paulo: Atlas, 2001. 